九州大学学術情報リポジトリ

Kyushu University Institutional Repository

\title{
Lower Cretaceous Marine Pelecypods of Japan Part II
}

Hayami, Itaru

Faculty of Science, Kyushu University

https://doi.org/10.5109/1543636

出版情報：九州大學理學部紀要：Series D, Geology. 17 (2)，pp.73-150，1965-12-20. Faculty of Science, Kyushu University バージョン：

権利関係 : 
Mem. Fac. Sci., Kyushu Univ., Ser. D, Geology, Vol. XVII, No. 2, pp. 73-150, table 1, pls. 7-21, December 20, 1965

\title{
Lower Cretaceous Marine Pelecypods of Japan
}

\section{Part II}

\author{
By
}

\author{
Itaru HAYAMI
}

\begin{abstract}
This is a serial comprehensive study on the Lower Cretaceous pelecypods of Japan, except for the trigoniids, the pachyodonts and the brackish- and fresh-water species. In the present part 44 species of the Heterodontida are described systematically on the basis of numerous specimens which were collected from various sedimentary areas by many stratigraphers and palaeontologists including myself. A new subfamily, Eomiodontinae, two new genera, Costocyrena and Nagaoella, three new subgenera, Yabea, Miyakoella and Globocardium, and 11 new species are proposed.
\end{abstract}

\section{Contents}

4. Systematic descriptions (continued from Part I) $\ldots \ldots \ldots \ldots \ldots .75$

Order Heterodontida ................................. 75

Suborder Astartedontina ............................. 75

Superfamily Carditacea $\ldots \ldots \ldots \ldots \ldots \ldots \ldots \ldots \ldots \ldots \ldots \ldots, 75$

Family Myoconchidae .......................... 75

Genus Myoconcha SowerBy, 1824 ................. 75

Myoconcha modesta sp. nov....................... 76

Family Carditidae ............................. 77

Genus Pseudocardia ConRad, 1866 ................. 77

Pseudocardia sp. cf. P. tenuicosta (Sowerby) ......... 77

Pseudocardia amanoi sp. nov. ................... 79

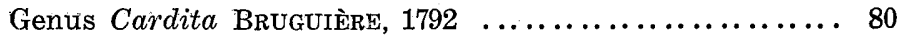

"Cardita" ? sp. indet. ......................... 80

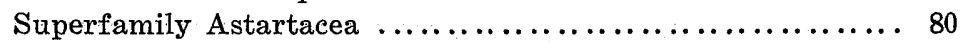

Family Astartidae .............................. 80

Subfamily Astartinae...................... 80

Genus Astarte Sowerby, $1816 \ldots \ldots \ldots \ldots \ldots \ldots \ldots \ldots . .60$

Subgenus Astarte s. str. ...................... 81

Astarte (Astarte) subsenecta $\mathrm{Y}_{\mathrm{ABE}}$ and NAGAO ....... 81

Astarte (Astarte) sp. ef. A. (A.) subsenecta

YABE and NAGAO ....................... 84

Astarte (Astarte) costata $\mathrm{YABE}$ and NAGAO ......... 85

Received August 25, 1965.

Continued from Part I (Mem. Fac. Sci., Kyushu Univ., Ser. D, Vol. XV, No. 2, pp. 221-349, text-figs. 1-4, pls. 27-52, March 1, 1965), which includes the introductory notes and the systematic description of the species belonging to the Palaeotaxodontida, Eutaxodontida, Isofilibranchida, Pteroconchida and Colloconchida. The forthcoming Part III of this study will include the description of the species of Asthenodontida and Eudesmodontida, the conclusion on the fauna, the locality guide and the bibliography. 
Astarte (Astarte) semicostata NAGAo .......... 86

Astarte (Astarte?) sp. indet.................. 88

Subgenus Freiastarte CHAVAN, 1952 .............. 88

Astarte (Freiastarte) subomalioides NAGAo .......... 88

Astarte (Freiastarte) sp. cf. A. (F.) subomalioides

NAGAO $\ldots \ldots \ldots \ldots \ldots \ldots \ldots \ldots \ldots \ldots \ldots \ldots \ldots \ldots . \ldots$

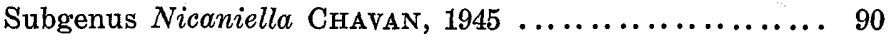

Astarte (Nicaniella) minor NAGAo ............... 91

Subgenus Yabea nov........................ 92

Astarte (Yabea) shinanoensis YABE and NAGAo ....... 93

Astarte (Yabea) sp. aff. A. (Y.) shinanoensis

YABE and NAGAo ...................... 94

Astarte (Yabea) akatsui sp. nov. .............. 95

Subfamily Eriphylinae........................ 96

Genus Eriphyla GABB, 1864 ................. 96

Subgenus Eriphyla s. str.................... 97

Eriphyla (Eriphyla) pulchella sp. nov. ............ 98

Eriphyla (Eriphyla) minima sp. nov. ............ 99

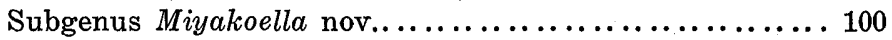

Eriphyla (Miyakoella) miyakoensis (NAGAo).......... 101

Eriphyla (Miyakoella) sp. ef. $E$. (M.) miyakoensis

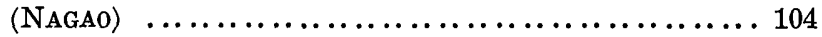

Subfamily Opisinae $\ldots \ldots \ldots \ldots \ldots \ldots \ldots \ldots \ldots \ldots \ldots \ldots \ldots \ldots$

Genus Opis Defrance, 1825 ...................... 104

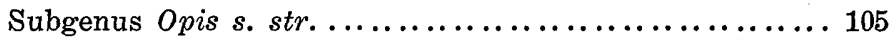

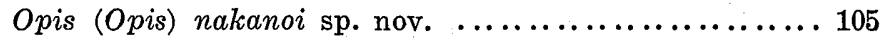

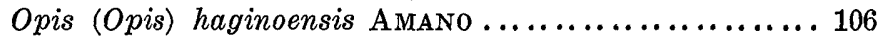

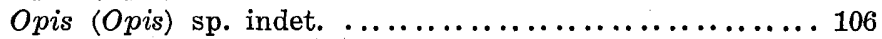

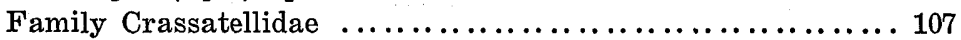

Subfamily Crassatellinae......................... 107

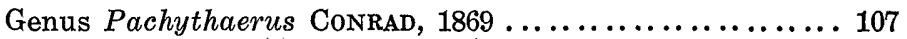

Pachythaerus kagaharensis (Yokoyama) ......... 107

Subfamily Scambulinae ....................... 109

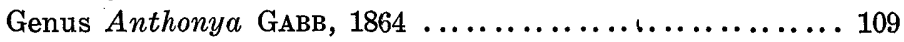

Anthonya subcantiana NAGAo ................ 110

Anthonya sp. aff. A. subcantiana NAGAo .......... 113

Suborder Oligodontina .......................... 113

Superfamily Lucinacea $\ldots \ldots \ldots \ldots \ldots \ldots \ldots \ldots \ldots \ldots \ldots \ldots \ldots \ldots$

Family Lucinidae ............................ 113

Genus Lucinoma DALL, 1901 ..................... 113

Lucinoma (?) kotoi (NAGAo) ................. 113

Lucinoma (?) sp. indet. .................... 114

Family Fimbriidae............................ 115

Genus Fimbria MegerLe, $1811 \ldots \ldots \ldots \ldots \ldots \ldots \ldots \ldots \ldots \ldots$

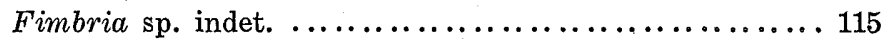

Superfamily Cardiacea $\ldots \ldots \ldots \ldots \ldots \ldots \ldots \ldots \ldots \ldots \ldots \ldots \ldots \ldots \ldots$

Family Cardiidae............................ 116

Subfamily Protocardiinae $\ldots \ldots \ldots \ldots \ldots \ldots \ldots \ldots \ldots \ldots \ldots \ldots$

Genus Protocardia BEYRICH, 1845 ............... 116

Subgenus Globocardium nov. ................ 116

Protocardia (Globocardium) sphaeroidea (FonBEs) ... 117

Subgenus indet. ........................... 119

Protocardia hiraigensis sp. nov. ................ 119 
Genus Nemocardium MeEK, $1876 \ldots \ldots \ldots \ldots \ldots \ldots \ldots \ldots \ldots$

Nemocardium yatsushiroense sp. nov. ............ 120

Subfamily Laevicardiinae ..................... 123

Genus Laevicardium SwaINson, $1840 \ldots \ldots \ldots \ldots \ldots \ldots . \ldots 123$

Laevicardium (?) ishidoense (YABE and NAGAO) ...... 123

Laevicardium (?) corpulentum (AMANo) ............ 125

?Superfamily Tellinacea......................... 126

Family Icanotiidae .......................... 126

Genus Scittila CASEY, $1961 \ldots \ldots \ldots \ldots \ldots \ldots \ldots \ldots \ldots \ldots \ldots$

Scittila japonica sp. nov................... 126

Scittila sp. indet.......................... 127

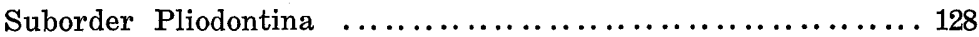

?Superfamily Arcticacea . . . . . . . . . . . . . . . 128

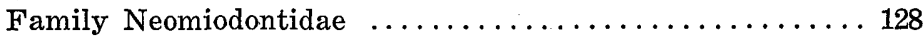

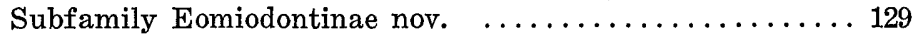

Genus Costocyrena nov. ..................... 130

Costocyrena matsumotoi sp. nov. ............. 133

Costocyrena radiatostriata (YABE and NAGAO) ...... 135

Costocyrena sp. aff. C. radiatostriata (YABE and NAGAO) 137

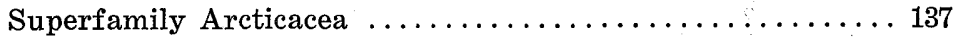

Family Arcticidae ..................... 137

Genus Isocyprina RoEDER, $1882 \ldots \ldots \ldots \ldots \ldots \ldots \ldots \ldots$

Isocyprina aliquantula (AMANo) ............ 137

Genus Veniella StouIczKa, $1871 \ldots \ldots \ldots \ldots \ldots \ldots \ldots \ldots$

$V$ eniella sp. aff. $V$. japonica NAGAo . . . . . . . 139

?Superfamily Veneracea $\ldots \ldots \ldots \ldots \ldots \ldots \ldots \ldots \ldots \ldots \ldots \ldots$

?Family Veneridae ..................... 139

Genus Ptychomya Agassiz, 1845 .............. 139

Ptychomya densicostata NAGAo . . .......... 141

Superfamily Veneracea .................... 144

Family Veneridae . . . . . . . . . . . . . . . . . . 144

Genus Agapella Vokes, $1946 \ldots \ldots \ldots \ldots \ldots \ldots \ldots \ldots$

Agapella (?) koikorobensis sp. nov. ........... 144

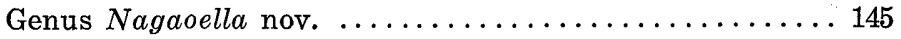

Nagaoella corrugata (NAGAo) . . . . . . . . . 148

Nagaoella sp. aff. N. corrugata (NAGAO) $\ldots \ldots \ldots \ldots 150$

\section{Systematic Descriptions [continued from Part I]}

Order Heterodontida

Suborder Astartedontina

Superfamily Carditacea

Family Myoconchidae

Genus Myoconcha Sowerby, 1824

Type-species.-Myoconcha crassa SOWERBY, 1824, Middle Jurassic, England (monotypy).

Remarks.-Myoconcha (=Labayaphorus LichaRew, 1939) ranged from Middle Permian to Cretaceous (NeweLL, 1957). Formerly some authors referred this genus to the Mytilacea or Modiolopsidae chiefly on the basis of the external resemblance. Chavan (1954) showed that Permophorus Chavan, 1954 
(=Pleurophorus KING, 1848, non MUlSANT, 1842), Triaphorus Marwick, 1953, and Kalentera MARWICK, 1953, are regarded as the members of the Carditacea. In fact, Myoconcha should be placed in the Carditacea together with those genera, because the disposition of the posterior lateral teeth and myophoric buttress behind the anterior adductor scar are very similar to those of the Carditidae and the Permophoridae. NewELl (1957) studied the hinge structure of the Palaeozoic and Mesozoic species of this primitive heterodont group, proposing the Myoconchidae which include Stutchburia ETHERIDGE Jr., 1900, and Netchajewia JAKOLEW, 1925, in addition to Myoconcha. This procedure is adopted here. The hinge of typical Myoconcha is composed of one elongated subumbonal tooth in the right valve and isolated posterior lateral teeth in each valve, being generally formulated $\frac{3 b \text { PI PIII }}{\text { PII }}$. It is quite different from the dentition of the Mytilidae and the Modiolopsidae, which can be by no means expressed with BERNARD's notation.

\section{Myoconcha modesta sp. nov.}

Plate 13, Figure 1

Material.-The holotype is a left valve (GK. $\mathrm{H} \mathrm{6391)}$ ) collected from the Tanohata formation at loc. Hn. 0803, Koikorobe, Tanohata village, Shimohei County, Iwate Prefecture (HAYAMI coll.).

Description.-Shell comparatively small, mytiliform, elongated and expanded posteriorly, much longer than high, not strongly inflated; test fairly thick; maximum height lies at about two-thirds of shell-length from the anterior extremity; antero-ventral margin straight, long, forming a rounded obtuse angle with the posterior margin; umbo terminal, not prominent; ligament opisthodetic, external, elongated along the dorsal margin; surface apparently smooth except for fine concentric growth-lamellae; radial ribs not observed; left valve provided with a linearly elongated subhorizontal cardinal socket $3 \mathrm{~b}^{\prime}$ and a remote well-defined posterior lateral tooth PII; $2 \mathrm{~b}$ and $4 \mathrm{~b}$ not delimited; anterior adductor scar strongly impressed, subovate in outline, delimited upwards by the elevated nymph and backwards by a strong myophoric buttress; posterior adductor scar impressed obscurely; ventral margin apparently smooth internally. Holotype (GK. H 6391) left valve, $52.0 \mathrm{~mm}$. long, $30.5 \mathrm{~mm}$. high, $7.5 \mathrm{~mm}$. thick.

Observations and comparisons.-The present species is represented only by a left valve which reveals dentition and other internal characters. The exterior of the specimen was water-worn probably before the fossilization, but the terminal position of the umbo is recognized from the faintly impressed growth-lines.

In the outline the present species resembles Netschajewia from the Permian, but the terminal umbo and horizontally elongated cardinal tooth $3 \mathrm{~b}$ indicate that it should be included in Myoconcha. It differs from Myoconcha cretacea D'ORBIGNY, 1844, from the Cenomanian of France and from the Upper Greensand of England (WooDs, 1901) in the more strongly convex post-umbonal margin and nearly straight antero-ventral margin. It is distinguishable from Myo- 
concha transatlantica BURCKHARDT, 1903, from the Neocomian of Argentina (WEAVER, 1931), and from Myoconcha angulata D'ORBIGNY, 1844, from the Neocomian of France in the absence of diagonal carina and probably thinner test, although the outline is fairly similar. Myoconcha delta CASEY, 1961, from the Lower Greensand of England, has a terminal umbo, more rounded posterior end and smaller dimensions than the present species.

Occurrence.-Lower Miyakoan (Aptian). Conglomeratic sandstone of the Tanohata formation at loc. Hn. 0803, Koikorobe, Tanohata village, Shimohei County, Iwate Prefecture:

\section{Family Carditidae \\ Genus Pseudocardia CoNRAD, 1866 \\ (=Vetocardia ConRad, 1868; Vetricardia ConRad, 1872)}

Type-species.-Venericardia dupiniana D’ORBIGNY, 1844, Cretaceous, Europe (designated by SToLICZKA, 1871).

Remarks.-A number of Cretaceous carditids show subquadrate outline, narrow radial ribs and undeveloped lateral teeth, and seem to constitute a certain taxonomic group in the Carditidae, for which Pseudocardia ConRad, 1866, is applicable. SToLiczKa (1871) and Cox (1946), who cited the name of Pseudocardia, regarded it as a synonym of Venericardia. However, the outline of Pseudocardia is more quadrate and the radial ribs are finer and more scaly than in Venericardia. Some species of Glans MEgerLe VoN MÜHLFELD, 1811 (type-species: Chama trapezia Linnaeus, 1767), from the Cenozoic, have similarly scaly ribs, but the anterior and posterior lateral teeth are more distinct in that genus. The external features of Pseudocardia are somewhat similar also to some species of Tutcheria Cox, 1946, from the Lower Jurassic (? and Triassic), but the latter genus has more Astarte-like cardinal teeth and better developed lateral teeth.

\section{Pseudocardia sp. cf. P. tenuicosta (SowERBY) \\ Plate 7, Figures 1-3}

Compare.-

1836. Venericardia tenuicosta Sowerby, Trans. Geol. Soc., Ser. 2, Vol. 4, pp. 114, 259, 356, pl. 11, fig. 7 .

1842. Venericardia tenuicosta, LeYMenIE, Mém. Soc. géol. France, Sér. 2, Tom. 5, p. 25, pl. 3, fig. 9 .

1844. Cardita tenuicosta, D’ORBIGNy, Pal. franç., Terrain crétacé, Vol. 3, p. 87, pl. 268, figs. 11-13.

1900. Cardita tenuicosta, Wollemann, Abhandl. k. preuss. geol. Landes., N. F., Nr. 31, p. 94, pl. 4, fig. 9 .

1906. Cardita tenuicosta, Woods, Monogr. Cret. Lamell. England, Vol. 2, p. 124, pl. 18, figs. 7-14.

1961. Pseudocardia tenuicosta, CASEY, Palaeontology, Vol. 3, p. 606, listed.

Material.-Three specimens (GK. H 6392-GK. H 6394) from the Miyako area (HANAI coll.) are concerned with the description below. 
Description.-Shell of medium size for the genus, subquadrate in outline, highly inequilateral, much longer than high, moderately inflated but somewhat flattened in the postero-dorsal peripheral area; antero-dorsal margin short, straight; postero-dorsal margin much longer, nearly straight, forming an angle of approximately 100 degrees with the antero-dorsal margin; posterior margin subvertical, weakly convex; ventral margin well rounded, defined from the antero-dorsal and posterior margins respectively by strong curvature; umbo prosogyrous, placed anteriorly, slightly rising above the dorsal margin; a blunt rounded carina extends diagonally from the umbo to the postero-ventral corner; lunule hemispherical, fairly deep, nearly smooth; escutcheon delimited by a sharp ridge, elongated along the postero-dorsal margin; surface ornamented with about 50 radial ribs which are somewhat irregular in prominence but generally much narrower than their interspaces and become finer towards the posterior area; numerous concentric lines cross radials, forming small scales at the intersections; ventral margin crenulated internally in accordance with the external radials; hinge and musculature unknown.

Measurements in $\mathrm{mm}$.

$\begin{array}{ccccc}\text { Specimen } & \text { Length } & \text { Height } & \text { Thickness } & \text { L/H } \\ \text { Both valves (GK.H6392) } & 21.0 & 19.5 & 13.0+ & 1.08 \\ \text { Right valve (GK.H6394) } & 19.5 & 17.5 & 6.0 & 1.11\end{array}$

Observations and comparisons.-This species is at present represented by three specimens from the Miyako group, one of which is an internal mould. The bivalved specimen (GK. H 6392) is strongly deformed, but the inner ventral crenulation and the deep lunule are well exposed. The right valve (GK.H 6394) probably shows the original outline, although the test is exfoliated in the umbonal region. In the latter specimen the postero-dorsal area, delimited by a weak carina, is further divided subequally into two parts by a median rib, which is more conspicuous than other ribs. It cannot be considered as a specific character, since such a median rib is obscure in other specimens.

It is noticed, however, that a similar median rib is also known in some specimens of Cardita tenuicosta (SOWERBY) from the Upper Greensand of England (Woods, 1906, pl. 18, fig. 11, etc.). The subquadrate outline and ornamentation are also very similar to those of $C$. tenuicosta, and, therefore, these specimens seem to be, if not identical with, closely related to the European species. Cardita constantii D'ORBIGNY, 1844 and Cardita rotundata PICTET and Roux, 1852, are also similar to the present species in the external features. In the subterminal position of umbo the present specimens may be closer to $C$. rotundata than to $C$. tenuicosta. The specific distinction of $C$. constantii and $C$. rotundata from $C$. tenuicosta is, however, not always clear, as CASEY (1961, p. 606) treated them as "varieties of C. tenuicosta". In this paper the present specimens are provisionally compared with $C$. tenuicosta.

Occurrence.-Lower Miyakoan (Aptian). Dark grey mudstone of the 1st cycle sediments of the Miyako group at loc. Hn. 2058, Hideshima of Sakiyama, Miyako City, Iwate Prefecture. 
Pseudocardia amanoi sp. nov.

Plate 7, Figures 4-7; Plate 15, Figures 1, 2

1957. Cardita (?) sp., Amano, Kumamoto Jour. Sci., Ser. B, Sec. 1, Vol. 2, No. 2 , p. 98 , pl. 2, figs. $27-29$, text-fig. 2 .

Material.-The holotype is external and internal moulds of a left valve (GK. H 6777) collected from the Hagino formation at loc. Hy. 6011, Hagino, Mirafu village, Kami County, Kochi Prefecture (OGAWA coll.). Paratypes (GK. H 6396-GK. H 6399, GK. H 6778-GK. H 6780) from the same locality (OGAWA coll.).

Description.-Shell very small, scarcely exceeding $9 \mathrm{~mm}$. in maximum length, inequilateral, roundly subquadrate in outline, nearly as long as high or a little longer than high, strongly inflated; antero-dorsal margin slightly concave in front of umbo; postero-dorsal one nearly straight; ventral margin broadly arcuate, but sometimes strongly curved near the mid-point; umbo prosogyrous, prominent, strongly incurved, placed at about one-third of length from the anterior extremity; carina not developed; lunule small, clearly impressed; surface ornamented with about 20 radial ribs which are almost regular and distinctly narrower than their interspaces; concentric lines very regular, forming a network with the radials; small spines formed at the intersections; ventral margin coarsely crenulated internally in accordance with the radial ribs; dentition as formulated: $\frac{(3 a) 3 b \quad \text { PIII }}{24 b \text { PII }} 2$ very small; $3 b$ subtrigonal, stout; $4 \mathrm{~b}$ narrowly elongated, subparallel to the dorsal margin; anterior lateral teeth undeveloped; PII and PIII very weak; adductor scars suboval, comparatively small; pallial line simple, running closely to the ventral margin.

Measurements in $\mathrm{mm}$.

Specimen

Holotype (GK.H6777) left in. mould

Paratype (GK.H6778) left ex. mould

Paratype (GK.H6779) right ex. mould

Paratype (GK.H6780) left in. mould

Paratype (GK.H6396) left in. mould

Paratype (GK.H6397) left in. mould

Paratype (GK.H6398) left ex. mould

Paratype (GK.H6399) left in. mould

$\begin{array}{cccl}\text { Length } & \text { Height } & \text { Thickness } & \text { L/H } \\ 8.5 & 8.0 & 4.5 & 1.06 \\ 8.0+ & 8.0 & 4.0 & 1.00+ \\ 7.0+ & 8.0 & ? & 0.88+ \\ 7.5 & 7.0 & 4.0 & 1.07 \\ 8.0 & 7.5 & 4.0 & 1.07 \\ 6.0 & 5.5 & 3.0 & 1.09 \\ 4.5 & 4.5 & 2.5 & 1.00 \\ 5.5 & 5.5 & 3.0 & 1.00\end{array}$

Observations and comparisons.-All the specimens are external and/or internal moulds, and their tests are completely eroded away. The spinose radial ribs are observed in the holotype and other external moulds. The hinge structure is not clearly observed in the holotype, but is revealed in a left internal mould (GK. H 6397). The disposition of the cardinal teeth and weak lateral teeth agree well with those of Cardita (?) sp. of AMANo (1957) from the same locality.

The present species is characterized by the relatively tall and strongly inflated shell, the absence of distinct anterior lateral teeth, the prominent umbo, 
the spinose radials and the regularly spaced concentrics. In these respects it may be close to Cardita cottaldina D'ORBIGNY, 1844, from the Upper Greensand of England (Woops, 1906), but it is distinguishable from the European species by the much smaller size and fewer radial ribs. The spinose radial ribs are somewhat similar to those of some Cenozoic and Recent species of Glans, such as Glans millegrana (NomURA and JIMBo), but the anterior lateral teeth are more clearly delimited from the cardinal teeth in the species of Glans.

The specific name is dedicated to Prof. Dr. Masahisa Amano of the Kumamoto University, who formerly described some specimens of this species from the same locality as the present material.

Occurrence.-Lower Miyakoan (Aptian). Fine weathered sandstone of the Hagino formation at loc. Hy. 6011, Hagino, Mirafu village, Kami County, Kochi Prefecture.

Genus Cardita BRUGuiÈRe, 1792

Type-species.-Cardita variegata BRUGUIÈRE, 1792, Recent (designated by Fleming, 1818).

"Cardita" (?) sp. indet.

Plate 7, Figure 8

A poorly preserved specimen (GK. $\mathrm{H} 6395$, right internal mould, $18.5 \mathrm{~mm}$. long, $22.0 \mathrm{~mm}$. high) is available for study. The test is completely eroded away, but the radial ornamentation with weak granules is clearly impressed on the internal mould. The outline and ornamentation remind me of those of some species of the Carditidae, although the generic reference cannot be decided at present. It differs evidently from the coexistent specimens of Pseudocardia sp. cf. $P$. tenuicosta (SOWERBY) in the much taller outline, more prominent umbo and fewer radial ribs. It is not impossible that the present specimen might represent a strongly deformed right valve of Pholadomya miyamotoi NAGA0, 1943, because the granulated radial ribs are somewhat similar.

Occurrence.-Lower Miyakoan (Aptian). Dark grey mudstone of the 1st cycle sediments of the Miyako group at loc. Hn. 2058, Hideshima of Sakiyama, Miyako City, Iwate Prefecture (HANAI coll.).

\author{
Superfamily Astartacea \\ Family Astartidae \\ Subfamily Astartinae \\ Genus Astarte SowERBY, 1816 \\ (=Crassina LAMARCK, 1817)
}

Type-species.-Astarte lurida SowerbY, 1816, Middle Jurassic, Europe (designated by SToliczKa, 1871).

Remarks.--The genus Astarte, which was one of the main trunks of the Astartidae, ranges from the Upper Triassic to the Recent, and its maximum development is found in the Middle-Upper Jurassic and Lower Cretaceous. 
Recent species of Astarte are living mainly in the cold seas, but in the Mesozoic times its distribution was not so restricted.

A number of Jurassic and Cretaceous brackish-water species with somewhat similar external features have been referred to Astarte, but they are mostly included in the Neomiodontidae in up-to-date classification.

The subdivision of Astarte into subgenera has been based on the hinge structure, shell size, surface ornamentation and ventral crenulation. In the present memoir CHAVAN's (1945, 1952) classification is adopted with slight modifications for the Lower Cretaceous species from Japan.

In Astarte (s. s.) the cardinal tooth $3 \mathrm{a}$ is well demarcated, and $5 \mathrm{~b}$ may or may not be developed. The shell-size of Astarte (s. s.) is commonly medium or small for the genus. The concentric sculpture is fairly variable in prominence, but usually becomes weaker towards the ventral periphery. In other subgenera concentric ribs, if present, are more persistent and almost equally prominent throughout the growth.

Tridonta Schumacher, 1817 (type-species: Tridonta borealis SCHMACHER, 1817) is said to be distinguishable from Astarte (s. s.) by the non-crenulated inner ventral margin (HABE, 1951).

Neocrassina FIScheR, 1887, was regarded by some authors as a synonym of Astarte (s. s.), but CHAVAN (1945) proposed to revive it as a subgenus of Astarte, distinguishing it from Astarte (s. s.) by the weaker anterior lateral teeth, more elongated posterior lateral teeth and more persistent concentric sculpture. The dimensions are generally much larger than in Astarte (s. s.)

The subgenus Nicaniella CHAVAN, 1945, is characterized by the absence of 3a, subovate outline and prominent, subequidistant and persistent concentric sculpture. The dimensions are always small for Astarte: The maximum length scarcely exceeds $10 \mathrm{~mm}$. The subgenus Freiastarte CHAvaN, 1952, resembles Nicaniella in the hinge structure and small size, but is distinguishable from the latter by the weaker shell convexity, more quadrate outline, and more sharply delimited lunule and escutcheon.

Above mentioned subgenera of Astarte, except for Neocrassina and Tridonta, are represented respectively by one or more species in the Lower Cretaceous faunas of Japan. Furthermore, Astarte shinanoensis YABE and NAGAo, 1926, is considered to constitute a new subgenus here named Yabea together with some other species. This subgenus is characterized by the Astarte (s. s.)-like dentition, i.e. the presence of $3 \mathrm{~b}$ and $5 \mathrm{~b}$, highly elevated cardinal teeth, unusually anterior placed and prosogyrous umbo and strong shell-convexity.

Subgenus Astarte s. str.

Astarte (Astarte) subsenecta YABE and NAGAO

Plate 7, Figures 10-18; Plate 14, Figures 1-5

1926. Astarte subsenecta YABE and NAGAo, in YABE, NAGAo and SHImizu, Sci. Rep. Tohoku Imp. Univ., Ser. 2, Vol. 9, Pt. 3, p. 47, pl. 13, fig. 16, pl. 14, fig. 11 (? pl. 13, figs. 14, 15; non pl. 14, fig. 10). 
1954. Astarte subsenecta, Matsumoto, Cret. System, Japan. Islands, pp. 64, 113, 115, listed.

Material.-Several specimens from the Sanchu area were described by YABE and NAGAO as Astarte subsenecta, but they are polymorphic. Two specimens (YABE, NAGAo and SHImizu, 1926, pl. 13, fig. 16, pl. 14, fig. 11) have subovate outline, while two other specimens (pl. 13, figs. 14, 15) are subtrapezoidal and seem at a glance to belong to another species. The original description coincides well with the former two specimens, of which a right external mould (YABE, NAGAO and SHImizu, 1926, pl. 14, fig. 11) is designated here as the lectotype. Another left external mould (pl.14, fig.10), which was named Astarte subsenecta var. costata, has distinctly weaker convexity, many persistent concentric ribs almost on the whole surface and is considered to be specifically distinct from the lectotype of $A$. subsenecta (see page 85). In addition to the lectotype, two specimens (GK. H 6166, GK. H 6177) from the Yatsushiro area (KANMERA coll.), 13 specimens (GK. H 6401-GK. H 6406, GK. H 6648GK. H 6651, GK. H 6793-GK. H 6795) from the Sanchu area (ICHIKAWA and HAYAMI coll.) and a specimen (GK. H 6773) from the Nozu area (FUJII coll.) are concerned with the description below.

Description.-Shell small to medium for the genus, scarcely exceeding $25 \mathrm{~mm}$. in length, inequilateral, variable in outline but usually subovate, moderately inflated, more or less longer than high; antero-dorsal margin nearly straight or a little concave; postero-dorsal margin much longer than the anterodorsal, gently arcuate; posterior margin truncated subvertically, defined from the postero-dorsal and ventral margins by obtuse angles; posterior area commonly delimited from the disk by an obscure carina; umbo prosogyrous, not very prominent, placed at about one-third or two-fifths of shell-length from the anterior end, unusually broad, scarcely rising above the dorsal margin; lunule narrow but fairly deep; escutcheon narrow, weakly delimited by a ridge; hinge plate broad; dentition of Astarte (s. s.) type, although the cardinal tooth $5 \mathrm{~b}$ is not clearly demarcated, being formulated: $\frac{\text { AI } 3 \mathrm{a} 3 \mathrm{~b} \text { (PIII) }}{\text { AII } 24 \mathrm{~b} \text { (PII) }}$; cardinal teeth divergent from the beak, flattened at the tops, subtriangular; 2 and $3 \mathrm{~b}$ stout; $3 \mathrm{a}$ and $4 \mathrm{~b}$ rather thin; lateral slopes of the cardinal teeth transversely striated; anterior lateral teeth AI and AII fairly stout, while posterior isolated laterals very weak and sometimes imperceptable; ventral margin finely crenulated internally, although it is nearly smooth in immature specimens; adductor scars subequal in size, subovate, strongly impressed; a small pedal scar clearly impressed behind the anterior adductor; umbonal cavity very shallow; surface marked wholly with numerous fine concentric lines of growth; a few broad concentric ribs distributed on the umbonal and middle surface, becoming much weaker towards the ventral margin. 
Measurements in $\mathrm{mm}$.

$\quad$ Specimen
Right valve (GK.H6401)
Right valve (GK.H6402)
Left in. mould (GK.H6403)
Left in. mould (GK.H6404)
Left ex. mould (GK.H6405)
Right in mould (GK.H6406)
Left in. mould (GK.H6648)
Left in. mould (GK.H6649)
Right in. mould (GK.H6650)
Right in. mould (GK.H6651)
Right in. mould (GK.H6166)
Left in. mould (GK.H6177)
Right valve (GK.H6773)

$\begin{array}{cccc}\text { Length } & \text { Height } & \text { Thickness } & \text { L/H } \\ 21.0 & 18.5 & 5.5 & 1.14 \\ 20.0 & 18.5 & 5.0 & 1.08 \\ 23.0 & 20.0 & 4.5 & 1.15 \\ 19.0 & 16.5 & 3.5 & 1.15 \\ 20.5 & 20.0 & 5.0 & 1.03 \\ 20.0 & 20.0 & 4.5 & 1.00 \\ 21.5 & 19.0 & 5.5 & 1.13 \\ 21.0 & 17.5 & 5.5 & 1.20 \\ 20.0 & 18.0 & 5.0 & 1.11 \\ 18.0 & 15.5 & 4.0 & 1.16 \\ 2 \mathrm{I} .0 & 19.5 & 3.5 & 1.08 \\ 19.5 & 17.5 & 3.0 & 1.11 \\ 21.5 & 21.0 & 5.5 & 1.02\end{array}$

Observations and comparisons.-Although the present specimens show quite variable outline, ornamentation and position of umbo, all the examined ones above measured seem to be conspecific with the lectotype of Astarte subsenecta YABE and NAGA0, 1926, from the Ishido formation of the Sanchu area. The posterior margin is very characteristically truncated in the present species. The ventral crenulations are fairly irregular in interval, but in many specimens they are most coarsely spaced in the postero-ventral portion and become more or less finer towards both sides. The ratio of length/height varies from 1.00 to 1.20 , as shown in the measurements. It is partly due to the secondary deformation but mostly attributable to the intraspecific variation. The persistence of the concentric ribs is also somewhat variable as shown in the plate. A specimen from the Haidateyama formation (GK. $\mathrm{H} \mathrm{6773)} \mathrm{has} \mathrm{more} \mathrm{regular}$ and more persistent concentrics than many specimens from the Sanchu area, but the difference may not be more significant than subspecific.

It should be noticed that there are weak transverse striae on the side walls of the cardinal teeth in the present specimens. However, similar striae are found in some Recent species of Astarte (s. s.), although the character has not been recorded in the type-species.

YABE and NAGAO compared the present species with Astarte senecta Woods, 1906, from the Speeton Clay of England, and noted that the former is distinguishable from the latter by the more compressed shell, less arcuate posterodorsal margin and more sharply truncated posterior margin. These differences except the last character cannot be always ascertained in the present material, and yet the present species is distinguishable from $A$. senecta by the less prominent umbo, less persistent concentric ribs, better defined posterior margin and somewhat finer ventral crenulations.

Astarte adkinsi Stoyanow, 1949, from the Lower Cretaceous of Arizona, shows similar ornaments and marginal crenulation, but its posterior area is not so clearly delimited and the ratio of length/height distinctly larger than in $A$. subsenecta. The present species is unexpectedly similar to Astarte 
higoensis TAMURA, 1959, from the Upper Jurassic Sakamoto formation of the Yatsushiro area of Kyushu especially in the shallow umbonal cavity and subovate outline, but the umbonal concentric ribs are indistinct and the anterior lateral teeth' are less clearly demarcated in that species.

The ornamentation of the present species may be remniscent of that of some Upper Jurassic species of Astarte (s. s.), such as Astarte scytalis HoudHaus, 1913, from the Spiti shales of Himalayas and the Kimmeridgian of British Somaliland (Cox, 1935), but those species are much larger and have more anteriorly situated umbones and less persistent concentric ribs.

In the broad umbo and general outline, the present species is somewhat similar to Astarte ovula SMIтH from the Upper Jurassic, which is a member of Neocrassina. The cardinal tooth $5 \mathrm{~b}$ is absent in the present species, and in this respect it may be close to Neocrassina. However, the anterior lateral teeth are too stout, the concentric ribs are too irregular and the dimensions are too small to refer the present species to that subgenus.

Occurrence.-Aritan to upper Miyakoan (upper Neocomian to Albian). Grey sandy shale of the Ishido formation at loc. Hy. 4001, 4002, 4003, Ichinosebashi, south of Kagahara, Nakazato village, Tano County, Gumma Prefecture, and at loc. Hy. 4011, Ishido, Ohinata village, Minamisaku County, Nagano Prefecture. Grey fine sandstone of the Haidateyama formation at loc. U. 3095, Yamaguchi-no-tani, Mie town, Ono County, Oita Prefecture. Grey sandy shale of the Yatsushiro formation at loc. Km. 3037, west of Mt. Jogusan, Miyaji, Yatsushiro City, Kumamoto Prefecture. Grey sandy shale of the same formation at loc. At. 328, south of Bisho, Toyo village, Yatsushiro County, the same prefecture (AKATSU coll.). Dark grey sandy shale of the Hanoura formation at loc. Hy. 5004, north of Hiroyasu and at loc. Hy. 5012, 5015, east of Nakagoya, Katsuura town, Katsuura County, Tokushima Prefecture (Matsumoto, NAKaI and HAYAMI coll.).

Astarte (Astarte) sp. cf. A. (A.) subsenecta YABE and NAGAO Plate 11, Figures 9-10

Several specimens from the Oshima formation closely resemble Astarte (Astarte) subsenecta YABE and NAGA0, 1926, in the outline, convexity and ornamentation (GK. H 6584, both valves, $15.0+\mathrm{mm}$. long, $15.5 \mathrm{~mm}$. high, $8.5 \mathrm{~mm}$. thick; GK. H 6585, both valves, $18.0 \mathrm{~mm}$. long, $19.0 \mathrm{~mm}$. high, $10.5 \mathrm{~mm}$. thick). They are more or less fragmentary, and the test is partly eroded away. In view of the similar posterior truncation these specimens may be actually conspecific with $A$. (A.) subsenecta from the Ishido, Yatsushiro and some other formations in Southwest Japan, but the concentric ribs are sharper and the lunule is slightly larger and better defined than in that species. It is possible that the present specimens belong to a geographical subspecies of $A$. (A.) subsenecta, although a new name is not proposed here.

Occurrence.--Aritan (upper Neocomian). Black shale of the Oshima forma- 
tion at loc. Hy.0012, south of Yokonuma, Oshima island, Kesennuma City, Miyagi Prefecture (OBATA and HaYAmi coll.).

\section{Astarte (Astarte) costata YABE and NAGAO \\ Plate 8, Figures 1-2}

1926. Astarte subsenecta var. costata YABE and NAGAO, in YABE, NAGAO and ShIMIzU, Sci. Rep. Tohoku Imp. Univ., Ser. 2, Vol. 9, No. 3, p. 48, pl. 14, fig. 10.

Material.-The holotype by monotypy is a left valve (IGPS reg. no. 22483) illustrated by YABE, NAGAO and SHIMIZU (1926, pl. 14, fig. 10). It was collected from the "Kawarazawa formation" at Ôze, south of Kagahara, Nakazato village, Tano County, Gumma Prefecture. In addition to the lectotype two more specimens are concerned with the description below-GK. H 6408, from the Sanchu area (ICHIKAWA and HAYAMI coll.), and GK. H 6409, from the Choshi area (HAYAMI coll.).

Description.-Shell small, equivalve, not strongly inflated, polygonally ovate, longer than high; antero-dorsal margin moderate in length, slightly concave in front of umbo; postero-dorsal margin much longer than the antero-dorsal, a little convex; posterior margin subvertically truncated, clearly discriminated, forming obtuse angles with the postero-dorsal and ventral margins; umbo prosogyrous, rather narrow, slightly rising above the dorsal margin, situated at about two-fifths of shell-length from the anterior extremity; a weak rounded carina extends from the umbo to the postero-ventral periphery, delimiting clearly a broad posterior area; surface ornamented with about 15 concentric ribs, which become more sparse towards ventral margin but fairly persistent through the growth; growth-lines numerous on ribs and intervals; lunule narrowly elongate, compressed, delimited by a sharp ridge; internal characters unknown.

Measurements in mm.

$$
\begin{aligned}
& \text { Specimen } \\
& \text { Left valve (GK.H6408) } \\
& \text { Both valves (GK.H6409) }
\end{aligned}
$$

$\begin{array}{cccc}\text { Length } & \text { Height } & \text { Thickness } & \text { L/H } \\ 15.0 & 13.0 & \text { ca. } 2.0 & 1.15 \\ 14.5 & 13.0 & 3.0 & 1.12\end{array}$

Observations and comparisons.-A left valve and a bivalved specimen revealing external characters are identical with Astarte subsenecta var. costata YABE and NAGA0, 1926, from the "Kawarazawa formation" of the Sanchu area in the outline and surface ornamentation. The relationship between this "variety" and typical $A$. subsenecta is a matter of question, because an example from the Sanchu area is accompanied by numerous specimens of $A$. subsenecta in the same fossiliferous bed. Several specimens of $A$. subsenecta at the same locality have fairly persistent concentric ribs and appear at a glance to be intermediate. However, the typical specimens of $A$. subsenecta are characterized by smaller number of concentric ribs which are confined to the umbonal and middle part of the shell. Moreover, the holotype and the additional specimens here described 
show weaker convexity and narrower umbones than the lectotype and other examples of $A$. subsenecta. Therefore, I am now inclined to consider that this "variety" actually constitute a distinct species.

Occurrence.-Aritan and lower Miyakoan (upper Neocomian and Aptian). Fine sandstone of the Choshi formation at loc. Hy. 2001, Ashikajima, Choshi City, Chiba Prefecture. Grey sandy shale of the Ishido formation at loc. Hy. 4003, Ichinose-bashi, south of Kagahara, Nakazato village, Tano County, Gumma Prefecture. The type locality as recorded by YABE, NAGAO and SHIMIzU is at ôze in the "Kawarazawa formation" of the same area, and it is now located in the distributed area of the Ishido formation.

\section{Astarte (Astarte) semicostata NAGAo}

Plate 8, Figures 3-10

1934. Astarte semicostata NAGAo, Jour. Fac. Sci. Hokkaido Imp. Univ., Ser. 4, Vol. 2, No. 3, p. 221, pl. 31, figs. 3-5, pl. 32, fig. 6 (non pl. 25, fig. 2).

Material.-A left valve (GH. reg. no. 6792) illustrated by NAGAo (1934, pl. 31, fig. 3) is designated here as the lectotype. It was collected from the Hiraiga formation at the south of Hiraiga, Tanohata village, Shimohei County, Iwate Prefecture. Three of the syntypes (NAGA0, 1934, pl. 31, figs. 4, 5; pl. 32, fig. 6) are also the examples of this species, but one of the syntypes (pl. 25, fig. 2) belongs to another species, Astarte (Freiastarte) subomalioides NAGAo, 1934. Ten more specimens (GK. H 6410-GK. H 6415, GK. H 6653-GK. H 6656) from the type locality (HANAI and HAYAMI coll.) are concerned with the following description in addition to the lectotype and the three syntypes.

Description.-Shell very small, scarcely exceeding $8 \mathrm{~mm}$. in length, inequilateral, subquadrate in outline, not carinated, slightly longer than high, moderately inflated; test fairly thick; antero-dorsal margin feebly concave, forming a nearly right angle with the postero-dorsal margin; postero-dorsal margin slightly convex and passes gradually into the posterior; posterior margin smoothly rounded without any angulation; umbo prominent, slightly prosogyrous, placed at about one-third of shell-length from the anterior end; lunule moderate in depth, compressed, circumscribed by a ridge; escutcheon narrow, elongate, delimited by a sharp ridge; ligament external; umbonal region marked with several subequidistant concentric riblets, while in the central and ventral parts they are completely effaced; growth-lines very weak; hinge composed of two divergent cardinal teeth and a pair of weak lateral teeth in each valve, as formulated: $\frac{\mathrm{AI} 3 \mathrm{a} 3 \mathrm{~b} \text { (PIII) }}{\text { (AII) } 24 \mathrm{~b} \text { PII }}$ : $3 \mathrm{a}$ small; 2 and $3 \mathrm{~b}$ stout; $4 \mathrm{~b}$ thin; AII and PIII not clearly demarcated from the valve margin; adductor scars strongly impressed; pallial line entire; ventral margin finely crenulated internally; umbonal cavity comparatively shallow. 
Measurements in $\mathrm{mm}$.

\begin{tabular}{lcccc}
\multicolumn{1}{c}{ Specimen } & Length & Height & Thickness & L/H \\
Both valves (GK.H6410) & 6.5 & 6.5 & 3.5 & 1.00 \\
Both valves (GK.H6411) & 7.0 & 6.5 & 4.0 & 1.08 \\
Right valve (GK.H6412) & 6.5 & 6.0 & ca.1.5 & 1.08 \\
Right valve (GK.H6413) & 6.5 & 6.5 & ca.2.0 & 1.00 \\
Left valve (GK.H6414) & 7.5 & 7.0 & ca.2.0 & 1.07 \\
Left in. mould (GK.H6415) & 6.0 & 6.0 & ca.1.5 & 1.00 \\
Right valve (GK.H6653) & 6.5 & 6.5 & ca. 2.0 & 1.00 \\
Right valve (GK.H6654) & 6.0 & 6.0 & ca.1.5 & 1.00 \\
Left valve (GK.H6655) & 7.0 & 6.5 & ca.2.0 & 1.08 \\
Right valve (GK.H6656) & 6.5 & 6.0 & ca.1.5 & 1.08
\end{tabular}

Observations and comparisons.-Many specimens newly collected from the various localities of the Miyako group are identical with the lectotype of Astarte semicostata NAGAO, 1934. The shell convexity varies to a certain extent among them, but they have commonly similar concentric sculpture on the umbonal surface. The concentric ribs are generally weak, but in a few aberrant specimens such as the left valve (GK. H 6414) the sculpture is fairly persistent and distributed on the whole surface. The internal structure is known only in an internal mould of a left valve ( $\mathrm{GK} . \mathrm{H}$ 6415).

The present species is clearly distinguishable from the immature specimens of Eriphyla miyakoensis (NAGAO, 1927), which occur often in the same beds, by the shallower umbonal cavity, more quadrate outline and better developed cardinal tooth $4 \mathrm{~b}$. The hinge structure is quite different from that of coexistent Astarte (Freiastarte) subomalioides NAGAO, 1934, and Astarte (Nicaniella) minor NAGAO, 1934, in the presence of $3 \mathrm{a}$, and agrees better with that of Astarte (Astarte) subsenecta YABE and NAGA0, 1926. In all the specimens of A. (A.) subsenecta YABE and NAGA0, from the Sanchu, Yatsushiro and other areas, however, the dimensions are much larger, the posterior margin more distinctly truncated and the umbo located more centrally than in the present species.

As noted by NAGAO (1934), the present species must be a close ally to Astarte cantabridgiensis WooDs, 1906, from the Lower Greensand of England in view of the similar umbonal concentric riblets and subquadrate outline, and it might be possible that this is actually a geographic subspecies of $A$. cantabridgiensis. However, the former differs from the latter in the slightly narrower lunule, weaker shell convexity, smaller dimensions and less persistent concentric sculpture.

Occurrence.-Lower Miyakoan (Aptian). Calcareous sandstone of the Hiraiga formation at loc. Hn. 0017, 0018, southern coast of Hiraiga and at loc. Hn. 0914, 0916, 0920, northern coast of Haipe, Tanohata village, Shimohei County, Iwate Prefecture. NAGAO reported this species also from Hideshima of Sakiyama, Miyako City, the same prefecture. So far as I am aware, the occurrence of this species is restricted to the lower part of the Miyako group: 


\section{Astarte (Astarte?) sp. indet. \\ Plate 8, Figure 11}

This species is represented by a bivalved specimen (GK. $\mathrm{H} 6587,15.0 \mathrm{~mm}$. long, $11.5 \mathrm{~mm}$. high, $9.5 \mathrm{~mm}$. thick), the test of which is mostly eroded away in the right valve but well preserved in the left valve. Shell small, subovate, much longer than high; antero-dorsal margin concave, forming a deep lunule; umbo prosogyrous, placed anteriorly; escutcheon clearly delimited by a ridge; postero-dorsal area not clearly defined; surface marked with about 10 prominent, regular and almost persistent concentric ribs and numerous faint growth-lines; hinge and musculature unknown.

The present specimen is distinguishable from the coexistent specimens of Astarte (Astarte) sp. cf. A. (A.) subsenecta YABE and NAGAO by the more elongated shell, more anteriorly placed umbo, stronger shell convexity and not clearly truncated posterior margin. In typical specimens of $A$. subsenecta from various localities of Japan an obscure carina extends from the umbo to the postero-ventral periphery, defining a posterior area. Such a tendency is, however, not recognized in the present specimen. Astarte (Astarte) costata YABE and NAGAO, 1926, from the Sanchu and Choshi areas show similarly persistent concentric ribs, but the present specimen differs from that species in the stronger shell convexity, more transversely elongated outline and worse defined posterior margin. The present specimen probably belongs to a new species, but a specific name is not proposed here, because the material is incomplete.

Occurrence.-Aritan (upper Neocomian). Black shale of the Oshima formation at loc. Hy. 0012, south of Yokonuma, Oshima island, Kesennuma City, Miyagi Prefecture (OBAta and HaYami coll.).

\section{Subgenus Freiastarte CHaVAN, 1952}

\section{Astarte (Freiastarte) subomalioides NAGAO \\ Plate 8, Figures 12-18}

1934. Astarte subomalioides NAGAo, Jour. Fac. Sci. Hokkaido Imp. Univ., Ser. 4, Vol. 2, No. 3, p. 219, pl. 27, figs. 3, 4.

1934. Astarte semicostata NAGA0, Ibid., Ser. 4, Vol. 2, No. 3, p. 221 (pars), pl. 25, fig. 2, only (non pl. 31, figs. 3-5, pl. 32, fig. 6) .

1962. Astarte (Nicaniella) subomalioides, HaYAmI, Kaseki ("Fossils"), No. 4, p. 75 , listed.

Material.-A left valve (IGPS reg. no. 66446) illustrated by NAGAO (1934, pl. 27, fig. 3) is designated here as the lectotype. It was collected from the Hiraiga formation at the north of Hiraiga, Tanohata village, Shimohei County, Iwate Prefecture. The other syntype of NAGAo (1934, pl. 27, fig. 4) and, moreover, a specimen described by NAGAO (1934, pl. 25, fig. 2) as Astarte semicostata are also examples of this species. Seven more specimens (GK. H 6417GK. H 6421, GK. H 6657, GK. H 6658) from the type area (HANAI and HAYAMI coll.) are also concerned with the description below. 
Description.-Shell very small, scarcely exceeding $10 \mathrm{~mm}$. in length, inequilateral, subquadrate, slightly longer than high, weakly inflated; test thick; antero-dorsal margin a little concave in front of umbo to form a narrow lunule; postero-dorsal margin much longer than the antero-dorsal, nearly straight, forming an angle of about 110 degrees with the posterior margin; carina absent, but the posterior and ventral margins obscurely delimited from each other by a strong curvature; umbo a little prosogyrous, scarcely rising above the dorsal margin, placed at about two-fifths of shell-length from the anterior extremity; escutcheon narrow, clearly delimited by a very sharp ridge; lunule also sharply discriminated; surface decorated with strong concentric ribs, which are seven to nine in number, broad, rounded at the tops with steep dorsal slopes and gentle ventral slopes, becoming gradually more sparse towards the ventral margin; a steep marginal belt formed along the ventral periphery; hinge Nicaniella-like, composed of two divergent cardinal teeth and a pair of lateral

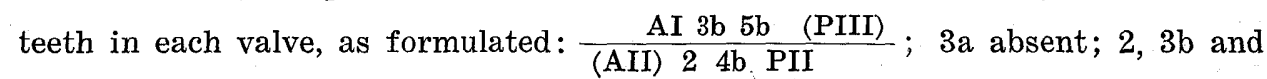
$4 \mathrm{~b}$ subtriangular, radiating from the beak; $5 \mathrm{~b}$ well developed along the nymph margin; AII and PIII very weak; adductor impressions comparatively. weak; pallial line entire; ventral margin very finely crenulated internally; umbonal cavity shallow; concentric ribs obscurely impressed on the internal surface.

\section{Measurements in $\mathrm{mm}$.}

$\quad$ Specimen
Left valve (GK.H6417)
Right valve (GK.H6418)
Left valve (GK.H6419)
Left valve (GK.H6420)
Right valve (GK.H6421)
Left valve (GK.H6657)
Right valve (GK.H6658)

$\begin{array}{cccc}\text { Length } & \text { Height } & \text { Thickness } & \text { L/H } \\ 9.0 & 8.0 & 2.5 & 1.13 \\ 8.0 & 7.0 & \text { ca. } 2.0 & 1.14 \\ 7.0 & 6.5 & \text { ca. } 2.0 & 1.08 \\ 8.5 & 7.5 & \text { ca. } 2.5 & 1.13 \\ 7.5 & 6.5 & \text { ca. } 2.0 & 1.15 \\ 7.0 & 6.5 & \text { ca. } 2.0 & 1.08 \\ 7.5 & 6.5 & ? & 1.15\end{array}$

Observations and comparisons.-More than seven specimens in the present collection are undoubtedly referable to Astarte subomalioides NAGA0, 1934. The outline is somewhat variable but the highly raised concentric sculpture, Nicaniella-like dentition and sharply delimited lunule and escutcheon characterize the present species. The hinge structure is observable in two specimens (GK. H 6657, GK. H 6658).

NAGAO compared the present species with Astarte omalioides WooDs, 1906, from the Gault of England, which was referred by CASEY (1961) to Freiastarte, but the former is evidently distinct from the latter in view of the more quadrate outline, broader concentric ribs, smooth interspaces and better defined posterior margin. Astarte subcostata D'ORBIGNY, 1850, which is also referable to Freiastarte, differs from the present species in the narrower concentric ribs and broader interspaces, although some specimens of that species from the Lower Greensand (Woods, 1906, pl. 15, figs. 1,2) are very similar to the present species in the external features. Astarte (Freiastarte) praetypica CASEY, 1961, which 
was proposed for Astarte sp. of Woops (1906, p. 111, pl. 15, figs. 3, 4) from the Lower Greensand, may be also a closely related species, but the umbonal angle is slightly smaller than in the present species.

In the diagnosis of the dentition, i.e. the absence of cardinal tooth $3 a$, it is quite different from all the species of Astarte (s. s.), and reminds one of Nicaniella CHAYAN, 1945, and Freiastarte CHAVAN, 1952, which are now considered as the subgenera of Astarte. Although I have ever referred the present species to Nicaniella (HAYAMI, 1962, p. 75), it should be included in Freiastarte in view of the nearly straight postero-dorsal margin, comparatively weak shellconvexity, sharply delimited lunule and escutcheon, subquadrate outline and strong concentric sculpture.

Occurrence.-Lower and upper Miyakoan (Aptian to Albian). Calcareous sandstone of the Hiraiga formation at loc. Hn. 0017, 0018, southern coast of Hiraiga, and at loc. Hn. 0916, north of Haipe, Tanohata village, Shimohei County, Iwate Prefecture. Calcareous sandstone of the 2nd cycle sediments of the Miyako group at loc. Hn. 4101, Matsushima and at loc. Hn. 4051, Oshima, both off the coast of Moshi, Iwaizumi town, the same county. A boulder of the Aketo formation at the northeast of Raga, Tanohata village. NAGAO reported this species also from the "Orbitolina sandstone" at Raga and from the Aketo formation at Aketo, the same village.

Astarte (Freiastarte) sp. cf. A. (F.) subomalioides NAGAO

Plate 8, Figure 24

Compare.-

1934. Astarte subomalioides NAGA0, Jour. Fac. Sci. Hokkaido Imp. Univ., Ser. 4, Vol. 2, No. 3, p. 219, pl. 27, figs. 3-4.

There are several poorly preserved internal and external moulds of a small astartid, which have widely spaced and highly raised concentric ribs. The shell convexity is weak, and this species may belong to Freiastarte. Ventral crenulations are imperceptible, but it may be due to unfavourable preservation. It is provisionally compared with Astarte (Freiastarte) subomalioides NAGA0, 1934, from the Miyako group by the resemblance of outline, concentric sculpture and dimensions, although there are many allied species in foreign Cretaceous faunas. The illustrated specimen is a right internal mould (GK. H 6423, $10.0 \mathrm{~mm}$. long, $8.5 \mathrm{~mm}$. high, ca. $1.5 \mathrm{~mm}$. thick).

Occurrence.-Upper Miyakoan (Albian). Grey sandy shale of the Yatsushiro formation at loc. Km. 3037, west of Mt. Jogusan, Miyaji, Yatsushiro City, Kumamoto Prefecture (KANMERA coll.).

Subgenus Nicaniella Chavan, 1945

Type-species.-Astarte communis ZITTEL and GoUBERT, Kimmeridgian, western Europe (original designation). 


\section{Astarte (Nicaniella) minor NAGAO \\ Plate 8, Figures 19-22}

1934. Astarte minor NAGAo, Jour. Fac. Sci. Hokkaido Imp. Univ., Ser. 4, Vol. 2, No. 3, p. 220, pl. 28, figs: 5-10.

Material.-Both valves (IGPS reg. no. 66425) illustrated by NAGAO (1934, pl. 28, fig. 5) is here designated as the lectotype. It was collected from the Hiraiga formation at the south of Hiraiga, Tanohata village, Shimohei County, Iwate Prefecture. Other syntypes of NAGAO (1934, pl. 28, figs.6-10) are also examples of this species. Six more specimens (GK. H 6425-GK. H 6428, GK. H 6662, GK. H 6663) from the type area (HANAI and HAYAMI coll.) are concerned with the description below in addition to the lectotype.

Description.--Shell very small for the genus, scarcely exceeding $6 \mathrm{~mm}$. in length, suboval in outline, subequilateral, nearly as high as long or slightly longer than high, not carinated, strongly inflated; antero-dorsal margin a little concave, while postero-dorsal margin is slightly convex; anterior, ventral and posterior margins well rounded without any angulation; umbo very prominent above the dorsal margin, contiguous, incurved, very slightly prosogyrous, placed nearly at the mid-point of length; lunule and escutcheon wide, delimited respectively by a ridge; surface ornamented with 11-14 strong, highly elevated, rounded and very persistent concentric ribs, which become gradually more sparse from the umbo to the ventral margin; one or two weaker riblets generally discernible on the ventral slope of each concentric rib; ventral margin coarsely crenulated internally; right valve possesses only one cardinal tooth $3 \mathrm{~b}$, which are bounded on both sides by sockets $2 b^{\prime}$ and $4 b^{\prime}$; $5 b$, if present, very weak; lateral teeth apparently undeveloped; umbonal cavity fairly deep.

Measurements in $\mathrm{mm}$.

Specimen
Both valves (GK.H6425)
Right valve (GK.H6426)
Right valve (GK.H6427)
Right valve (GK.H6428)
Both valves (GK.H6662)
Right valve (GK.H6663)

$\begin{array}{cccc}\text { Length } & \text { Height } & \text { Thickness } & \text { L/H } \\ 5.6 & 5.5 & 4.2 & 1.02 \\ 5.5 & 5.2 & \text { ca. } 1.9 & 1.06 \\ 5.7 & 5.3 & 2.0 & 1.08 \\ 6.0 & 5.6 & \text { ca. } 2.2 & 1.07 \\ 5.4 & 5.1 & 3.6 & 1.06 \\ 5.3 & 5.1 & \text { ca. } 2.0 & 1.04\end{array}$

Observations and comparisons.-Although the shell-convexity seems to be somewhat variable, this species is well characterized by the strong concentric ribs and subcentrally placed umbo. The hinge structure is observable only in one right valve (GK. $\mathrm{H}$ 6427), in which there is no distinct elevation corresponding to the cardinal tooth 5b. NAGAO described the dentition, "Cardinal teeth strong, numbering two in the right valve and one in the left, no well developed lateral teeth". However, NAGA0's right valve (1934, pl.28, fig. 9) has not a distinct posterior cardinal tooth 5b. Although I have not observed the hinge structure of a left valve, the dentition of this species may be able to be formulated: $\frac{3 b}{2 b \quad 4 b}$. 
The structure probably coincides with that of Astarte claxbiensis WooDs, 1906, from the "Belemnites lateralis beds" (Hauterivian) of England. The subequilateral outline and strong convexity are also very similar, but the concentric sculpture of the present species is more roughly spaced especially near the ventral margin and the dimensions are much smaller than in A. claxibiensis.

The small size, concentric sculpture and absence of cardinal tooth 3a suggest the subgenus Nicaniella for the present species. In fact, the present species resembles Astarte (Nicaniella) praemysis CHAVAN, 1945, and its related species from the Astartian (=Lower Kimmeridgian) of Calvados, although the umbonal region is narrower than in those species. The absence or weakness of a cardinal tooth $5 \mathrm{~b}$ and lateral teeth is, however, different from the dentition of typical Nicaniella.

The present species is clearly distinguishable from Astarte (Freiastarte) subomalioides NAGA0, 1934, from the same fossiliferous beds by the by far stronger convexity, less inequilateral outline, more strongly convex posterodorsal margin, more prominent umbo and coarser ventral crenulations.

Occurrence.-Lower and upper Miyakoan (Aptian to Albian). Calcareous sandstone of the Hiraiga formation at loc. Hn. 0017, 0018, southern coast of Hiraiga, and loc. Hn. 0914, 0916, north of Haipe, Tanohata village, Shimohei County, Iwate Prefecture. A boulder of calcareous sandstone of (?) the Aketo formation at the northeast of Raga, the same village. NAGAO reported this species also from the Aketo formation at Aketo, the same village.

\section{Subgenus Yabea nov.}

Type-species.-Astarte shinanoensis $\mathrm{YABE}$ and NAGAO, in YABE, NAGAO and SHIMIZU, 1926, upper Neocomian, Japan.

Diagnosis.-Medium-sized Astarte having inequilateral outline, strong shellconvexity, subterminal and extremely prosogyrous umbo, deeply excavated preumbonal margin and fine ventral crenulations; surface smooth or marked with weak concentric costae; dentition of Astarte (s. s.) type, as formulated:

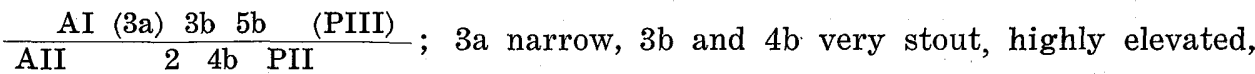
prosocline; 5b narrow, often not clearly separated from the nymph; pallial line simple; umbonal cavity profound.

Remarks.-This new subgenus includes Astarte bodei Wollemann, 1900, from the upper Neocomian of Germany, and Astarte akatsui sp. nov., from the Albian of west Japan, in addition to the type-species. In the dentition formula, especially the presence of the cardinal teeth $3 \mathrm{a}$ and $5 \mathrm{~b}$, Yabea may be closer to Astarte (s. s.) than to Nicaniella Chavan, 1945, and Freiastarte Chavan, 1952. However, all the cardinal teeth are more prosocline and more highly elevated than in those four subgenera. As to the exterior, the present subgenus is clearly distinguishable from Nicaniella, Freiastarte and Neocrassina by the absence of striking concentric sculpture and in the more prosogyrous and more anteriorly situated umbo. In many species of Astarte (s. s.), the umbonal 
region is marked with several concentric costae, even if the surface of the main part is nearly smooth. Such a tendency is, however, not recognized in the present type-species.

In most species of the Astartinae, a small pedal scar is clearly impressed behind the anterior adductor scar, but it is not strongly impressed in the present subgenus.

Some Upper Jurassic species of Astarte, such as Astarte kambarensis KIMURA, 1956, from the Torinosu group of southwest Japan, show similarly excavated pre-umbonal margin, prominent umbo and very prosocline cardinal teeth. Although the present subgenus may have been derived from such Upper Jurassic species, they differ from Yabea in the less prosogyrous umbo. Moreover, most of Jurassic species have more conspicuous concentric costae.

This subgenus is named after Prof. Emeritus Hisakatsu YABE of the Tohoku University, who has greatly contributed to the palaeontology of the Cretaceous pelecypods of Japan.

\section{Astarte (Yabea) shinanoensis YABE and NAGAO}

Plate 8, Figures 25, 26; Plate 14, Figures 7, 8

1926. Astarte shinanoensis YABE and NAGAO, in YABE, NAGAo and SHIMIZU, Sci. Rep. Tohoku Imp. Univ., Ser 2, Vol. 9, No. 3, p. 47, pl. 13, figs. 29,30 .

Material.-A right internal mould (IGPS reg. no. 22544) illustrated by YABE, NAGAO and SHImizu (1926, pl. 13, fig. 30) is designated as the lectotype. It was collected from the Ishido formation at Ishido, Ohinata village, Minamisaku County, Nagano Prefecture. The other syntype (pl. 13, fig. 29) is probably also an example of this species. Two more specimens (GK. H 6430, GK. H 6652) from the Sanchu area (ICHIKAWA and HAYAMI coll.) are also concerned with the description below.

Description.-Shell medium-sized, highly inequilateral, comparatively tall, slightly higher than long or nearly as high as long, strongly inflated; test fairly thick; antero-dorsal margin profoundly excavated in front of umbo, while postero-dorsal margin is gently convex, much longer than the antero-dorsal one; posterior margin poorly defined from the postero-dorsal and ventral margins; umbo strongly prosogyrous, highly protruded above the dorsal margin, incurved, placed very anteriorly; lunule deep, delimited by a weak ridge; escutcheon clearly delimited, comparatively narrow; ligament external, elongated; surface smooth except for fine concentric lines of growth; ventral margin finely crenulated internally; hinge plate triangular, unusually broad; dentition of Astarte

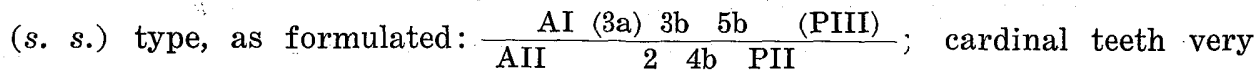
stout and highly elevated except for the weakly demarcated $5 \mathrm{~b} ; 3 \mathrm{a}$ comparatively narrow and not demarcated from the valve margin; 2 slightly prosocline, conical; $3 \mathrm{~b}$ and $4 \mathrm{~b}$ elongated; AI and AII comparatively weak; PII weak, elongated along the postero-dorsal margin; PIII absent or very weak; adductor 
scars subovate, strongly impressed, subequal in size; pedal scar not impressed; pallial line entire; umbonal cavity profound.

Measurements in $\mathrm{mm}$.

\begin{tabular}{lcccc}
\multicolumn{1}{c}{ Specimen } & Length & Height & Thickness & L/H \\
Right in. mould (GK.H6430) & $23.0+$ & 26.5 & 7.5 & $0.87+$ \\
Left in. mould (GK.H6652) & 24.0 & 24.5 & 7.0 & 0.98
\end{tabular}

Observations and comparisons.-The syntypes of this species are rather poorly preserved and more or less deformed secondarily, but the specific characters, i.e. the excavated pre-umbonal margin, very prosogyrous umbo and highly elevated cardinal teeth, are well recognized in the lectotype here designated. No other specimen from the type locality is at my disposal, but two well preserved specimens newly collected from the type formation at the eastern part of the Sanchu area are certainly conspecific with the lectotype. They reveal the characteristic hinge structure of two valves, although their test is completely eroded away. One of them (GK. H 6652) is composed of internal and external moulds, showing also the external characters of this species. They are somewhat larger than the syntypes, but agree well with the lectotype in every essential character. While YABE and NAGAO (1926) described the outline of $A$. shinanoensis to be "almost equilateral", the umbo is very prosogyrous and anteriorly situated in the syntypes and the two present specimens.

The present species is readily distinguishable from Astarte (Astarte) subsenecta YABE and NAGA0, 1926, which is commonly found together in the same fossiliferous bed, by the stronger shell-convexity, the more prominent and prosogyrous umbo, the profound umbonal cavity and the different disposition of the cardinal teeth.

Astarte bodei WollemanN, 1900, from the upper Neocomian of Germany, resembles the present species in many essential characters, and may be inclusive in the same subgenus. However, the umbonal cavity is somewhat shallower and the surface concentrics are more conspicuous than in the present species.

Occurrence.-Aritan (upper Neocomian). Grey sandy shale of the Ishido formation at loc. Hy. 4003, Ichinose-bashi, south of Kagahara, Nakazato village, Tano County, Gumma Prefecture. The present species was originally reported from the Ishido formation at Ishido, Ohinata village, Minamisaku County, Nagano Prefecture.

Astarte (Yabea) sp. aff. A. (Y.) shinanoensis YABE and NAGAO

Plate 9, Figure 1; Plate 14, Figure 9

This species is represented here by an internal mould of left valve (GK. H 6774, $23.0 \mathrm{~mm}$. long, $18.5 \mathrm{~mm}$. high, $6.0 \mathrm{~mm}$. thick). Although the surface ornament is not observable, the hinge structure and the mode of marginal crenulation are very similar to those of the preceding species, Astarte (Yabea) shinanoensis $\mathrm{YABE}$ and NAGAO, 1926, from the Ishido formation of the Sanchu area. It is, however, different from the typical specimens of $A$. 
shinanoensis in the more transversely elongated outline. Because the present specimen occurred from a fairly brittle sandstone, the difference of the outline is hardly assignable to the secondary deformation. It is likewise somewhat similar to Astarte (Yabea) akatsui sp. nov. from the Yatsushiro formation of the Yatsushiro area, but the pre-umbonal margin is more deeply excavated and the ratio of length/height is still larger than in the undeformed specimens of that species.

Occurrence.-Aritan (upper Neocomian). Grey fine sandstone of the Hanoura formation at loc. Hy. 5002, Hiroyasu, Katsuura town, Katsuura County, Tokushima Prefecture (HAYAMi coll.).

Astarte (Yabea) akatsui sp. nov.

Plate 9, Figures 2-5; Plate 14, Figures 10, 11

Material.-The holotype is a left internal mould (GK. H 6171) collected from the Yatsushiro formation at loc. At. 328, south of Bisho, Toyo village, Yatsushiro County, Kumamoto Prefecture (AKATsu coll.). Paratypes (GK. $\mathrm{H}$ 6172-GK. $\mathrm{H}$ 6174) from the type locality (AKATSU coll.).

Description.- Shell small- or medium-sized, subovate in outline, very inequilateral, expanded postero-ventrally, strongly inflated, not carinated, more or less longer than high; antero-dorsal margin deeply excavated in front of umbo; anterior margin strongly curved; postero-dorsal margin nearly straight, unusually long, passing gradually into the posterior margin; ventral margin broadly arcuate, not clearly defined from the posterior margin; umbo prominent, very prosogyrous, overhanging lunule; escutcheon narrow, delimited by an weak ridge; surface smooth except for fine concentric lines of growth; ventral margin finely crenulated internally; crenulations about 75 in number, becoming somewhat weaker towards the posterior side; valve margin bluntly edged with a narrow flattened belt; hinge plate triangular, moderate in breadth; dentition formulated

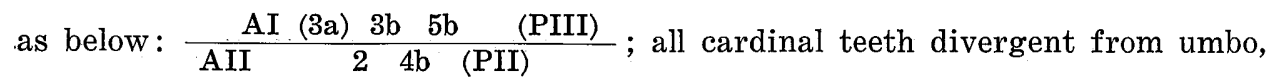
prosocline, slightly curved downwards, very stout except for thin $3 a$ and not distinctly demarcated 5b; AI and AII short, weak; posterior lateral teeth generally undeveloped; adductor scars subovate, strongly impressed; pedal scar not impressed; pallial line entire; umbonal cavity profound.

Measurements in $\mathrm{mm}$.

Specimen

Holotype (GK.H6171) left in. mould

Paratype (GK.H6172) left in. mould

Paratype (GK.H6173) right in. mould

Paratype (GK.H6174) right in. mould

$\begin{array}{cccc}\text { Length } & \text { Height } & \text { Thickness } & \text { L/H } \\ 20.0 & 19.5 & 6.0 & 1.03 \\ 21.0 & 19.0 & 5.5 & 1.11 \\ 23.0 & 18.0 & 6.0 & 1.28 \\ 19.5 & 19.0 & 6.0 & 1.03\end{array}$

Observations and comparisons.-Four internal moulds show the characteristic outline and hinge structure. Although their external moulds are frag- 
mentary, it is recognized that the surface is nearly smooth except for weak growth-lines. The ratio of length/height and the position of umbo are somewhat variable, partly due to the slight secondary deformation. In all the available specimens, however, the length slightly exceeds the height, and the umbo is very anteriorly placed. The present species is well characterized also by the strong shell-convexity, prosogyrous umbo, fine marginal crenulations, profound lunule and strong curvature of the anterior margin.

The present species is certainly a close ally to Astarte (Yabea) shinanoensis YABE and NAGA0, 1926, from the Ishido formation of the Sanchu area, and is inclusive in the same subgenus. The ratio of length/height is, however, somewhat larger, and the hinge plate is distinctly narrower than in the typical specimens of $A$. shinanoensis.

Some specimens of Astarte sakamotoensis TAMURA, 1959, from the Upper Jurassic of the same area resemble the present ones in the outline, but the concentric sculpture is conspicuous and the shell convexity is comparatively weak in that species. This is also simlar to a specimen described by TAMURA (1960, pl.33, fig. 17) from the Upper Jurassic of the Soma area as Astarte kambarensis. KImURA, 1956. But the typical specimens of $A$. kambarensis from the Torinosu group of Shikoku and Kyushu (TAmURA, 1959, pl. 5, fig. 13) show a less strongly prosogyrous and more centrally placed umbo and more conspicuous concentric ribs than the present species.

This species is named after Mr. Takeshi AKATsU, the collector of the present material.

Occurrence.-Upper Miyakoan (Albian). Grey sandy shale of the Yatsushiro formation at loc. At. 328, south of Bisho, Toyo village, Yatsushiro County, Kumamoto Prefecture.

\section{Subfamily Eriphylinae \\ Genus Eriphyla GABB, 1864}

Type-species.-Eriphyla umbonata GABB, 1864, Turonian, California (monotypy).

Remarks.-Different opinions have been expressed as to the systematic position of Eriphyla. SToLiczKa (1871) and some others placed Eriphyla in the Dosiniinae (of the Veneridae), while Fischer (1887), HolzapFeL (1889) and some others regarded it as a member of the Astartidae. Woods (1906) treated it as a subgenus of Astarte, although he included several species of Neocrassina also in Eriphyla. STEWART (1930), who examined a part of GABB's. collection of Eriphyla umbonata, suggested with a query that it belongs to the Cyprinidae (=Arcticidae). Subsequently, a detailed study on the hinge structure of this group was undertaken by CHAVAN (1941). He examined the dentition of several European species, which appeared to be congeneric with Eriphyla umbonata, and came to a conclusion that Eriphyla belongs to the Astartidae. His subfamily Eriphylinae was recently accepted by IcHIKAWA and MAEDA 
(1963).

The hinge structure of the type-species of Eriphyla was schematically figured by GABB (1864, pl. 24, figs. 162, 162a), but the specimen has been said to be missing (STEWART, 1930). As pointed out by POPENOE (1937), Eriphyla lapidis (PACKARD, 1922) and Eriphyla ovoides (PACKARD, 1922) from the Senonian of California may be, if not identical with, closely related to $E$. umbonata. In Europe, Astarte striata SowERBY, 1826, from the Upper Greensand of England, has been considered by Woods (1906), STEWART (1930) and many others as an example of Eriphyla.

So far as judged from the above cited species, the hinge structure of Eriphyla seems to be characterized by the narrow cardinal tooth 4 b, which is commonly not clearly demarcated from the nymph. CHAVAN (1945) interpreted that the anterior lateral teeth of Eriphyla represent AIII and AIV instead of AI and AII, and the notation was recently adopted by ICHIKAWA and MAEDA (1963). In fact, the inner lateral tooth of the right valve is apparently continuous to 3a in many species of Eriphyla, and, if the former is actually related to the latter, the lateral tooth should be called AIII for the right valve and AIV for the left. However, as seen in the present specimens of Eriphyla miyakoensis (NAGA0, 1927), there is a narrow interruption between the cardinal and anterior lateral teeth in both valves. The relationship has not been ascertained also in other species of Eriphyla with an ontogenetical evidence. In most species of Astarte (s. s.) and Neocrassina, the anterior lateral teeth in similar position are properly called AI and AII, and I interpret here that the anterior laterals of Eriphyla are homologous with those of the Astartinae.

The presence of a shallow pallial sinus probably constitute a diagnostic character of Eriphyla. It is known in Eriphyla striata (SOWERBY, 1826) and also in some species from the Lower Cretaceous of Japan. Woops (1906) stated that a similar pallial sinus exists in some Cretaceous species of Astarte, which are now referable to Neocrassina, and it is likewise known in Tetoria KoBAYASHI and SUZUKI, 1937, and Yokoyamaina HAYAMI, 1958, which are certainly unrelated to the Veneracea. Therefore, the presence of a pallial sinus is not a character indicating that Eriphyla has something to do with the "Sinupalliaten".

\section{Subgenus Eriphyla s. str.}

Diagnosis.-Eriphyla characterized by the smooth and non-crenulated inner ventral margin even in the adult stage; surface concentrically striated.

Remarks.-Eriphyla can be divided at least into two subgenera, i.e. Eriphyla (s. s.) and Miyakoella nov., by the absence or presence of crenulations along the interior of the ventral margin. The former is mostly found in the Albian and Upper Cretaceous, and may have been derived from the latter, which appeared at first in the Upper Jurassic and probably became extinct by the end of Lower Cretaceous. Some authors including ChAvaN (1952) have considered that Dozyia Bosquet in Dewalque, 1868 (type-species: Lucina lenti- 
cularis GoLDFUSS, 1836) is also a distinct group or a subgenus in the genus Eriphyla. It seems to be characterized by the more lenticular outline and weaker shell-convexity than Eriphyla (s. s.).

Eriphyla (Eriphyla) pulchella sp. nov.

Plate 9, Figures 6-12; Plate 14, Figure 6

Material.-The holotype is a right valve (GK. H 6442) collected from the upper part of the "Orbitolina sandstone" of the Miyako group at loc. Hn. 6203, northeast of Raga, Tanohata village, Shimohei County, Iwate Prefecture (HANAI and HAYAMI coll.). Paratypes (GK. H 6443-GK. H 6447) from the type locality (HANAI and HAYAMI coll.).

Description.-Shell small- or medium-sized for the genus, scarcely exceeding $18 \mathrm{~mm}$. in length, suborbicular but invariably longer than high, strongly inflated; test moderate in thickness; antero-dorsal margin broadly concave, while postero-dorsal margin is nearly straight; posterior margin not clearly delimited, passing gradually into the postero-dorsal and ventral margins; umbo comparatively narrow, prominent above the dorsal margin, prosogyrous, placed at about three-sevenths of shell-length from the anterior end; lunule narrow, moderately deep, obscurely demarcated; escutcheon narrow, delimited by a sharp ridge; surface ornamented with densely spaced regular concentric lines; ventral margin apparently smooth without crenulations; hinge plate moderate in breadth; hinge unknown in detail but may be formulated: $\frac{\text { AI } 3 \mathrm{a} 3 \mathrm{~b}}{2(4 \mathrm{~b})}$; 2 nearly vertical, $3 \mathrm{~b}$ stout, triangular; $3 \mathrm{a}$ and $4 \mathrm{~b}$ narrow; lateral teeth undeveloped except for AI and AII; umbonal cavity deep; musculature not observed in the present material.

Measurements in $\mathrm{mm}$.

$\begin{array}{cccccc}\text { Specimen } & \text { Length } & \text { Height } & \text { Thickness } & \text { L/H } \\ \text { Holotype (GK.H6442) } & \text { right valve } & 17.5 & 16.0 & 5.0 & 1.09 \\ \text { Paratype (GK.H6443) } & \text { right valve } & 17.0 & 15.5 & 4.5 & 1.10 \\ \text { Paratype (GK.H6444) } & \text { right valve } & 16.5 & 16.0 & 4.5 & 1.03 \\ \text { Paratype (GK.H6445) } & \text { both valves } & 17.0 & 16.0 & 8.5 & 1.06 \\ \text { Paratype (GK.H6446) } & \text { right in. mould } & 15.5 & 14.0 & 4.0 & 1.11 \\ \text { Paratype (GK.H6447) } & \text { right valve } & 17.0 & 16.0 & 4.5 & 1.06\end{array}$

Observations and comparisons.-Ten specimen are available for the present study. The test is well preserved in five of them including the holotype and paratypes (GK. H 6443-GK. H 6445, GK. H 6447). The ratio of length/height is slightly variable, but the present species is characterized by the slightly transversely elongated outline and the almost regular concentric lines on the surface. In an artificial internal mould (GK. H 6446), a hinge structure of Eriphyla-type can be observed, although the detailed character is missing owing to the coarse grained matrix.

If the smaller dimensions are ignored, the present species is fairly similar to Eriphyla miyakoensis (NAGA0, 1927) which is very common in the lower 
part of the Miyako group. However, the umbo is placed a little more centrally, the average ratio of length/height distinctly larger, the lunule much shallower and the concentric lines are more regular and more conspicuous than in $E$. miyakoensis. Internally the present species is clearly distinguishable from $E$. miyakoensis by the absence of marginal crenulations and the narrow hinge plate.

Eriphyla playfordi Cox, 1961, from the (?) Lower Cretaceous of Western Australia has similarly narrow hinge plate and similar disposition of cardinal teeth, but the dimensions are larger and the surface is marked with more irregular concentric lamellae than in the present species. In the surface ornamentation the present species resembles Eriphyla elegans ICHIKAWA and MAEDA, 1963, from the Maastrichtian part of the Izumi group of Japan, but the shell convexity is weaker and the ratio of length/height is distinctly larger in the former than in the latter.

Occurrence.-Upper Miyakoan (Albian). Dark grey sandy shale of the upper part of the "Orbitolina sandstone" at loc. Hn. 6202, 6203, northeast of Raga, and similar sandy shale of the Aketo formation at loc. Hn. 6201, northeast of Raga, Tanohata village, Shimohei County, Iwate Prefecture.

Eriphyla (Eriphyla) minima sp. nov.

Plate 9, Figures 13-16; Plate 14, Figures 12-13

Material.-The holotype is a left internal mould (GK. H 6181) collected from the Yatsushiro formation at loc. At. 328, south of Bisho, Toyo village, Yatsushiro County, Kumamoto Prefecture (AKatsu coll.). Two paratypes (GK. H 6182, GK. H 6183) from the Yatsushiro area (AKATsU coll.) and another paratype (GK. H 6449) from the Sanchu area (HAYAmi coll.).

Description.-Shell very small for the genus, suborbicular, inequilateral, not strongly inflated, slightly longer than high or nearly as long as high; umbo placed at about two-fifths of length from the anterior end, rather improminent, prosogyrous, scarcely rising above dorsal margin; antero-dorsal margin concave in front of umbo, sloping down to the anterior margin; postero-dorsal margin long, slightly convex; posterior margin slightly truncated, forming obtuse angles with the postero-dorsal and ventral margins; anterior part of shell somewhat flattened; Iunule and escutcheon narrow but well defined; ventral margin flattened internally, not crenulated; umbonal cavity rather shallow; hinge of Eriphyla-type, as formulated: $\frac{\text { (AI) } 3 \mathrm{a}}{\text { (AII) } 3 \mathrm{~b}} \frac{\text { PIII }}{2(4 \mathrm{~b}) \text { PII }}$; cardinal teeth divergent from the beak, flattened at the tops; 2 and $3 \mathrm{~b}$ stout, triangular; $3 \mathrm{a}$ thin; $4 \mathrm{~b}$ not clearly delimited from the nymph; anterior lateral teeth undeveloped, while posterior ones are elongated along the postero-dorsal margin; both adductor scars subovate, clearly impressed; pallial line with a very shallow sinus; umbonal region ornamented with several weak rounded concentric ribs, but the remaining part quite smooth except for growth-lines. 
Measurements in $\mathrm{mm}$.

$\begin{array}{ccccc}\text { Specimen } & \text { Length } & \text { Height } & \text { Thickness } & \text { L/H } \\ \text { Holotype (GK.H6181) left in. mould } & 15.0 & 15.0 & 3.0 & 1.00 \\ \text { Paratype (GK.H6182) left in. mould } & 10.5 & 10.0 & 2.0 & 1.05 \\ \text { Paratype (GK.H6183) left ex. mould } & 15.0 & 14.5 & 3.0 & 1.03 \\ \text { Paratype (GK.H6449) left in. mould } & 18.0 & 17.5 & 4.0 & 1.03\end{array}$

Observations and comparisons.-Three left internal and a left external moulds are at hand, but the right valve is not represented in the present material. One of the paratypes (GK. H 6449) from the Sanchu area is larger than other specimens from the Yatsushiro area, but the hinge structure is just the same. The present species resembles Eriphyla miyakoensis (NAGA0, 1927) from the Miyako group in the suborbicular outline and the mode of a shallow pallial sinus. However, the dimensions are much smaller and the ventral margin lacks crenulations in the present species. Eriphyla pulchella sp. nov. from the upper part of the Miyako group shows similarly smooth inner ventral margin, but the outline is less orbicular and the concentric ornaments are more conspicuous than in the present species. The hinge plate seems somewhat broader than in $E$. pulchella and the umbo is less prominent than in the two Miyako species.

Eriphyla umbonata GABB ? in STEWART (1930) seems to be comparable with the present species with regard to the dimensions and outline, but the concentric ribs are much weaker and the shell convexity appears to be somewhat weaker than in that species. Eriphyla lenticularis (GoLDFUss, 1836) and its allied species from the Upper Cretaceous of Europe, west Africa and India (STOLICZKa, 1871; Holzapfel, 1889; FreNeIX, 1957, etc.), which have been considered by some authors to constitute a distinct subgenus Dozyia BOSQUET in DeWALqUe, 1868, have larger size, more lenticular outline and less flattened anterior area.

Occurrence.-Aritan and upper Miyakoan (upper Neocomian to Albian). Grey sandy shale of the Yatsushiro formation at loc. At. 328, south of Bisho, Toyo village, Yatsushiro County, Kumamoto Prefecture. Grey sandy shale of the Ishido formation at loc. Hy. 4003, Ichinose-bashi, south of Kagahara, Nakazato village, Tano County, Gumma Prefecture.

\section{Subgenus Miyakoella nov.}

Type-species.-Astarte miyakoensis NAGA0, in YABE, 1927, Aptian-Albian, north Japan.

Diagnosis.-Medium-sized Eriphyla characterized by finely crenulated inner ventral margin; surface smooth or concentrically striated; other characters similar to those of Eriphyla (s. s.)

Remarks.-The ancestry of Eriphyla is not as yet very clear, but I think that it was derived from a certain suborbicular species of Astarte in the Late Jurassic times. Astarte subdepressa Blake and Hudleston, 1877 (=Astarte pasiopae D'ORBIGNY, 1927 (1850)), from the Corallian of England (ARKkLL, 
1934) and the upper part of the Jurassic Soma group of Japan (TAMURA, 1960) shows similar outline and dentition to the Cretaceous species of Eriphyla. In the type specimen of A. pasiopae D'OrBIGNY, as figured in Types du Prodrome (Annal. Paléont., Vol. 16, pl. 45, figs. 27, 28, 1927) and also by ArKell (1934, pl. 33, fig. 2, 2a), numerous fine crenulations are clearly marked along the interior of the ventral margin. Similar fine crenules also observable in the mature specimens of Eriphyla miyakoensis (NAGA0, 1927) and a few other species from the Lower Cretaceous. Such crenulations are, however, absent in the Upper Cretaceous species of Eriphyla including many species closely related to the type-species.

The presence or absence of marginal crenulations in the adult stage can be generally regarded as a criterion of subgeneric or even generic importance. For an example, Tridonta Schumacher, 1817, is subgenerically distinguishable from Astarte (s. s.) by the smooth ventral margin (HABE, 1951, etc.). Although the internal characters are not completely known in some Cretaceous species of Eriphyla, I propose here a new subgenus, Miyakoella, for the species of Eriphyla having crenulated internal margin... I designate Eriphyla miyakoensis as the type-species of this subgenus, because every external and internal character is best exhibited in this species. Eriphyla (s. s.) was probably derived from Miyakoella, so far judged from the stratigraphic occurrence.

In addition to the type-species, the present subgenus may include Astarte weissermeli DiETRICH, 1933, from the Neocomian of east Africa, and Eriphyla argentina BURCKHART, 1903, from the Neocomian of Argentina. Those two species show similarly crenulated internal margins to the type-species. Astarte subdepressa BlAKE and HUdLESToN, 1877, from the Upper Jurassic of England, France and Japan, is regarded here as an early representative of Miyakoella. Astarte upwarensis Woods, 1906 (=Astarte n. sp. in KEEPING, 1883, p. 122, pl. 6, fig. 9), probably belongs also to this subgenus, because it is quite similar to the type-species in the external features, although its internal characters has not been described.

The present subgenus is clearly distinguishable from Dozyia BosQuET in Dewalque, 1868, which shows more lenticular outline and smooth internal margin. The occurrence of Dozyia is probably restricted to the Upper Cretaceous.

\section{Eriphyla (Miyakoella) miyakoensis (NAGAo) \\ Plate 10, Figures 1-8; Plate 11, Figures 1-8}

1927. Astarte miyakoensis NAGAo, in YABE, Sci. Rep. Tohoku Imp. Univ., Ser. 2, Vol. 11, No. 1, pl. 4, fig. 5 (no description).

1934. Astarte miyakoensis, NAGA0, Jour. Fac. Sci. Hokkaido Imp. Univ., Ser. 4, Vol. 2, No. 3, p. 218 , pl. 30 , fig. 8 , pl. 32, figs. 1, 3-5.

1962. Eriphyla miyakoensis, HAYAMI, Kaseki ("Fossils"), No. 4, pp. 69, 75, text-fig. 6.

Material.-The holotype by monotypy is a left valve (IGPS reg. no. 7105) illustrated by YABE (1927, pl. 4, figs. 5a, b) and also by NAGAO (1934, pl. 32, 
figs. 3, 3a). It was collected from the Hiraiga formation at Hiraiga, Tanohata village, Shimohei County, Iwate Prefecture. Other specimens illustrated by NAGAO (1934, pl. 30, fig. 8, pl. 32, figs. 1, 4, 5) are also good examples of this species. 17. more specimens (GK. H 6432-GK. H 6441, GK. H 6664-GK. H 6670) from the type area (HANAI and HAYAMI coll.) are also concerned with the description below.

Description.-Shell medium-sized for the genus, suborbicular in outline, nearly as long as high, moderately inflated, never carinated; test thick and solid; antero-dorsal margin comparatively long, weakly concave in front of umbo, passing gradually into the ventral margin without any angulation; posterodorsal margin moderate in length, broadly convex, gradually bent down towards the posterior margin; posterior margin not clearly discriminated; ventral margin broadly arcuate; umbo prosogyrous, overhanging lunule, prominent above dorsal margin, placed at about two-fifths of shell-length from the anterior end; escutcheon delimited by a weak ridge, narrow, nearly vertical; lunule moderate in width, profound, circumscribed by a blunt ridge; surface quite smooth except for numerous faint concentric lines of growth; ligament external; hinge plate triangular, broad; dentition constant, of typical Eriphyla, as formulated: $\frac{\text { AI } 3 \mathrm{a} 3 \mathrm{~b}}{\mathrm{AII} \quad 2(\mathrm{PIII})}$ (PII) ; cardinal teeth stout, highly elevated, acutely triangular, divergent from the beak, similar in strength except for somewhat rounded and tubercle-like $3 \mathrm{a}$ and ill-defined and narrow $4 \mathrm{~b} ; 3 \mathrm{a}$ apparently continuous from the short lateral tooth $\mathrm{AI}^{*}$; AII fairly stout; PII sometimes not clearly defined from the inner margin of the hinge plate; PIII elongated and distinct; PIVlike ridge present in the left valve but there is no corresponding socket in the right valve; adductor scars subequal in size, clearly impressed; pedal scar obscurely impressed; pallial line shallowly sinuated below the posterior adductor scar; ventral margin finely serrated internally; umbonal cavity fairly deep.

\section{Measurements in $\mathrm{mm}$.}

Specimen
Both valves (GK.H6432)
Right valve (GK.H6433)
Right valve (GK.H6434)
Left valve (GK.H6435)
Right valve (GK.H6436)
Left valve (GK.H6437)
Left valve (GK.H6438)
Both in. mould (GK.H6439)
Left valve (GK.H6440)
Left valve (GK.H6441)
Right valve (GK.H6441)
Right valve (GK.H6664)
Both valves (GK.H6665)
Both valves (GK.H6666)

* See also p. 97 for the notation.

$\begin{array}{cccc}\text { Length } & \text { Height } & \text { Thickness } & \text { L/H } \\ 33.0 & 33.0 & 17.5 & 1.00 \\ 29.0 & 29.5 & 8.5 & 0.98 \\ 31.0 & 32.0 & 9.5 & 0.97 \\ 33.0 & 31.5 & 9.0 & 1.05 \\ 32.0 & 33.0 & 9.5 & 0.97 \\ 29.0 & 30.5 & 9.0 & 0.95 \\ 27.5 & 30.0 & 8.5 & 0.92 \\ 26.5 & 26.5 & 15.0 & 1.00 \\ 30.5 & 29.5 & 8.0 & 1.03 \\ 25.5 & 26.0 & ? & 0.98 \\ 25.5 & 25.5 & ? & 1.00 \\ 30.0 & 31.0 & 9.5 & 0.97 \\ 25.5 & 27.0 & 15.0 & 0.94 \\ 20.0 & 19.5 & 11.0 & 1.03\end{array}$


Left valve (GK.H6667)

Left valve (GK.H6668)

Right valve (GK.H6669)

Both valves (GK.H6670)
24.0

19.0

31.5

35.5
24.0

19.5

31.5

37.0
$?$

$? \quad 0.97$

$9.0 \quad 1.00$

$19.5 \quad 0.96$

Observations and comparisons.-A large number of well preserved specimens exhibiting the internal and external characters can be certainly referred to Astarte miyakoensis NAGAO in YABE (1927). Although the description of this species was first made by NAGAO (1934), YABE's (1927) denomination (explanation of plate 4, figs. 5a, b) should be regarded as valid. YABE's illustrated specimen is, therefore, regarded as the holotype (by monotypy). In the Miyako group, closed specimens in juxtaposition are not rare but usually a little deformed secondarily. Univalved specimens seem to retain the original outline. The ratio of length/height is somewhat variable among the undeformed specimens, ranging from 0.92 to 1.05 . The dentition can be precisely examined in several specimens (GK. H 6436-GK. H 6438, GK. H 6667, GK. H 6668), and the presence of a shallow pallial sinus is recognized in an internal mould of closed valves (GK. H 6439). The marginal crenulation is observable in many specimens, although they are not preserved in water-worn ones.

The hinge structure of the present species was shown in NAGA0's figures (1934, pl. 30, fig. 8; pl.32, figs. 3a, 4a), but the internal characters were not fully described by him. The obscurely defined cardinal tooth $4 \mathrm{~b}$ and the general disposition of the cardinal and lateral teeth are identical with those of typical Eriphyla.

The present species was compared by NAGAO (1934) with Astarte upwarensis Woods, 1906, from the Lower Greensand of England, which should be included in Eriphyla, as indicated by CASEY (1961, p. 607). NAGAO noted that $E$. miyakoensis differs from $E$. upwarensis in the slightly narrower umbo, less convex postero-dorsal margin and narrower escutcheon. However, the former two criteria are obscure, so far as the variation of $E$. miyakoensis. was examined. More distinct criteria to distinguish the present species from $E$. upwarensis: seem to exist in the larger dimensions and the different mode of convexity. In $E$. upwarensis the convexity becomes remarkably stronger near the ventral: margin, whereas such a tendency is very slight in the present species. The adult specimens of $E$. miyakoensis exceed $30 \mathrm{~mm}$. in length and height, but. those of $E$. upwarensis are about $20 \mathrm{~mm}$. according to Woods. The internal characters of $E$. upwarensis are imperfectly known, but the cardinal tooth $4 \mathrm{~b}$ may be better delimited from the nymph than in the present species.

In many characters the present species resembles Eriphyla stuhlmanni MÜlleR in BoRnhart (1900) and Astarte weissermeli DIETRICH, 1933, from the Tendaguru formation of east Africa. A shallow pallial sinus and marginal crenulations are also known in the latter species. But the cardinal tooth $3 \mathrm{a}$. is distinctly larger and the $3 \mathrm{~b}$ is less elongated than in $E$. stuhlmanni, and the surface concentric lines are less conspicuous than in $E$. weissermeli. Eriphyla playfordi Cox, 1961, from the (?) Lower Cretaceous of Western 
Australia seems to differ from the present species in the less orbicular outline and narrower hinge plate. Eriphyla argentina BURCKHART, 1903 from the Neocomian of Argentina (WEAVER, 1931) resembles the present species in the dentition and the mode of marginal crenulations, but the outline is more elliptical and the surface ornamented with more prominent concentric lines than in the present species.

A number of Upper Cretaceous species of Eriphyla, such as Eriphyla meridiana (Woods, 1917) from the Senonian of New Zealand, E. elegans ICHIKAWA and MAEDA, 1963, and E. japonica ICHIKAWA and MAEDA, 1963, from the Campanian-Maestrichtian of Japan, E. lapidis (PACKARD, 1922) from the lower Senonian of California, and E. striata (Sowerby, 1826) (Woods, 1906) from the Upper Greensand of England, show similar outline and dentition to the present species, but their ventral margin is not crenulated and their surface is marked with more conspicuous concentric striae.

Occurrence.-Lower and upper Miyakoan (Aptian to Albian). Calcareous sandstone of the Hiraiga formation at loc. Hn. 0010, 0017, 0018, southern coast of Hiraiga, at loc. Hn. 0911, 0914, north of Haipe, Tanohata village, Shimohei County, Iwate Prefecture. Conglomeratic sandstone of the Tanohata formation at loc. Hn. 0802, 0803, Koikorobe, the same village. Calcareous sandstone of the 2nd cycle sediments of the Miyako group at loc. Hn. 4051 (gregarious bank), Oshima, off the coast of Moshi, Iwaizumi town, the same county. Calcareous sandy shale of the Aketo formation at loc. Hn. 0671, 6201, northeast of Raga, Tanohata village.

Eriphyla (Miyakoella) sp. cf. E. (M.) miyakoensis (NAGAO)

1957. Astarte cf. miyakoensis NAGAO, Amano, Kumamoto Jour. Sci., Ser. B, Sec. 1, Vol. 2, No. 2, p. 96, pl. 2, figs. 19-24.

Remarks.-This species is not represented in the present collection. As compared by AMANo (1957), a similar species to Eriphyla (Miyakoella) miyakoensis (NAGAO, 1927) occurs from the Hagino formation. The hinge structure is very similar to that of $E$. miyakoensis, although the cardinal tooth $4 \mathrm{~b}$ may be slightly more distinct in the present species. Marginal crenulation is not observable in the present species, but it may be due to the unfavourable preservation.

Occurrence.-Lower Miyakoan (Aptian). Weathered fine sandstone of the Hagino formation at Hagino, Mirafu village, Kami County, Kochi Prefecture (according to AMANO).

\section{Subfamily Opisinae}

Genus Opis Defrance, 1825

Type-species.-Trigonia cardissoides LAMARCK, 1819, Cenomanian, western Europe (by monotypy). The holotype by monotypy of this species was illustrated, the original figures and diagnosis by LAMARCK (1819) and Defrance 
(1825) were reprinted by BIGoT (1904, p. 21, 21a).

Subgenus Opis s. str.

Opis (Opis) nakanoi sp. nov.

Plate 11, Figures 11-12

Material.-The holotype is a right valve (GK. H 6451) collected from the 1st cycle sediments of the Miyako group at the coast of Hideshima of Sakiyama, Miyako City, Iwate Prefecture (NAKano coll.). Paratype (GK. H 6452) from the same locality (NAKANo coll.).

Description.-Shell comparatively large for the genus, subtrigonal in outline, higher than long, moderately inflated; test thick; antero-dorsal margin deeply excavated, forming a nearly right angle with the antero-ventral margin; postero-dorsal margin slightly convex near the umbo but weakly concave near the postero-dorsal angle; posterior margin nearly vertical, slightly concave, distinctly demarcated from the postero-dorsal and ventral margins, meeting the latter with an approximately right angle; ventral margin passes gradually into the anterior; umbo slightly prosogyrous, pointed, protruded very highly above the dorsal margin, placed more or less anteriorly from the mid-point of length; a prominent carina extending from the umbo to the postero-ventral angle, defining sharply a concave posterior area; escutcheon delimited from the posterior area by a rounded ridge; lunule wide, profound, circumscribed also by a rounded ridge; hinge plate triangular, wide, provided with a cardinal tooth in the right valve and two cardinal teeth in the left, as formulated: $\frac{3 \mathrm{~b}}{24 \mathrm{~b}}$; $3 \mathrm{~b}$ triangular, clear-cut, very stout, flattened at the top, provided with several oblique striae on the anterior and posterior walls; 2 nearly vertical, thin; $4 \mathrm{~b}$ elongated, ridge-like; lateral teeth undeveloped; ligament external; musculature unknown; umbonal cavity profound; ventral margin crenulated internally; surface smooth except for numerous growth-lines which form irregular erect lamellae near the ventral margin.

Measurements in $\mathrm{mm}$.

$\begin{array}{rlcccl}\text { Specimen } & \text { Length } & \text { Height } & \text { Thickness } & \text { L/H } \\ \text { Holotype (GK.H6451) } & \text { right valve } & 37.5 & 43.5 & 15.5 & 0.86 \\ \text { Paratype (GK.H6452) } & \text { right valve } & 37.0+ & 53.0 & 18.5 & 0.70+\end{array}$

Observations and comparisons.-The holotype is fairly well preserved, showing the hinge and external characters, although it may have suffered slight secondary deformation. The subvertically elongate outline, highly salient umbo, presence of oblique striations on the lateral walls of the cardinal tooth 3a and deep lunule indicate that this species belongs to Opis (s. s.) instead of Trigonopis Munier-Chalmas, 1887, and Coelopis Munier-Chalmas, 1887.

An excellent study on the subfamily Opisinae was recently undertaken by UEDA (1963), who published a diagnostic table of genera and subgenera and a systematically rearranged specific list. 
The present species is probably allied to Opis (Opis) haldonensis Woods, 1907, from the Upper Greensand of England in view of the similar outline and large dimensions. But the umbo is more strongly recurved, the cardinal teeth less elongated, the lunule more profoundly excavated and the ventral crenulation probably more conspicuous than in that species. In some characters it may be closer to Opis neocomiensis D'OrbIGNY, 1844, from the Lower Greensand of England and the Aptian of France. Woons' figure (pl. 17, fig. 12) of $O$. neocomiensis especially. resembles these specimens in the hinge structure and the shape of the dorsal valve margin. However, the dimensions of these specimens are much larger and the shell is more quadrate with a better demarcated posterior margin than in O. neocomiensis. Opis (Trigonopis) haginoensis Amano, 1957, from the Miyakoan Hagino formation of Shikoku, which I regard as a member of Opis (s. s.), differs from the present species in the smaller size, more triangular outline and apparently smooth inner ventral margin. The posterior margin of $O$. haginoensis is also clearly demarcated but nearly straight, while it is distinctly concave in the present species. Opis (Opis) amakusensis UEDA, 1963, from the Urakawan of west Kyushu, and $O$. (O.) hokkaidoensis UEDA, 1963, from the Hetonaian of eastern Hokkaido resemble the present species in the disposition of the cardinal teeth and oblique striations on them, but the shell is less quadrate and taller than in the present species. The posterior area of $O$. (O.) nakanoi is more distinctly concave and the inner marginal crenulation seems to be coarser than that of $O$. amakusensis.

The present species is named after Dr. Mitsuo NAKANo of the Hiroshima University, the collector of the present material.

Occurrence.-Lower Miyakoan (Aptian). Dark grey muddy shale of the 1st cycle sediments of the Miyako group at the coast of Hideshima of Sakiyama, Miyako City, Iwate Prefecture.

Opis (Opis) haginoensis AMANo

1957. Opis (Trigonopis) haginoensis AmaNo, Kumamoto Jour. Sci., Ser. B, Sec. 1, Vol. 2, p. 97, pl. 2, figs. 25, 26.

Remarks.-This species is not represented in the present collection. AMaNo (1957) assigned this species to the subgenus Trigonopis MUNIER-Chalmas, 1887. However, as he compared it with Opis neocomiensis D'ORBIGNY, 1844, and other species of Opis (s.s.), the outline and hinge revealed in his specimens GT. KML-0045, KML-0046) indicate that it is better referred to Opis (s. s.). Occurrence-Lower Miyakoan (Aptian). Weathered fine sandstone of the Hagino formation at Hagino, Mirafu village, Kami County, Kochi Prefecture (according to AmaNo, 1957).

Opis (Opis) sp. indet.

Plate 9, Figure 17; Plate 13, Figure 12

This species is at present represented by a specimen (GK. H. 6775) which 
is composed of left internal and external moulds ( $5.5 \mathrm{~mm}$. long, $6.5 \mathrm{~mm}$, high, $2.5 \mathrm{~mm}$. thick). The hinge is not exposed, but the sharply carinated triangular outline suggests Opis (s. s.) for the present specimen. In the external features it is somewhat similar to Opis (Opis) neocomiensis D'ORBIGNY, 1844, but the dimensions are by far smaller than those of $O$. neocomiensis. In view of the depressed posterior area and the absence of ventral crenulations, it is not impossible that the present specimen represents the juvenile stage of Opis (Opis) nakanoi sp. nov., which is found from the same horizon of the Miyako group.

Occurrence.-Lower Miyakoan (Aptian). Calcareous sandstone of the Hiraiga formation at loc. Hn. 0017, southern coast of Hiraiga, Tanohata village, Shimohei County, Iwate Prefecture (HAYAmi coll.).

\author{
Family Crassatellidae \\ Subfamily Crassatellinae \\ Genus Pachythaerus CONRAD, 1869
}

Type-species.-Crassatella vindinnensis D'ORBIGNY, 1843, Upper Cretaceous, western Europe (original designation).

\title{
Pachythaerus kagaharensis (YokoYama)
}

Plate 13, Figures 7-11; Plate 14, Figures 14-15

1890. Crassatella kagaharensis YokoYama, Palaeontographica, Bd. 36, p. 200, pl. 25, figs. 14, 15.

1963. Pachythaerus kagaharensis, Hayami in Matsumoto, A survey of the fossils from Japan illustrated in classical monographs, p. 32, pl. 25, figs. 14, 15. (nomenclatorial revision and reproduction of original figures)

Material.-Crassatella kagaharensis was originally described on the basis of two incomplete specimens which came from "Kagahara". Since I have not as yet observed the specimens, the lectotype is not designated here. Four specimens (GK. H 6453-GK. H 6456) from the type area (ICHIKAWA and HAYAMI coll.) are concerned with the description below.

Description.-Shell of medium size, inequilateral, trigonally oblong, much longer than high, moderately inflated; test moderate in thickness; antero-dorsal margin slightly concave in front of the umbo, passing gradually into the anterior margin; postero-dorsal margin much longer, nearly straight, forming an obtuse angle with the posterior margin; umbo prosogyrous, pointed but scarcely rising above the dorsal margin, placed at about one-fourth of shell-length from the anterior end; Iunule absent; escutcheon elongated along the postero-dorsal margin, delimited by a ridge; a rounded carina extending from the umbo to the postero-dorsal angle, defining a slightly concave postero-dorsal slope; surface ornamented with a number of rounded concentric riblets; ligament almost internal, deeply sunk in a subtriangular resilifer pit which is placed at the 
postero-dorsal part of the hinge plate and obscurely limited from the exterior by the extension of postero-dorsal marginal elevation; dentition not much different from that of Astarte, as formulated: $\frac{\text { AI (3a) } 3 b \quad \text { PIII }}{\text { AII } \quad 34 \text { PII }}$; very thin and small; 2 nearly vertical, connected with AII; $3 \mathrm{~b}$ triangular, stout; $4 \mathrm{~b}$ somewhat elongated and placed just below the resilifer; transverse striae unknown on the lateral walls of the cardinal teeth; both lateral teeth elongated along the margins but comparatively narrow; anterior adductor scar subovate, while posterior one is suborbicular; pallial line entire; ventral margin crenulated internally; umbonal cavity rather deep.

Measurements in mm.

\section{Specimen}

Right in. mould (GK.H6453)

Right in. mould (GK.H6454)

Left in. mould (GK.H6455)

Both valves (GK.H6456)

$\begin{array}{cccl}\text { Length } & \text { Height } & \text { Thickness } & \text { L/H } \\ 31.5 & 25.0 & 5.5 & 1.26 \\ 29.0 & 23.0 & 5.0 & 1.26 \\ 22.5+ & 21.0 & 5.0 & 1.07+ \\ 26.5+ & 21.0+ & 9.5 & 1.26 \pm\end{array}$

Observations and comparisons.-In addition to the above measured specimens there are several fragmentary specimens in the present collection. YoKoYAMA's syntypes do not reveal the internal characters, but the present internal moulds (GK. H 6453-GK. H 6455) show a characteristic resilifer pit of crassatellid-type. Although I have not examined the syntypes, the present specimens which were collected also near Kagahara (probably from the type locality), are seemingly conspecific with YokoYamA's in view of the similar oblong outline and conspicuous concentric sculpture.

In all the Cenozoic and Recent species of Crassatellites a resilifer occupies the posterior half of the hinge plate and all the cardinal teeth are opisthocline or acline. In the present species, however, the posterior cardinal tooth is very prosocline in each valve and the resilifer, which is not completely internal, is situated above it. The umbo is distinctly prosogyrous. Therefore, the present species appears to be intermediate between the Astartidae and Crassatellidae, as AMANo (1956) suggested about an allied species, Pachythaerus nagaoi (MAтsumoto). Such an intermediate level of ligament suggesting the the derivation of the Crassatellidae from the Astartidae, is commonly seen in the Cretaceous, and Pachythaerus CONRAD, 1869, is generally applicable as a generic name.

The oblong outline and anteriorly placed umbo resemble those of Crassatella saxoneti PICTET and Roux, 1847, from the Aptian-Albian of western Europe, for which CASEY (1961) proposed genus Seendia. The European species is, however, characterized by the more flat-sided dorsal view resembling that of Prorokia BoEHM, 1883, of the Astartidae and more strongly impressed adductor and pedal scars than the present species. CASEY stated that the hinge plate of Seendia is narrow, while it is fairly broad in the present species.

Specifically the present species is fairly close to Crassatella (Pachythaerus) nagaoi Matsumoto, 1938, from the Gyliakian (Cenomanian+Turonian) Gosyo- 
noura group of west Kyushu. AMANo (1956, p. 74) noted that there is no resilifer in that species. He interpreted that the posterior cardinal socket " $2 b$ "* is separated into two parts, large upper part and small lower part. But the "upper part" is nothing but a resilifer, because the corresponding part in the right valve is also a similar depression. Such a resilifer is clearly observable in all the specimens of Pachythaerus nagaoi from the Gosyonoura and Shishijima islands including the syntypes, Amano's specimens and newly collected ones. Amano interpreted the hinge structure of $P$. nagao $i$ as follows: $\frac{3 \mathrm{a} 1(3 \mathrm{~b})}{2 \mathrm{a} 2 \mathrm{~b}}$. The formula is quite different from mine, but no essential difference is ascertained between the internal structures of $P$. kagaharensis and $P$. nagaoi. Nevertheless, the average size of the former is distinctly larger, the outline more quadrate with more distinctly truncated posterior margin, the umbonal cavity somewhat deeper and the surface marked with more conspicuous concentric lines than in the latter.

Crassatella arcacea ROEMER, 1841, from the Upper Cretaceous of western Europe (HolzAPFeL, 1889; VAN DER WEIJDEN, 1943), which was referred to Pachythaerus by STEWART (1930), resembles the present species in some characters, but the adult shells of $C$. arcacea appear much longer and heavier, and the posterior carina is more conspicuous than in P. kagaharensis.

Occurrence.-Aritan (upper Neocomian). Grey fine sandstone of the Ishido formation at loc. Hy. 4001, Ichinose-bashi, south of Kagahara, Nakazato village, Tano County, Gumma Prefecture.

\section{Subfamily Scambulinae \\ Genus Anthonya GABB, 1864}

Type-species.-Anthonya cultriformis GABB, 1864, Upper Cretaceous, California (monotypy).

Remarks..-Anthonya is a characteristic heterodont genus in the Cretaceous. It is widely distributed in North America, western Europe, South Africa, New Zealand and Japan, but the hinge structure of most species has not been sufficiently described. STEWART (1930) examined the original specimens of Anthonya cultriformis, but the hinge was said to be unexposed in them. Anthonya cantiana Woods, 1906, and Anthonya woodsi CASEY, 1961 (=Anthonya sp. of Woods (1906)) from the Lower Greensand and the Folkstone of England seem to have established on the basis of well preserved specimens, but their hinges were neither described nor illustrated. GILLET's (1924, p. 110, fig. 69) and Chavan's (1939, p. 32, fig. 7) figures of the hinge of Anthonya cornueliana (D'ORBIGNY, 1844) were reproduced from the classical original illustration of that species, and are, therefore, rather schematic. Several Upper Cretaceous species such as Anthonya elongata Woods, 1917, from New Zealand, A. apicalis NAGAo and $A$. japonica MATsumoto from Japan, the hinge structure of which

\footnotetext{
* It should be correctly called $4 b^{\prime}$.
} 
is well known, show crescentic outline and probably are subgenerically separable from typical Anthonya.

The hinge structure is, however, fortunately clearly exhibited in several specimens of Anthonya subcantiana NAGA0, 1934, at my disposal (pl.6, figs. 2-4). The disposition of the cardinal teeth is fairly similar to that of GABB's original figure (1864, pl. 30, fig. 236a), and is also somewhat similar to that of Scambula perplana CONRAD, 1869, from the Upper Cretaceous of North America (WELLER, 1907, pl. 61, figs. 13, 14; WADE, 1926, pl. 25, figs. 11, 12, 15, 16; Stephenson, 1941, pl.26, figs. 11, 12), which is the type-species of Scambula CoNRAD, 1869. CHAVAN (1939) regarded Astarte sinuata in GILLET (1921) as a member of Scambula, and proposed Scambula gilleti for it. The dentition of $S$. gilleti can be formulated: $\frac{\mathrm{AI} 3 \mathrm{~b} 5 \mathrm{~b} \text { PIII }}{\text { AII } 24 \mathrm{~b} \text { PII PIV }}$, and agrees well with that of $A$. subcantiana, although PII is not so well demarcated in the latter species. STEWART (1930) suggested that Scambula can be hardly separated from Anthonya, but the former is regarded here as distinct from the latter, because the umbo is more prosogyrous, the outline less elongated and the post-umbonal margin more deeply excavated. VoKES (1946) proposed Midiraon (type-species: $M$. divaticatum) for a highly compressed shell from the Aptian of Lebanon, which is probably related to Scambula. Furthermore, Remondia GABB, 1869 (type-species: R. furcata GABB, 1869) may be related to Anthonya and Scambula. Although the constituent species of these genera are relatively few, it is here considered that Anthonya, Scambula, Midiraon and Remondia constitute a distinct taxonomic group, Scambulinae*, which is commonly characterized by the compressed and posteriorly curved outline, sinuated post-umbonal margin and subinternal ligament. So far as I am aware, the occurrence of this subfamily is restricted to the Cretaceous, although in the Palaeogene of Japan there are some crassatellitids showing similarly posteriorly curved outline.

\section{Anthonya subcantiana NAGAO}

Plate 12, Figures 1-11; Plate 13, Figures 2-5

1934. Anthonya subcantiana NAGAo, Jour. Fac. Sci. Hokkaido Imp. Univ., Ser. 4, Vol. 2, No. 3, p. 222, pl. 25, fig. 11, pl. 30, figs. 6, 7.

Material.-A left valve (GK. reg. no. 6768) illustrated by NAGAo (1934, pl. 30, fig. 7) is designated here as the lectotype. It was collected from the Hiraiga formation at Haipe, Tanohata village, Shimohei County, Iwate Prefecture. Other syntypes are also good examples of this species. 15 more specimens (GK. H 6464-GK. H 6471, GK. H 6671, GK. H 6672, GK. H 6783-GK. H 6787) from the type area (HANAI and HAYAMI coll.) are also concerned with the description below.

* CASEY (1961, p. 580) introduce the name of Scambulidae, but I am not sure who first gave this group a name of family-group. 
Description.-Shell small- or medium-sized for the genus, equivalve, elongate-trigonal, highly inequilateral, gradually tapering towards the posterior end, much longer than high, nearly flat; test moderate in thickness; anterodorsal margin very long, nearly straight or broadly concave, forming an umbonal angle of about 90 degrees with the antero-dorsal; posterior margin subvertically truncated; umbo orthogyrous, pointed but not rising above the dorsal margin, placed very anteriorly but not terminal; a blunt carina extends from the umbo to the postero-ventral angle, defining a narrow and slightly concave posterodorsal area from the disk; escutcheon very narrow; lunule not impressed; surface ornamented with regularly spaced concentric ribs which are somewhat broader than their interspaces and strengthened on the anterior and posterodorsal areas; ribs and interspaces marked with faint growth-lines; hinge plate wide, subtriangular, although the nymph is very narrow; cardinal teeth clearcut, comparatively narrow, elongated, divergent from the beak, two in each valve; 2 slightly opisthocline, $3 \mathrm{~b}$ acline, $4 \mathrm{~b}$ and $5 \mathrm{~b}$ slightly prosocline; AI and AII short, weak; PII and PIII elongated along the postero-dorsal margin, weakened towards the umbo; PIV undeveloped and not clearly demarcated from the valve margin; dentition, therefore, formulated: $\frac{\text { AI } 3 \mathrm{~b} 5 \mathrm{~b} \text { PIII }}{\text { AII } 24 \mathrm{~b} \text { PII (PIV) }}$; ligament opisthodetic, short, subinternal, sunk in a shallow elongated depression behind the posterior cardinal tooth in each valve; anterior adductor scar subovate, strongly impressed; weak internal buttress developed behind the anterior adductor scar, provided with a small pedal scar; posterior adductor scar weakly impressed almost half way to the posterior extremity; ventral margin finely crenulated internally; umbonal cavity very shallow.

Measurements in $\mathrm{mm}$.

\begin{tabular}{lcccl}
\multicolumn{1}{c}{ Specimen } & Length & Height & Thickness & L/H \\
Right valve (GK.H6464) & $19.5+$ & 12.0 & ca. 1.5 & $1.62+$ \\
Left valve (GK.H6465) & 23.0 & 12.5 & ca. 1.5 & 1.80 \\
Left valve (GK.H6466) & 25.5 & 13.0 & ca. 1.5 & 1.95 \\
Right valve (GK.H6467) & 24.5 & 13.5 & ca. 2.0 & 1.81 \\
Right valve (GK.H6468) & 17.0 & 9.5 & ca. 1.0 & 1.79 \\
Left valve (GK.H6469) & 22.0 & 12.0 & ca. 1.5 & 1.83 \\
Left valve (GK.H6470) & 20.5 & 12.0 & ca. 1.5 & 1.71 \\
Left valve (GK.H6471) & 21.0 & 12.0 & ca. 2.0 & 1.75 \\
Right valve (GK.H6671) & 26.0 & 14.0 & ca. 2.0 & 1.86 \\
Left valve (GK.H6672) & 19.0 & 11.0 & ca. 1.5 & 1.73 \\
Left valve (GK.H6783) & $22.0+$ & 12.5 & ca. 2.0 & $1.76+$ \\
Right valve (GK.H6784) & 21.0 & 12.0 & ca. 1.5 & 1.75 \\
Right in. mould (GK.H6785) & 18.5 & 10.0 & ca. 1.0 & 1.85 \\
Left in. mould (GK.H6786) & 18.0 & 10.0 & ca. 1.0 & 1.80 \\
Left valve (GK.H6787) & 21.5 & 13.0 & ca. 2.0 & 1.65
\end{tabular}

Observations and comparisons.-A number of well preserved specimens in the present collection are referable to Anthonya subcantiana NAGA0, 1934, by the similar outline and ornamentation to the lectotype. This species is considerably variable in the ratio of length/height. The postero-dorsal margin is 
nearly straight in some specimens but distinctly concave in other ones. The hinge and musculature are best preserved in the specimen GK. H 6464 and also observable in two internal moulds (GK. H 6785, GK. H 6786).

The present species is literally similar to Anthonya cantiana WooDs, 1906, from the Gault of England, although the internal characters of that species is still unknown. NAGAO noted, " $A$. cantiana has a more elongated shell with a slightly smaller apical angle, a more concave postero-dorsal margin and a more irregularly rounded posterior end". So far as the lectotype and many specimens in the present collection are concerned, this difference may indeed be recognized, but the specific distinction can hardly be based on such characters in view of the wide range of intraspecific variation. The concentric ribs on the postero-dorsal area are nearly vertical and nearly straight in $A$. subcantiana, while they are less regular and distinctly concave in $A$. cantiana, as figured by Woods (1906). The antero-ventral margin of $A$. cantiana is apparently more strongly curved than that of the Japanese species. The average size of A. subcantiana seems to be slightly smaller than that of $A$. cantiana, which is as long as $30 \mathrm{~mm}$. in WooDs original specimens. Anthonya aff. cantiana of GILLET (1921), from the Upper Barremian of France, may be closer to the species, because the concentric ribs are similarly regular. It is concluded that the present species is probably distinct from $A$. cantiana, but further information on the variation and internal structure of that species is needed for an accurate comparison.

In the hinge structure the present species is fairly similar to Anthonya cultriformis GABB, 1864, as originally figured, but the former has a smaller and less elongated shell and more sharply truncated posterior margin. One of GABB's specimens illustrated by STEWART (1930, pl.4, fig. 5) differs from the present specimens in the subterminal umbo and shorter antero-dorsal margin.

The present species is different from Anthionya cornueliana (D'ORBIGNY, 1844) from the Neocomian of France in the more anteriorly situated umbo, steeper and shorter antero-dorsal margin and more densely spaced concentric ribs, although no photographic illustration of that species is as yet accessible. Anthonya subhercynica (MAAs, 1895) from the Albian of Germany has a larger apical angle and more quadrate outline. Anthonya lineata KITCHIN, 1908, from the Lower Cretaceous of South Africa shows shorter and less inequilateral outline than the present species, so far as judged from the original illustration.

Anthonya apioalis NAGA0, 1938, from the Gyliakian formations of Hokkaido and Southwest Japan, Anthonya japonica Matsumoto, 1938, from the Gyliakian of west Kyushu, and Anthonya elongata WooDs, 1917, from the Senonian of New Zealand are clearly different from the present species in having terminal and pointed umbo, more ensiform (or crescentic) outline and larger dimensions.

Occurrence.-Lower and Upper Miyakoan (Aptian to Albian). Calcareous. sandstone of the Hiraiga formation at loc. Hn. 0016, 0017, 0018, southern coast of Hiraiga, and at the north of Haipe (exact locality unknown), both in Tano- 
hata village, Shimohei County, Iwate Prefecture. Grey sandy shale of the Tanohata formation at loc. Hn. 0220, northern coast of Hiraiga. Grey sandy shale of the upper part of the "Orbitolina sandstone" at loc. Hn. 6203, northeast of Raga, the same village. Similar specimens were found also in the calcareous sandstone of the 1st cycle sediments of the Miyako group at Oshima, off the coast of Moshi, Iwaizumi town, the same county. NAGAO reported the present species also from the Aketo formation at Aketo, Tanohata village.

\section{Anthonya sp. aff. A. subcantiana NAGAO}

Plate 13, Figure 6

A poorly preserved internal mould of left valve of Anthonya from the Sanchu area is similar to Anthonya subcantiana NAGAo, 1934, from the Miyako group in the dimensions and internal structure, but may belong to another species in view of the more centrally placed umbo, larger umbonal angle and less conspicuously truncated posterior margin. In these respects it appears to be more intimate to Anthonya cornueliana (D'ORBIGNY, 1844) from the Neocomian of France, but their precise comparison is impossible at present, because the present material is poor and no reliable illustration of $A$. cornueliana is accessible at present. The illustrated specimen (GK. H 6475), left internal mould, $22.5 \mathrm{~mm}$. long, $9.5 \mathrm{~mm}$. high, ca. $1.5 \mathrm{~mm}$. thick.

Occurrence.-Aritan (upper Neocomian). Grey fine sandstone of the Ishido formation at loc. Hy. 4001, Ichinose-bashi, south of Kagahara, Nakazato village, Tano County, Gumma Prefecture (IchIKaWA and HaYami coll.).

\section{Suborder Oligodontina \\ Superfamily Lucinacea \\ Family Lucinidae}

Genus Lucinoma DALL, 1901

Type-species.-Lucina filosa STIMPSON, Recent (original designation).

Lucinoma (?) kotoi. (NAGAO)

Plate 15, Figures 4-6

1934. Lucina kotoi NagA0, Jour. Fac. Sci. Hokkaido Imp. Univ., Ser. 4, Vol. 2, No. 3 , p. 226, pl. 29 , figs. 5,6 .

Material.-The holotype is a left valve (GH. reg. no. 6773) illustrated by NAGAO (1934, pl. 29, fig. 6). It was collected from the Hiraiga formation at Hiraiga, Tanohata village, Shimohei County, Iwate Prefecture. The paratype (NAGAO, 1934, pl.29, fig. 5) is also an example of this species. Three more specimens (GK. H 6476, GK. H 6477, GK. H 6686) from the type area (HANAI and HAYAMI coll.) are also concerned with the description below.

Description.-Shell small for the genus, slightly inequilateral, orbicularly ovate, longer than high, weakly inflated, not carinated; test thin; antero-dorsal 
margin slightly concave in front of the umbo, whereas postero-dorsal margin is broadly arcuate and passes gradually into the posterior margin; umbo slightly prosogyrous, placed slightly anteriorly from the mid-point of length, scarcely rising above the dorsal margin; lunule probably small, circumscribed by a sharp ridge; escutcheon distinct; surface marked with numerous narrow concentric lamellae, which are somewhat irregular in interval and prominence but usually much narrower than their interspaces; hinge and musculature unknown.

Measurements in $m m$.

Specimen
Right valve (GK.H6476)
Right valve (GK.H6477)
Right valve (GK.H6686)

$\begin{array}{cccc}\text { Length } & \text { Height } & \text { Thickness } & \text { L/H } \\ 14.5 & 13.5 & 3.0 & 1.07 \\ 14.5 & 13.0 & 3.5 & 1.12 \\ 13.0 & 12.0 & 3.0 & 1.08\end{array}$

Observations and comparisons.-Three specimens in the present collection are certainly identical with Lucina kotoi NAGA0, 1934, from the Miyako group. Although the ratio of length/height of these specimens may be slightly smaller than that of the holotype, the ornamentation and other external characters are quite similar. Since the musculature and hinge structure of the present species is unknown, its taxonomic position cannot be determined on a firm basis. In view of the outline and ornamentation, the present species is similar to Lucinoma among many genera of the Lucinidae. According to CHavaN (1937-1938), who made a comprehensive study on the classification of fossil and living lucinids, Lucinoma appeared after Eocene and was probably derived from Mesomiltha which persisted from the Lower Jurassic to the Neogene. It may be possible that the present species proves to belong to the latter genus, when the internal characters come to knowledge. As compared by NAGA0, the present species is fairly similar to and probably congeneric with Lucina valdensis Pictet and CAMPICHE, 1865, from the Aptian of Switzerland.

Occurrence.-Lower and upper Miyakoan (Aptian to Albian). Calcareous sandstone of the Hiraiga formation at loc. Hn. 0017, 0018, southern coast of Hiraiga, Tanohata village, Shimohei County, Iwate Prefecture. Grey sandy shale of the upper part of the "Orbitolina sandstone" at loc. Hn. 6203, northeast of Raga, the same village. NAGAo reported this species also from the Aketo formation at Aketo.

Lucinoma (?) sp. indet.

Plate 15, Figure 3

1954. Lucina (Myrtea) cfr. ezoensis Nagao, Matsumoto, Cret. System, Japan. Islands, p. 76, listed.

This species is represented by a specimen composed of internal and external moulds of a closed individual. The hinge structure is unknown, but the concentric ornamentation is clearly impressed on the external moulds. It resembles Lucinoma (?) kotoi (NAGA0, 1934) from the Miyako group, but differs from 
that species in the more excavated pre-umbonal margin and more widely spaced concentric lines. The present species was once compared with Lucina (Myrtea) ezoensis NAGAO, 1938, from the Gyliakian of Hokkaido, but the dimensions are smaller and the outline is less equilateral than in that species.

The illustrated specimen (GK. H 6687) left external mould, $14.0 \mathrm{~mm}$. long, $12.0 \mathrm{~mm}$. high, $2.5 \mathrm{~mm}$. thick.

Occurrence.-Weathered brown muddy shale of the lower part of the Arita formation at loc. Ys. 8, a road-side cutting between Yuasa and Suhara, Yuasa town, Arita County, Wakayama Prefecture (Matsumoto coll.).

Family Fimbriidae

Genus Fimbria MEGERLE, 1811

(=Corbis CuvieR, 1817)

Type-species.-Fimbria magna MEGERLE, 1811 (=Venus fimbriata LINNAEUS, 1758), Recent, Indo-Pacific (monotypy).

Fimbria sp. indet.

Plate 15, Figure 7

This species is represented by a specimen, which consists of an incomplete internal mould and a fragmentary external mould. Shell small for the genus, moderately inflated (left internal mould, GK. H 6593, 27.5 + mm. long, 24.0+mm. high, $8.0 \mathrm{~mm}$. thick); test probably thick; antero-dorsal margin slightly concave; umbo not prominent, a little prosogyrous; hinge plate fairly wide, provided with a small posterior cardinal tooth $4 \mathrm{~b}$ and a stout, conical anterior cardinal tooth 2 in the left valve; anterior lateral teeth AII and AIV isolated and short; surface ornamented with numerous radial riblets and somewhat widely spaced concentric ribs; radials strong on the anterior and posterior parts, forming a network with the concentrics; ventral margin finely crenulated internally in accordance with the radials; umbonal cavity very shallow.

Although the right valve and the disposition of the posterior lateral teeth are unknown, the present specimen is certainly referable to Fimbria in view of its lucinoid dentition and its characteristic lattice ornamentation. The reconstructed hinge structure is able to be formulated: $\frac{\text { AIII } 3 \mathrm{a} 3 \mathrm{~b} ?}{\text { AIV AII } 24 \mathrm{~b} ?}$.

Typical Fimbria appeared already in the Lower Jurassic and survives until Recent without any remarkable transformation of internal and external characters. Since Lower Cretaceous species of Fimbria seem rather rare, the present specimen probably belongs to a new species. However, its specific determination is deferred until more sufficient material is obtained.

Occurrence.-Upper Miyakoan (Albian). Grey fine sandstone of the Yatsushiro formation at loc. Km. 1843, north of Shimofukami, Sakamoto town, Yatsushiro County, Kumamoto Prefecture (Kanmera coll.). 


\author{
Superfamily Cardiacea \\ Family Cardiidae \\ Subfamily Protocardiinae \\ Genus Protocardia BEYRICH, 1845 \\ (=Protocardium auct.)
}

Type-species.-Cardium hillanum SowerBy, 1813, Lower Cretaceous, Europe and ? South America (by Herrmannsen, 1847).

\title{
Subgenus Globocardium nov.
}

Type-species.-Cardium sphaeroideum FoRBES, 1845, Aptian, western Europe and Japan.

Diagnosis.-Strongly inflated Protocardia having globose shell, widely spaced concentric costae on the disk and a nearly smooth posterior area without any conspicuous radial ribs; posterior carina weak or absent; ventral margin smooth internally; hinge similar to that of Protocardia (s. s.).

Remarks.-Protocardia is typically characterized by the presence of conspicuous radial ribs on the posterior area in addition to the concentric ribs on the remaining part. In Protocardia sphaeroidea and several related species from the Cretaceous, however, the posterior radial ribs are almost completely effaced (probably degenerate), and there are only a few internal riblets along the boundary between the disk and the posterior area, which are clearly seen in the Japanese specimens of $P$. sphaeroidea. These differences seem to enable us to distinguish the group from Protocardia (s. s.), although there is no significant difference as to the hinge structure.

In addition to the type-species, the following Cretaceous species are to be referred to this subgenus:

"Lucina" imbricataria DeShaYES, in LEYMERIE, 1842, p. 4, pl. 5, fig. 2 (D'Orbigny, 1844, p. 18, pl. 239, figs. 4-6; Pictet and CAMPiche, 1866, p. 258, pl. 121, figs. 6, 7) from the upper Neocomian of France.

Cardium neckerianum PICTET and Roux, 1852, p. 424, pl. 30, fig. 3, from the Aptian of Switzerland (possibly a synonym of $P$. sphaeroidea).

Protocardia sp., in WooDs, 1908, p. 196, pl. 31, fig. 4, from the Upper Greensand of England.

Protocardia rothpletzi KRENKEL, 1910, p. 216, pl. 21, fig. 1 (DIETRICH, 1933, p. 51, pl. 6, figs. 89-91) from the upper Neocomian of east Africa.

SToLICZKA (1871, p. 213) suggested that Cardium sphaeroideum is a member of Laevicardium. In the globose outline and weak radial ribs this subgenus may be somewhat similar to the Laevicardiinae. However, the former is clearly different from the latter in the presence of strong concentric costae, smooth inner ventral margin and much larger dimensions. This subgenus is certainly unrelated to Laevicardium, but is probably a descendant group from Protocardia (s. s.). 
DIETRICH (1933) proposed "Tendagurium" as a subgenus of Cardium on the basis of two species, i.e. Cardium (Tendagurium) propebanneianum DIETRICH, 1933, from the Upper Jurassic and Protocardia rothpletzi KRENKEL, 1910, from the Neocomian of east Africa. The latter species is, as pointed out by DIETRICH, probably allied to Protocardia sphaeroidea ForBes, 1845, although the concentric ribs are more densely spaced in the former than in the latter. Unfortunately the type-species of "Tendagurium" was not indicated by DIETRICH, and the subgeneric name is not available, because it was proposed after 1930 [ICZN, Rule 13b, 1958, London]. KEEN (1937) subsequently designated C. propebanneianum as the type-species of "Tendagurium". AMANO, OGATA and NIRE (1958) designated again C. propebanneianum as the type-species, and gave a generic diagnosis to "Tendagurium DIETRICH, 1933". They agreed with DIETRICH (1933) in regarding $P$. sphaeroidea as a member of "Tendagurium". However, C. propebanneianum is characterized by the sharply carinated, subtrapezoidal and transversely elongated outline, and at least subgenerically different from $P$. rothpletzi and $P$. sphaeroidea. I presume that $C$. propebanneianum is unrelated to Protocardia. Therefore, the present subgenus is anyhow distinct from "Tendagurium", even if the validity of the latter might be proved.

The present subgenus is probably equivalent to the 3rd group "formes aberrantes" of Protocardia in GILLET's classification (1924), because she included $P$. sphaeroidea and $P$. imbricataria in the group and noted, "Les deux especes doivent descendre de Protocardia normaux par dégénéreséence produisant la disparition des côtes rayonnantes de la région siphonale".

\section{Protocardia (Globocardium) sphaeroidea (FORBES) \\ Plate 16, Figures 1-6}

1845. Cardium sphaeroideum FoRBES, Quart. Jour. Geol. Soc., Vol. 1, p. 243, pl. 2, fig. 8.

1850. Cardium sphaeroideum, D’ORBIGNy, Prodrome de Paléont., Vol. 2, p. 79.

?1852. Cardium neckerianum PICTET and Roux, Moll. Fossil. Grès verts de Genève, p. 424, pl. 30, fig. 3 .

1858. Cardium sphaeroideum, Pictet and Renevier, Matér. Pal. Suisse, Sér. 1, p. 77 , pl. 9 , fig. 3 .

1908. Protocardia sphaeroidea, Woods, Monogr. Cret. Lamell. England, Vol. 2, p. 195 , pl. 31 , figs. 2,3 .

1934. Protocardia sp., NAGAO, Jour. Fac. Sci. Hokkaido Imp. Univ., Ser. 4, Vol. 2, No. 3, p. 228, pl. 29, fig. 13.

1939. Protocardia sphaeroideum, MARLIÈRe, Mém. Mus. roy. d'Hist. nat. Belgique, Mém. No. 89, p. 57, pl. 3, figs. 8a-f. [sic]

1960. Protocardia sphaeroidea, Druschiza and KudrJavtseva, Atlas Low. Cret. Fauna, North Caucasus and Crimea, p. 215, pl. 26, figs. 3-5.

Material.-Seven specimens (GK. H 6478-GK. H 6481, GK. H 6688, GK. H 6689 , GK. H 6788) from the Miyako area (HANAI and HAYAMI coll.) are concerned with the description below.

Description.-Shell large for the genus, suborbicular and subequilateral 
in outline, strongly inflated, never carinated, slightly higher than long; test moderate in thickness; antero-dorsal margin slightly concave, gradually sloping down to the anterior margin; postero-dorsal one comparatively short, straight, nearly as long as antero-dorsal, obliquely truncated by the posterior margin; ventral margin smoothly arcuate; posterior area, which is delimited from the remaining part by the different mode of ornamentation, slightly concave, occupying about one-third of whole surface; umbo very slightly prosogyrous, rising highly above the dorsal margin, placed nearly at the mid-point of length; ligament opisthodetic, external; antero-median surface ornamented with regular flat-topped and broad concentric ribs which are about $2 \mathrm{~mm}$. in breadth, separated from one another by narrow grooves and become denser towards the ventral periphery in the adult shell; concentric ribs almost effaced on the posterior area; posterior area smooth except for faint growth-lines and almost invisible radial threads; a few internal riblets developed along the boundary between the posterior area and the disk, but any other trace of radial ornament imperceptible; muscular impressions subovate, comparatively weak; a pair of remote lateral teeth developed near half ways of the antero- and postero-dorsal margins; cardinal teeth not observable in the present material; ventral margin not crenulated internally; umbonal cavity deep.

Measurements in $\mathrm{mm}$.

$\quad$ Specimen
Right valve (GK.H6478)
Right in. mould (GK.H6479)
Right valve (GK.H6480)
Right valve (GK.H6481)
Right in. mould (GK.H6688)
Both valves (GK.H6689)

$\begin{array}{cccc}\text { Length } & \text { Height } & \text { Thickness } & \text { L/H } \\ 61.0 & 66.5 & 25.5 & 0.92 \\ 38.5 & 40.5 & 14.5 & 0.95 \\ 66.0 & 71.5 & 27.5 & 0.92 \\ 56.5 & 66.0 & 21.5 & 0.86 \\ 67.0 & 72.5 & 29.0 & 0.92 \\ 37.5 & 34.0+ & 19.5+ & 1.10-\end{array}$

Observations and comparisons.-Seven specimens were collected from the Miyako group: three are incomplete right valves and four are internal moulds. The test is well preserved in a specimen (GK. H 6478). They are evidently conspecific with a left valve (IGPS reg. no. 35842) from the same group, which was described by NAGAO (1934) as Protocardia sp. The concentric ribs of NAGA0's specimen appear to be much narrower than those of these specimens, but this is certainly due to the surface erosion.

The present specimens are quite similar to the holotype and other examples of Protocardia sphaeroidea (FoRBES, 1845) from the Aptian of Europe in all the external characters, being probably conspecific with them. Especially the first specimen (GK. H 6478) is quite identical with $P$. sphaeroidea from the Lower Greensand of England (Woods, 1908, pl. 31, figs. 2a, b) in the globose outline, size and concentric ornamentation. The posterior part of this specimen is broken, but the smoothness of the posterior area is well recognized from another specimen (GK. H 6480). Another Lower Greensand specimen illustrated by Woods (1908, pl.31, fig. 3) shows a tall outline, but in the ratio of length/height it is comparable with some of the present specimens. 
Protocardia rothpletzi KRENKEL, 1910, from the Neocomian of east Africa is similar to $P$. sphaeroidiea, but differs from it in the more densely spaced concentric ribs.

Amano, Ogata and Nire (1957) and Amano (1962, p. 14) have considered that a Lower Cenomanian species from Shishijima, named Tendagurium seikaianum, is closely related to Protocardia sp. of NAGAo (1934) and Protocardia sphaeroidea. However, that species seems to be quite different from $P$. sphaeroidea and other species of Globocardium nov. in view of the carinated and subtrapezoidal outline, large ratio of length/height, clearly truncated posterior margin and the mode of concentric ribs which are stronger on the posterior part than on the disk. I presume that the Cenomanian species is more closely related to Integricardium RoLLIER, 1912, than to Protocardia.

Occurrence.-Lower Miyakoan (Aptian). Calcareous sandstone of the Hiraiga formation at loc. Hn. 0001, 0017, southern coast of Hiraiga, and grey sandy shale of the Tanohata formation at loc. Hn. 0220, northern coast of Hiraiga, Tanohata village, Shimohei County, Iwate Prefecture. This species is known also from the Aptian of England, France, the upper NeocomianAptian of Crimea and Caucasus, and the Albian of Belgium.

\author{
Subgenus indetermined \\ Protocardia hiraigensis sp. nov. \\ Plate 15, Figures 8-10
}

1934. Cardium sp., NAGA0, Jour. Fac. Sci., Hokkaido Imp. Univ., Ser. 4, Vol. 2, No. 3, p. 228, pl. 29, fig. 15 (? fig. 7).

Material.-The holotype is a left valve (GK. H 6483) collected from the Hiraiga formation at loc. Hn. 0017, southern coast of Hiraiga, Tanohata village, Shimohei County, Iwate Prefecture (HAYAMI coll.). Paratypes (GK. H 6484, GK. H 6485) from the same locality (HAYAMI coll.).

Description.-Shell small, slightly inequilateral, suborbicular in outline, faintly carinated, nearly as long as high or a little higher than long, strongly inflated; test thin; posterior margin obliquely truncated; umbo prominent, highly protruded above the dorsal margin, placed slightly anteriorly from the mid-point of length; posterior area obscurely delimited from the disk, very slightly concave; surface ornamented with numerous, densely spaced concentric ribs on the disk and numerous fine radial riblets which are weak on the disk but fairly stout on the posterior area; valve margin very finely crenulated internally; crenules somewhat coarser on the posterior margin than on the margin of disk, corresponding with the external radial riblets; adductor scars subequal in size, suborbicular; a pair of lateral teeth of Protocardia-type running subparallel to the antero- and postero-dorsal margins; umbonal cavity deep. 
Measurements in $\mathrm{mm}$.

\begin{tabular}{|c|c|c|c|c|c|c|}
\hline & Specimen & & Length & Height & Thickness & $\mathrm{L} / \mathrm{H}$ \\
\hline Holotype & (GK.H6483) & left valve & 14.0 & 14.5 & 7.0 & 0 . \\
\hline Paratyp & (GK.H6484) & right valve & 16.5 & 17.0 & 7.5 & 0.9 \\
\hline Paratyp & (GK.H6485) & right in. mould & 14.0 & 14.5 & 7.5 & \\
\hline
\end{tabular}

Observations and comparisons.-Although the test of the three present specimens is more or less exfoliated, the external and internal characters except for the structure of the cardinal teeth are exhibited. The strong shell-convexity and general outline may remind one of the immature shells of Protocardia (Globocardium) sph-aeroidea (FORBES, 1845) from the same locality, but the presence of distinct radial ribs on the whole surface, inner marginal crenulations and narrowly spaced concentric ribs on the disk seem to constitute criteria for the distinction of this species from $P$. sphaeroidea. Moreover, the concentric ribs are much finer than those on the umbonal area of $P$. sphaeroidea.

The concentric ribs on the disk are weaker in the present species than in normal species of Protocardia, and the radial riblets are distributed not only on the posterior area but also on the disk. Some species of Protocardia, such as P. morii HAYAMI, 1959, from the Tithonian or Lower Neocomian Jusanhama formation of north Japan possess weak radial ribs on the whole surface, but they are evidently interrupted by concentric ribs on the disk and never continuous as in the present species.

On the other hand, some Lower Cretaceous species of Nemocardium such as "Cardium" ibbetsoni FonBES, 1845, resemble the present species in the radial marking. However, the concentric ornament is probably no more than growthlines in those species. Fine marginal crenulations are commonly seen in Nemocardium but are restricted to the posterior part in most species of Protocardia. In view of these characters the present species is presumably transitional between Protocardia and Nemocardium.

Occurrence.-Lower Miyakoan (Aptian). Calcareous sandstone of the Hiraiga formation at loc. Hn. 0017, southern coast of Hiraiga, Tanohata village, Shimohei County, Iwate Prefecture. NAGAO (1934) described the present species as Cardium sp. from Hideshima, Miyako City, the same prefecture.

\section{Genus Nemocardium MEEK, 1876}

Type-species.-Cardium semiasperum DeshaYes, 1860, Eocene, Europe (designated by SACC0, 1899).

Nemocardium yatsushiroense sp. nov.

Plate 17, Figures 1-7

Material.-The holotype is a right internal mould (GK. H 6486) collected from the Yatsushiro formation at loc. Hy. 1012, Nekodani, Yatsushiro City, Kumamoto Prefecture. Paratypes (GK. H 6487-GK. H 6478, GK. H 6690, GK. H 6691, GK. H 6695) from the same locality (HAYAMI coll.), and paratypes 
(GK. H 6692-GK. H 6694) from the same area (KANMERA and FUJII coll.). Description.-Shell medium- or large sized for the genus, equivalve, fairly inequilateral, trigonally orbicular in outline, slightly expanded postero-ventrally, weakly carinated both in the anterior and posterior areas, moderately inflated, nearly as long as high; test comparatively thin; maximum length lies slightly beneath the mid-height; umbo placed submesially, incurved, rising highly above the dorsal margin, moderate in breadth, orthogyrous or slightly prosogyrous; anterior and posterior margins gently arcuate without any striking angulation; a pair of weak carinae, which are more or less conspicuous on the umbonal region, divide surface into anterior, median and posterior areas; posterior part slightly concave behind the carina and flattened near the periphery; surface wholly marked with about 150 fine simple radial riblets, which are slightly broader than their interspaces; radials somewhat roughly spaced and slightly strengthened on the posterior area, slightly reticulated but never spinose; difference of the prominence of the radials become conspicuous towards the ventral margin; concentric ribs absent; growth-lines very weak; ventral margin finely crenulated in the disk and more roughly in the posterior part in accordance to the radial riblets; hinge plate comparatively narrow, not much elongated; dentition as formulated: $\frac{\text { AI } 3 \mathrm{a} 3 \mathrm{~b} \text { PI }}{\text { AII } 24 \mathrm{~b} \text { PII }} ; 2$ and $3 \mathrm{~b}$ conical, overhanging respectively the sockets $3 \mathrm{~b}^{\prime}$ and $2^{\prime}$; $3 \mathrm{a}$ and $4 \mathrm{~b}$ much smaller, obscurely delimited from the hinge plate; anterior lateral teeth stronger than the posterior ones in each valve; AI and PI more or less elongated, not very thick but highly elevated; musculature obscure; umbonal cavity profound.

Measurements in mm.
Specimen*
Holotype (GK.H6486)
right in. mould
Paratype (GK.H6487) right in. mould
Paratype (GK.H6488) left in. mould
Paratype (GK.H6489) left in. mould
Paratype (GK.H6690) left in. mould
Paratype (GK.H6691) left ex. mould
Paratype (GK.H6692)
right in. mould
Paratype (GK.H6693) right valve
Paratype (GK.H6694) left valve
Paratype (GK.H6695) left in. mould

$\begin{array}{cccl}\text { Length } & \text { Height } & \text { Thickness } & \text { L/H } \\ 44.0 & 44.5 & 12.5 & 0.99 \\ 40.5 & 43.0 & 12.0 & 0.94 \\ 40.5 & 40.5 & 10.5 & 1.00 \\ 47.5 & 44.5+ & 13.5 & 1.07- \\ 37.5 & 39.5 & ? & 0.95 \\ 37.0+ & 43.0 & 10.5 & 0.86+ \\ 44.0 & 41.0+ & 11.0 & 1.07- \\ 35.0 & 42.0 & 14.0 & 0.83 \\ 26.0 & 29.5 & 10.0 & 0.88 \\ 37.5 & 41.0 & 10.5 & 0.91\end{array}$

Observations and comparisons.-Many internal and a few external moulds of two valves are at hand. The test is almost exfoliated or replaced by carbonaceous substance, but the characteristic radial ornamentation is preserved on the external moulds and on the replaced shells. Owing to the argillaceous matrix, the shell is frequently secondarily deformed, the pre- and post-umbonal carinae emphasized in some specimens. The original outline is difficult to be completely restored, but it seems to be roughly shown by the four specimens

\footnotetext{
* All the specimens are deformed secondarily.
} 
(GK. H 6486-GK. H 6489). The radial ribs are weakly impressed on all the internal moulds, and the ventral crenulations and posteriorly strengthened radial ribs are recognized in many specimens. In view of the smoothness of anterior umbonal region, the boundary of ornamentation between the posterior part and the remainder may be more distinct in the early stage.

Many cardiids with posterior radial ribs from the Rhaetian, Jurassic and Cretaceous have been referred to Protocardia BEYRICH, 1845, but the present species cannot be included in the genus owing to the presence of inner marginal crenulations, numerous fine radial riblets on the whole surface and the absence of concentric ribs on the disk. These characters agree better with those of Nemocardium MeEk, 1876.

The posterior radials of Nemocardium (s. s.) are fairly strong and possess numerous spiny projections. In comparison with typical species of Cenozoic and Recent species of Nemocardium (s. s.), the posterior radial ribs are weaker and worse defined from the antero-median ones in the present species, as usual in many Cretaceous species. In this respect it may be closer to Arctopratulum KEEN, 1954 (type-species: Nemocardium (Arctopratulum) griphus KEEN, 1954) from the Upper Oligocene and Miocene of northern Pacific region. KEEN referred three Japanese Oligocene species, $N$. ezoense TAKEDA, 1953, $N$. tristiculum (Yokoyama) and N. yokoyamai TAKedA, 1953, to the subgenus. In comparison with hitherto known species of Arctopratulum, however, the outline is less triangular and the radial ribs are distinctly more in number in the present species. The umbo is a little broader than in typical Arctopratulum.

Keenaea HABE, 1951 (type-species: Cardium samarangae MAKIYAMA, 1934) and Pratulum IREDAle, 1924 (type-species: Cardium thetidis Hedley, 1902) are regarded as other subgenera of Nemocardium. Keenaea seems to be characterized by the reticulated posterior ribs. In the present species reticulation is very slight, the ratio of length/height is distinctly smaller and the dimensions are generally much larger than in the type-species of Keenaea. Although the Miocene-Pliocene fossil specimens of $N$. $(K$.$) samarangae from the Miyazaki$ group (SHUTo, 1960) are somewhat taller than the Recent specimens and comparable with the present species also in the dimensions, the umbonal area is less salient than in the present species.

Nemocardium is generally considered to have been originated from Protocardia. The derivation of the former from the latter may have taken place in the Lower Cretaceous. Although the pre-Tertiary species of the Cardiidae have not been satisfactorily classified, there are several Cretaceous species of "Cardium" which have been or can be referred to Nemocadium by the characteristic ornamentation. "Cardium" subhillanum D'ORBIGNY, 1843, from the Neocomian of France, and "Cardium" bisolaris CRAGIN, 1894, from the Upper Cretaceous of Texas, were assigned to this genus respectively by MEEK (1876) and STEWART (1930).

Furthermore, Cardium ibbetsoni FoRBEs, 1845, Cardium cottaldium D'ORBIGNY, 1844, Cardium raulinianum D'ORBIGNY, 1844, Cardium voltzi LEYMERIE, 
1842, and some other species from the Lower Cretaceous of Europe show similar ornamentation. In most cases, however, the hinge structure and mode of ventral crenulations have not been described. I do not venture to discuss their generic position, but the comparison of the exterior between the present species and some foreign species is noted below.

So far as I observed Woons' illustration and description (1908), the present species is similar to Cardium ibbetsoni from the Lower Greensand of England in the prominent umbo, weak posterior carina and numerous fine radial riblets on the whole surface, but the shell is by far larger (about three times), and the shell-convexity appears slightly weaker than in that species. CASEY (1961) referred $C$. ibbetsoni to the subgenus Pratulum in his list of Lower Greensand fossils, but the present species is never a member of Pratulum, because the outline is not subquadrate and fine wavy concentric sculpture of Pratulum-type is absent at all in the present species. It differs from Cardium cottaldium D'ORBIGNY, 1844, from the Neocomian of France, in the more rounded outline, more numerous radial riblets and better delimited posterior area, although some Mexican specimens compared with $C$. cottaldium by ALENCASTER (1956) are similar to it in the outline.

Nemocardium (Nemocardium) dumbeae FrenEIX, 1958, from the Senonian of New Caledonia has less prominent umbo and weaker carinae than the present species. Protocardia denisonensis (CRAGIN, 1894) from the lower Albian of Mexico and Texas (Perkins, 1960) may be also a member of Nemocardium, but the size is much larger than in the present species.

It is concluded that most of Cretaceous species of Nemocardium including the present species bear some affinities to Nemocardium (s. s.), Arctopratulum, Pratulum or Keenaea, but can be referred to none of them with a certain confidence. If the much earlier occurrence of these species than the typespecies of those subgenera is also taken into consideration, they might be ultimately separated subgenerically from hitherto proposed taxa.

Occurrence.-Upper Miyakoan (Albian). Grey sandy shale of the Yatsushiro formation at loc. Hy. 0012, north of Nekodani, Yatsushiro City, Kumamoto Prefecture. Grey fine sandstone of the same formation at loc. Km. 3037, west of Mt. Jogusan, Miyaji, Yatsushiro City.

Subfamily Laevicardiinae

Genus Laevicardium SwaINson, 1840

Type-species.-Cardium oblongum GMELIN, 1790, Recent (designated by STOLICZKA, 1871).

Laevicardium (?) ishidoense (YABE and NAGAO)

Plate 17, Figures 8-10

1926. Cardium ishidoense YABE and NAGAO, in YABE, NAGAO and SHIMIZU, Sci. Rep. Tohoku Imp. Univ., Ser. 2, Vol. 9, Pt. 3, p. 48, pl. 12, figs. 9, $16,18$. 
1954. Cardium ishidoense, Matsumoto, Cret. System, Japan. Islands, p. 115, listed (pars).

Material.-A right valve (IGPS reg. no. 22533) illustrated by YABE, NAGA0 and SHIMIZU (1926, pl. 12, fig. 18) is designated here as the lectotype. It was collected from the Ishido formation at Ishido, Ohinata village, Minamisaku County, Nagano Prefecture. Other syntypes are broken and strongly deformed, but are probably conspecific with the lectotype. Five more specimens (GK. H 6188-GK. $H$ 6192) from the Yatsushiro area (AKATSU and KANMERA coll.) are concerned with the description below.

Description.-Shell medium-sized for Laevicardium, equivalve, inequilateral, subtrigonal-ovate, elongated postero-ventrally, much hgher than long, strongly inflated; test rather thin; umbo slightly prosogyrous, incurved, placed slightly anteriorly from the mid-point of length, rising highly above the dorsal margin; antero-dorsal margin short, slightly concave; postero-dorsal margin much longer than the antero-dorsal, rectangularly truncated; ventral margin gently arcuate, though the curvature is strong near the junction with the posterior margin; antero-dorsal area slightly flattened; anterior and posterior carinae hardly discernible; surface wholly marked with numerous fine radial riblets which are conspicuous on the middle part of the shell and become more obscure towards the antero-dorsal and postero-dorsal peripheries; ventral margin finely crenulated internally in accordance with the radial ornamentation; anterior lateral tooth of cardiid-type placed near the antero-dorsal angle; cardinal teeth 2 and $3 b$ conical, while $3 \mathrm{a}$ and $4 \mathrm{~b}$ are very small and poorly defined from the hinge plate; musculature unknown; umbonal cavity deep.

\section{Measurements in $\mathrm{mm}$.}

$\quad$ Specimen
Left valve (GK.H6191)
Left in. mould (GK.H6192)
Right in. mould (GK.H6188)

$\begin{array}{cccc}\text { Length } & \text { Height } & \text { Thickness } & \text { L/H } \\ 25.5 & 33.5 & 13.5 & 0.76 \\ 14.5 & 18.0 & 6.5 & 0.81 \\ 16.0 & 21.0 & 7.0 & 0.76\end{array}$

Observations and comparisons.-Three specimens measured above seem to retain the original outline of this species. In addition, two poorly preserved internal moulds (GK. H 6189, GK. H 6190) show a part of hinge structure, but the ratio of length/height is much increased and the posterior carination more or less emphasized owing to the strong secondary deformation. Although the test is almost eroded away in every specimen, numerous fine radial riblets and marginal crenulations are clearly impressed on the internal mould. The largest specimen has more or less broader posterior area and stronger shellconvexity than other ones, but the difference may be due to the secondary deformation.

Because all the syntypes of Cardium ishidoense from the Sanchu area are strongly deformed or crushed, it is rather difficult to recognize the original outline and other specific characters of this species. However, in the posteroventrally expanded shell, prominent umbo, number of radial riblets and some- 
what angulated postero-dorsal margin the present specimens are similar to the syntypes, and are provisionally referred to C. ishidoense. Cardium corpulentum A.MANO, 1957, from the Hagino formation of Shikoku is also similar to this species, but the shell is not so elongated postero-ventrally and the umbonal angle distinctly larger than in the present specimens.

YABE and NAGAO compared the present species with Cardium remondianum GABB, 1864, from the Upper Cretaceous of California, which was questioningly referred to Pachycardium by STEWART (1930). If compared with STEWART's figure of GABB's type specimen, the present species is quite different from that species both in the outline and ornamentation. Cardium sp. in Woods (1908, p. 205, pl. 32, figs. 17a-c) from the upper Chalk of England shows a similarly elongated outline, strong shell-convexity and weak radial riblets distributed on the whole surface. It is possible that the present species is congeneric with that, but the more flattened posterior area suggest that it is at least specifically distinct from the Chalk species.

The present species probably belongs to an unnamed genus of the Laevicardiinae. Pachycardium CoNRAD, 1869 (type-species: Cardium spillmani CONRAD, 1858) having also subvertically elongated outline is known from the Cretaceous of the Gulf Coast. In P. spillmani (CoNRAD) (SHIMer and SHrock, 1944, pl. 169, fig. 11) and P. stantoni (WADE, 1926), however, the test is much thicker, the hinge heavier and the umbo less salient than in the present species. The anterior area of Pachycardium is characteristically widely flattened.

In the weak radial ornamentation the present species is a remniscent of Laevicardium SwAINSON, 1840, but it is not typical of the genus, because the posterior area is somewhat flattened and the umbo is highly protruded above the dorsal margin. The generic reference of the present species is provisional.

Occurrence.-Aritan to upper Miyakoan (upper Neocomian to Albian). Grey sandy shale of the Yatsushiro formation at loc. Km. 1843, north of Shimofukami, Sakamoto town, Yatsushiro County, Kumamoto Prefecture. Grey fine sandistone of the same formation at loc. At. 828A, south of Bisho, Toyo village, the same county. The present species was originally described from the Ishido formation at Ishido, Ohinata village, Minami-saku County, Nagano Prefecture.

\section{Laevicardium (?) corpulentum (AMANo)}

Plate 15, Figure 11

1957. Cardium corpulentum Amano, Kumamoto Jour. Sci., Ser. B, Sec. 1, Vol. 2, No. 2, p. 99, pl. 2, fig. 30.

Material.-The holotype is a left internal mould* (GT. KML-0004) illustrated by AMANo (1957, pl.2, fig. 30). It was collected from the Hagino formation at Hagino, Mirafu village, Kami County, Kochi Prefecture. This species is represented in the present collection only by a poorly preserved left

* Amano regarded the specimen as a right internal mould, but it is evidently erroneous. 
internal mould (GK. H 6696) from the type locality (OGAWA coll.).

Remarks.-Because the present specimen (left internal mould, GK. H 6696, $19.5+\mathrm{mm}$. long, $25.0+\mathrm{mm}$. high, $12.0+\mathrm{mm}$. thick) is poorly preserved, nothing can be added to the specific characters which were described by Amano. This species is presumably congeneric with Laevicardium (?) ishidoense (YABE and NAGA0, 1926) from the Sanchu and Yatsushiro areas, and is also referred to Laevicardium with a query.

Occurrence.-Lower Miyakoan (Aptian). Weathered sandstone of the Hagino formation at loc. Hy.6011, Hagino, Mirafu village, Kami County, Kochi Prefecture.

\author{
Superfamily Tellinacea \\ Family Icanotiidae \\ Genus Scittila CASEY, 1961
}

Type-species.-Scittila nasuta CASEY, 1961, Aptian, England (original designation) (=Tellina carteroni Woods, 1907, ? non D'ORBIGNY, 1845). CASEY proposed this genus on the basis of WooDs' specimen of " $T$. carteroni", which was provisionaily regarded as a distinct species from D'ORBIGNY's in order to avoid the uncertainties as to the characters of type-species.

\title{
Scittila japonica sp. nov.
}

Plate 18, Figure 1

\section{Compare.-}

1957. “Tellina” aff. carteroni D'ORBIGNY, Amano, Kumamoto Jour. Sci., Ser. B, Sec. 1, Vol. 2, No. 2, p. 102, pl. 1, fig. 26.

Material.-The holotype is an internal mould of two valves (GK. H 6533) from the Hanoura formation at loc. Hy. 5003, Hiroyasu, Katsuura town, Katsuura County, Tokushima Prefecture (HaYami coll.). Paratype (GK. H 6534) from the same locality (HAYAMI coll.).

Description.-Shell medium-sized, elongate-rhomboidal, inequilateral, about three times longer than high, weakly inflated; test probably thin; antero-dorsal margin straight or slightly concave; postero-dorsal margin straight, turned to the prosocline siphonal margin with an obtuse angle; postero-ventral extremity pointed; umbo not prominent, unusually broad, slightly prosogyrous, placed more or less anteriorly from the mid-point of length; a sharp carina, which is strongly curved downwards, extending from the umbonal area to the posteroventral extremity, delimiting clearly a narrow postero-dorsal slope; disk marked with about a dozen of broad concentric plications; radial ribs apparently absent or very weak; a faint shallow furrow extending from the umbo to the middle portion of the ventral margin, constricting the shell; hinge and other internal characters unknown. 
Measurements in $\mathrm{mm}$.

\begin{tabular}{|c|c|c|c|c|c|c|}
\hline & Specimer & & Length & Height & Thickness & $\mathrm{L} / \mathrm{H}$ \\
\hline Holoty & (GK.H6533 & left in. mould & 37.5 & 13.0 & 3.0 & 2.88 \\
\hline Holotype & (GK.H6533 & right in mould & 38.5 & 12.5 & 3.0 & 3. \\
\hline
\end{tabular}

Observations and comparisons.-The holotype is nearly complete in outline, but the test is completely eroded away. The dimensions of the two valves of the holotype are slightly different owing to the weak secondary deformation. Concentric plications are clearly impressed on the internal moulds, but no radial sculpture is recognizable even on the posterior part. The paratype is fragmentary but shows similar concentric plications to the holotype. The presence of a sharp posterior carina is recognized in the two specimens.

Such a shell as the present species was accustomally treated as "Tellina" by many palaeontologists. The general aspect of the external characters is, in fact, similar to that of Phylloda ScHMACHeR, 1817 (type-species: $P$. aurea Schmacher) of the Tellinidae, as pointed out by Amano (1957, p. 102). However, CASEY (1961) clarified the hinge structure of "Tellina carteroni" of Woods (1907), and proposed Scittila as a genus of his family Icanotiidae. It is generally presumed that the Icanotiidae (and probably also Tellinidae) were derived from some Jurassic species of the Tancrediidae.

The present species is certainly congeneric with Tellina carteroni D'ORBIGNY, 1845, and Scittila nasuta CASEY, 1961, from the Aptian of western Europe, because the outline and posterior carination are quite similar. Compared with the Lower Greensand specimens of S. nasuta, however, the umbo is placed slightly more anteriorly and the shell is more transversely elongated in the present species. Weak radial ribs are known on the surface of T. carteroni and $S$. nasuta, but apparently absent in the present specimens. Concentric plications seem to be more regular and more widely spaced in the present species than in the two European species.

"Tellina" aff. carteroni of AMANo (1957) from the Hagino formation of Shikoku may be conspecific with the present specimens, but the specific identity cannot be warranted owing to the different state of preservation. The hinge nature of the Hagino species, as shown by Amano (1957, p. 102, fig. 3), is essentially similar to that of $S$. nasuta CASEY (1961, pl. 80, figs. 1, 2).

Occurrence.-Aritan (upper Neocomian). Dark grey fine sandstone of the Hanoura formation at loc. Hy. 5003, Hiroyasu, Katsuura town, Katsuura County, Tokushima Prefecture.

Scittila sp. indet.

Plate 19, Figure 11

There is a right valve resembling Scittila japonica sp. nov. in the sharp posterior carination and surface characters. It is probably distinct from that species, because the shell is much shorter and the posterior area is narrower than the holotype of $S$. japonica. The outline is more closely related to that 
of Scittila nasuta CASEY, 1961 (=Tellina carteroni of WooDs, 1907) from the Lower Greensand of England, but its specific determination is difficult at present. The illustrated specimen, right valve, GK. H $6710,26.5 \mathrm{~mm}$. long, $13.5 \mathrm{~mm}$. high, $3.5 \mathrm{~mm}$. thick.

Occurrence.-Aritan (upper Neocomian). Dark grey sandy shale of the Hanoura formation at loc. Hy. 5001, Hiroyasu, Katsuura town, Katsuura County, Tokushima Prefecture (HAYAMI coll.).

\section{Suborder Pliodontina \\ ? Superfamily Arcticacea \\ Family Neomiodontidae}

Remarks.-The Neomiodontidae, which were proposed by CASEY (1955), include a number of so-called cyrenoids from the Jurassic and Cretaceous marine-brackish and brackish-fresh water sediments of the Tethyan province, western Europe, Japan and Mexican region. CASEY (1955) originally referred Neomiodon FISCHER, 1887 (=Protomiodon ANDERSON and Cox, 1947), Eomiodon Cox, 1935, Myrene CASEY, 1955, Cyrenopsis ETHERIDGE Jr., 1902, and Musculiopsis MacNeIL, 1939, to the Neomiodontidae. In addition, I think that Protocyprina VoKes, 1946 (?=Amphiaraus VoKes, 1946), Pseudasaphis Matsumoto, 1938, Crenotrapezium HAYAMI, 1958, and Costocyrena (MATsumoto and KANMERA MS) nov. are distinct genera of the family. Mesocorbicula SUZUkI and OYama, 1943 (type-species: Corbicula tetoriensis KoBayashi and SUzukI, 1937), may be a synonym of Neomiodon.

The Neomiodontidae have been generally referred to the Arcticacea. As to the systematic position of this family, CASEY (1955, pp. 209-211) noted, "The distinctive feature of the Neomiodontidae is the combination of a simple lucinoid cardinal dentition with long, corbiculoid laterals, in contrast to the cyprinoid level of cardinal development attained by the Arcticidae. The morphology of the cardinal teeth, with tendency to development of the tooth $5 b$, is remniscent of the Astartacea rather than the Arcticacea, and it is interesting to note that in its external features the genus Eomionlon strongly recalls Astarte and its allies. Possibly the Neomiodontidae lie near the common root of the Astartacea and the Arcticacea."

CASEY's opinion on the phylogeny of this family seems to be well endorsed by the common occurrence of this family from the Lower Jurassic of Japan. Crenotrapezium kurumense and its allies (HAYAMI, 1958, etc.), from the Lower Jurassic of central and west Japan, are undoubted species of the Neomiodontidae. Eomiodon is also well represented by several species in the Lower Jurassic of north Japan (YoKoYama, 1904; HAYAmI, 1958). Therefore, the origin of the Neomiodontidae should be traced back to the Lowest Jurassic or even to the Triassic, when the early representatives of the Arcticacea still have dentitions of lucinoid level. The cardinal tooth 1 is absent at all in every species of the Neomiodontidae, and it is impossble that this family was derived from 
advanced species of the Arcticidae whch are provided with cyprinoid or cyrenoid dentition.

I think that the Neomiodontidae are separable into two subfamilies, as suggested before (HAYAMI in HAYAMI and NAKAI, 1965). One is the subfamily Neomiodontinae CASEY, 1955, including Neomiodon, Myrene and Crenotrapezium, and the other is Eomiodontinae nov. including Eomiodon, Protocyprina, Pseudasaphis and Costocyrena nov.

\section{Subfamily Eomiodontinae nov.}

Type-genus.-Eomiodon Cox, 1935 [non Eomiodon Chavan, 1936 (=Miodomeris Chavan, 1938)].

Diagnosis.-Shell commonly medium- or large-sized, provided with clearly impressed lunule and escutcheon; posterior carina indistinct or absent; surface marked with concentric ribs which are often restricted to the umbonal region as in Astarte (s. s.) ; radial ribs may or may not be present; hinge characterized by the combination of astartoid cardinal teeth and corbiculoid elongated lateral teeth, commonly formulated as below:

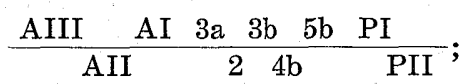

cardinal tooth $5 \mathrm{~b}$ distinctly separated from the nymph; lateral tooth PIII commonly absent; pallial line not sinuate but bent more or less abruptly below the posterior adductor.

Remarks.-In contrast to the Eomiodontinae nov. defined above, the nominative subfamily Neomiodontinae are generally characterized by the more or less conspicuous posterior carination, the absence of well delimited lunule, the absence or weakness of the cardinal tooth $5 \mathrm{~b}$, the distinctly separated lateral tooth PIII and the smoothly arcuate pallial line. Astarte-like concentric ribs are rather scarcely met with in the Neomiodontinae. The hinge of the Neomiodontinae appears to be less constant than that of the Eomiodontinae, but generally characterized by the combination of simple lucinoid cardinal teeth and corbiculoid (often cross-striated) lateral teeth, as formulated:

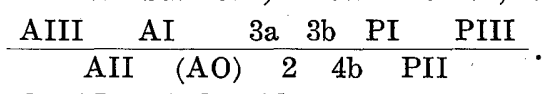

The ancestry of the Neomiodontidae is not as yet very clear. However, as suggested before (HAYAMI, 1962, p. 72), the Neomiodontinae, especially Crenotrapezium HAYAMI, 1958, resembles Eotrapezium DouvILLÉ, 1904 (typespecies: Mesodesma germari DuNken, 1851) from the Lowest Jurassic of Europe, which has been regarded as a primitive group of the Arcticacea, not only in the external features but also in the dentition. Although the cardinal tooth $3 \mathrm{a}$ is more clearly differentiated from AIII in Crenotrapezium than in Eotrapezium, the latter is considered to be a collateral ancestor of the former. In view of the external and internal characters, the Eomiodontinae, as suggested by CASEY (1955), are evidently more closely related to the Astartidae than to the Arcticidae. The well developed cardinal tooth $5 \mathrm{~b}$, the distinctly demarcated lunule and the concentric sculpture suggest that Eomiodon was derived from 
some species of the Astartidae. Although some authors stated without any solid evidence that Eomiodon is ancestral to Neomiodon, I regard that the two genera belong to distinct phylogenetical trunks which evolved in parallel from the Lower Jurassic to the Lower Cretaceous.

If the Neomiodontidae had dual origin, it might be more reasonable to rank up the group of Eomiodon to a distinct family. However, the morphological difference between the Astartacea and the Arcticacea was not so significant in the Triassic and the Lower Jurassic as in later stages.

The apparent resemblance of the elongated and frequently serrated corbiculoid lateral teeth between the Neomiodontidae and the Corbiculidae may constitute a case of homoeomorphism and be attributed to the adaptation of organisms to a similar environment, because the two families are considered to be phylogenetically unrelated. As CASEY (1955a) showed that a part of the Corbiculidae was derived from Eocallista, I maintain that the Corbiculidae was originated from an advanced species of the Arcticidae which has a dentition of cyprinoid or even cyrenoid level. It is also supported there is no corbiculoid possessing the hinge of cyprinoid level characterized by an embryonal cardinal tooth 1 .

The Eomiodontinae prospered especially in the Jurassic and Cretaceous of Japan. Eomiodon itself is one of the most ubiquitous genera in the Jurassic cyrenoid beds. Although Lower Cretaceous species of Eomiodon has not been recorded from Japan, "Astarte" sakawana KoBAYASHI and SUZUKI, 1939, and a few related species to it from the Kochian (lower Neocomian) series certainly belong to this genus. Protocyprina VoKes, 1946 (type-species: Astarte libanotica FrAAs, 1878), which was regarded by CASEY (1955) as a subjective synonym of Eomiodon, occurs also commonly in the Kochian of Japan (HAYAMI and NAKAI, 1965). It is regarded here as a distinct genus of the Eomiodontinae, and as a descendant of Eomiodon.

In Japan, moreover, two radially ribbed cyrenoids have been known to occur commonly from certain Cretaceous brackish-water beds. One of them is Pseudasaphis japonicus Matsumoto, 1938, from the Cenomanian and Turonian Gosyonoura group of west Japan, and the other is "Cyrena" radiatostriata YABE and NAGAO in YABE, NAGAO and SHIMIZU, 1926, which is included here in the genus Costocyrena (MATsumoto and KANMERA MS) nov. Because the hinge structure of Pseudasaphis and Costocyrena is almost indistinguishable from that of Eomoidon, I refer the two genera also to the Eomiodontinae.

Myrene CASEY, 1955 (type-species: Myrene fittoni CASEY, 1955) is said to possess an embryonal cardinal tooth $5 \mathrm{~b}$ and is somewhat similar to Eomiodon in the hinge structure. However, all the other essential characters seem to be more similar to Neomiodon, and Myrene can be regarded as an aberrant group derived from the main stock of the Neomiodontinae.

Genus Costocyrena (Matsumoto and Kanmera, 1952, MS) nov.

Type-species.-Costocyrena matsumotoi sp. nov., Albian, Japan. 
Diagnosis.-Shell medium-sized for the family, equivalve, inequilateral, trigonally ovate or subcuneiform, weakly carinated; umbo prosogyrous, placed anteriorly from the mid-point of length; lunule large, shallow, nearly smooth, clearly delimited by a shallow furrow; surface marked with numerous radial riblets which are often interrupted by prominent concentric lamellae; hinge quite similar to that of Eomiodon, provided with a small but distinct posterior

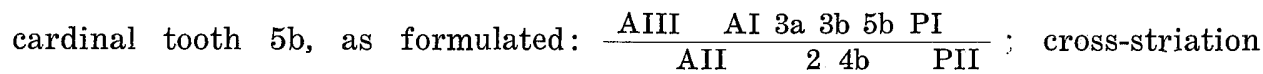
undeveloped on lateral teeth; ventral margin smooth internally.

Remarks.-It has long been known that a radially ribbed unique cyrenoid occurs from the Lower Cretaceous of the Sanchu, Yatsushiro and a few other areas of Japan. YABE and NAGAO in YABE, NAGAO and SHIMIzU (1926) named it Cyrena radiatostriata. MATSUMoto and KANMERA (1952, pp. 44, 50) intended to introduce a subgeneric name Costocyrena, for "C. radiatostriata" from the Hinagu and Yatsushiro formations of Kyushu, but the subgeneric diagnosis and characters have not been given. YABE and NAGAO described the outline and surface sculpture of the Sanchu specimens in detail, but did not mention the hinge structure. The taxonomic position of this species, therefore, has not been clarified.

Fortunately, the hinge and other internal structures are clearly observable in some internal moulds of $C$. radiatostriata and also in many specimens from the Yatsushiro formation named here Costocyrena matsumotoi sp. nov. It is here concluded that these two species certainly belong to the Neomiodontidae instead of the Corbiculidae. On this occasion I propose the application of the tribal name, Costocyrena, as a new genus of the former family.

Cyrena paradoxa SteinmanN, 1881, from the Albian of South America has similar radial striations on the surface, but I have not heard such radial ornaments to exist in other foreign cyrenoids. Proposing the family Neomiodontidae, CASEY (1955, p. 209) mentioned the smooth or concentrically ornamented surface as one of the family characters. Radial ribs are in fact absent in the hitherto referred genera to the family, i.e. Neomiodon, Cyrenopsis, Eomiodon, Musculiopsis, Protocyprina, Myrene and Crenotrapezium.

Pseudasaphis japonicus Мatsumoto, 1938, from the Cenomanian and Turonian Gosyonoura and Mifuné groups of Kyushu, is also a radially ribbed curious cyrenoid. Its cardinal and lateral teeth are fairly similar to those of the present genus. Pseudasaphis was probably derived from Costocyrena, and also can be regarded as a specialized group of the Neomiodontinae. P. japonicus possesses, however, very conspicuous radial ribs of two orders of prominence, which are quite different from the radial riblets of Costocyrena. Concentric lamellae are, on the contrary, much stronger in Costocyrena than in Pseudasaphis.

If the peculiar radial ornamentation is ignored, all the essential characters of the present genus are very similar to those of Eomiodon Cox, 1935 (typespecies: Eomiodon indicus Cox, 1935). It agrees with typical species of Eomiodon such as $E$. indicus Cox, 1935, from the Bathonian of India, $E$. 
Table 1. Diagnostic characters of the Neomiodontinae and Eomiodontinae

\begin{tabular}{|l|l|l|}
\hline & \multicolumn{1}{|c|}{ Neomiodontinae CASEY, 1955 } & \multicolumn{1}{c|}{ Eomiodontinae nov. } \\
\hline genera & $\begin{array}{l}\text { Neomiodon FISCHER, 1887 } \\
\text { Cyrenopsis ETHERIDGE Jr., 1902 } \\
\text { Musculiopsis MACNEIL, 1939 } \\
\text { Myrene CASEY, 1955 } \\
\text { Crenotrapezium HAYAMI, 1958 }\end{array}$ & $\begin{array}{l}\text { Eomiodon Cox, 1935 } \\
\text { Pseudasaphis MATSUMOTo, 1938 } \\
\text { Protocyprina VokES, 1946 } \\
\text { Costocyrena nov. }\end{array}$ \\
\hline posterior carina & conspicuous & commonly inconspicuous \\
\hline Iunule & not impressed & clearly demarcated \\
\hline concentric ribs & distributed on the whole surface, if present & frequently restricted to umbonal area \\
\hline radial ribs & absent & sometimes present \\
\hline dentition formula & AIII AI 3a 3b PI (PIII) & AIII AI 3a 3b 5b PI \\
\hline cardinal tooth 5b & absent or undeveloped & AII \\
\hline lateral tooth PIII & commonly present & distinctly separated from nymph \\
\hline pallial line & smoothly arcuate & not demarcated from margin \\
\hline shell size & small or medium & bent somewhat abruptly \\
\hline habitat & brackish- or fresh-water & medium or large \\
\hline ancestry & primitive species of the Arcticidae & marine or brackish-water \\
\hline
\end{tabular}


cuneatus (Sowerby, 1826) from the Portlandian of England (CASEY, 1955) and also with E. lunulatus. (YokoYama, 1904) and E. vulgaris HaYAMI, 1958, from the Lower Jurassic of Japan, in the presence of well-defined large lunule and escutcheon, more or less cuneiform outline, prosogyrous umbo and concentric lamellae. The dentition is also essentially similar to that of Eomiodon, and the presence of well delimited cardinal tooth $5 \mathrm{~b}$ and undeveloped lateral tooth PIII suggest the intimate relationship between Eomiodon and the present genus. Judging from the stratigraphic occurrences of Eomiodon and Costocyrena, the latter may have been derived from the former in early Cretaceous times.

In the Sanchu and Yatsushiro areas purely marine fossils such as Nanonavis, Pterotrigonia, Neithea and Astarte occur in the sub- and superjacent beds, but are never found in the Costocyrena beds. Futhermore, some ostreids and corbiculids are frequently found in association with Costocyrena. All the facts indicate that Costocyrena favoured certain conditions of more or less unstable salinity such as estuaries or profound embayments. The habitat seems to be similar to that of Eomiodon, the mode of occurrence of which was noted by Cox (1935), Cox and Maubeuge (1950), CaSey (1955) and Hayami (1958, 1961).

The occurrence of the present genus so far known is restricted to the Aritan and Miyakoan (upper Neocomian-Albian) of Japan, unless "Cyrena" paradoxa SteinmanN, 1881, from the Albian of Peru is congeneric. YABE, NAGAo and SHIMIZU (1926) regarded C. radiatostriata as an element of the Ryoseki fauna, but the fossil beds in question should be allocated at Aritan (upper Neocomian) or even at Miyakoan (Aptian-Albian).

'Three species of Costocyrena are distinguishable in the present collection: they are $C$. radiatostriata (YABE and NAGA0, 1926), C. matsumotoi sp. nov. and $C$. sp. aff. C. radiatostriata. Because the internal and external characters are best shown in the specimens of $C$. matsumotoi, it is designated as the type-species of this new genus.

\section{Costocyrena matsumotoi sp. nov.}

Plate 18, Figures 2-12

1952. Polymesoda (Costocyrena) radiatostriata, MATsumoto and KANMERA, Guide book of the geol. excursions: The lower valley of the Kuma, pp. 44, 50, listed. (non Cyrena radiatostriata YABE and NAGAo, 1926)

1954. Polymesoda (Costocyrena) radiatostriata, MAtsumoto, Cretaceous System, Japan. Islands, pp. 112, 115, listed (non Cyrena radiatostriata YABE and NAGA0, 1926).

Material.-The holotype is a right external mould (GK. $\mathrm{H}$ 6502) collected from the Yatsushiro formation at loc. Hy. 0017, Miyaji, Yatsushiro City, Kumamoto Prefecture (HAYAMI coll.). Five paratypes (GK. H 6503-GK. H 6507) from the type locality (HAYAMI coll.) and eight other paratypes from the same area (KANMERA and FUJII coll.). 
Description.-Shell medium or large for the genus, trigonally cuneiform and Anomalodiscus-like in outline, much longer than high, moderately inflated; test fairly thick; umbo prominent, slightly incurved, prosogyrous, placed at about one-third of shell-length from the anterior end; antero-dorsal margin slightly concave in front of umbo, smoothly sloping down into the anterior margin; postero-dorsal margin gently convex, much longer than the anterodorsal; posterior margin poorly delimited from the postero-dorsal and ventral ones; ventral margin commonly slightly concave in the posterior part but gently arcuate in the anterior part; a blunt carina runs from the umbonal region to the postero-ventral corner, defining a postero-dorsal slope; lunule unusually wide but comparatively shallow, nearly smooth, circumscribed by a shallow furrow; escutcheon broad, nearly smooth, about $3 \mathrm{~mm}$. in the maximum width, delimited by an angular ridge; surface ornamented with more than 60 radial riblets in addition to many irregular erect concentric lamellae; radials much weakened on the concentric ribs and ventral peripheral area, but apparently continuous; both elements of ornamentation somewhat effaced on the posterodorsal slope behind the carina; ligament external; hinge of Eomiodon-type as formulated: $\frac{\text { AIII AI } 3 \mathrm{a} 3 \mathrm{~b} 5 \mathrm{~b} \text { PI }}{\text { AII } 24 \mathrm{~b} \text { PII }}$ cardinal teeth stout, never bifid, radiating from the umbo; 2 stout, slightly prosocline, placed just below the umbo; $3 \mathrm{a}$ acline, represented by the terminal thickening of AIII; $3 \mathrm{~b}$ stout, triangular, prosocline; $4 \mathrm{~b}$ thinner than $3 \mathrm{~b}$, elongated, very prosocline; $5 \mathrm{~b}$ very small, clearly demarcated from the nymph; lateral teeth elongated along the anteroand postero-dorsal margins, apparently not cross-striated; nymph comparatively narrow; adductor scars weakly impressed, comparatively small, placed near the both ends of the lateral teeth; pallial line not sinuated but somewhat abruptly bent upwards below the posterior adductor scar; pedal scar not clearly impressed; umbonal cavity moderate in depth.

Measurements in $\mathrm{mm}$.

\section{Specimen}

Holotype (GK.H6502) right ex. mould

Paratype (GK.H6503) right in. mould

Paratype (GK.H6504) right in. mould

Paratype (GK.H6505) right in. mould

Paratype (GK.H6506) left ex. mould

Paratype (GK.H6507) left in. mould

Paratype (GK.H6673) right ex. mould

Paratype (GK.H6674) right in mould

Paratype (GK.H6675) left in. mould

Paratype (GK.H6676) left ex. mould

Paratype (GK.H6677) right in. mould

$\begin{array}{cccl}\text { Length } & \text { Height } & \text { Thickness } & \text { L/H } \\ 21.5 & 17.0 & 4.0 & 1.26 \\ 24.0 & 19.0 & 5.0 & 1.26 \\ 20.5 & 17.0 & 4.5 & 1.21 \\ 20.5+ & 17.5 & 4.5 & 1.17+ \\ 22.0 & 16.0+ & 5.0 & 1.38- \\ 19.0 & 15.0 & 4.0 & 1.27 \\ 24.5 & 19.5 & 6.0 & 1.26 \\ 21.0 & 17.0 & 4.0 & 1.24 \\ 20.0 & 17.0 & 4.0 & 1.18 \\ 20.5+ & 18.0 & ? & 1.14+ \\ 18.0 & 14.5 & 3.5 & 1.24\end{array}$

Observations and comparisons.-The surface and internal characters are clearly exhibited in the internal and external moulds of two valves above measured. They are variable to a certain extent in the ratio of length/height, concentric sculpture and degree of the concavity of the ventral margin, but 
the Eomiodon-like dentition, radial ornamentation and clearness of lunule and escutcheon seem quite invariable.

Matsumoto and Kanmera (1952) and Matsumoto (1954) referred the present species to Cyrena radiatostriata YABE and NAGAO, in YABE, NAGAO and SHImizu (1926), from the Lower Cretaceous of the Sanchu area. The present species is in fact, intimately related to $C$. radiatostriata in view of the essentially similar external and internal characters, but differs from that species in the larger dimensions, larger ratio of length/height, weaker shellconvexity, only weakly curved anterior lateral teeth, more centrally placed umbo and not so clearly interrupted radial riblets.

Cyrena paradoxa Steinmann, 1881, from the Albian of Peru, has similar radial riblets, which are crossed also by prominent concentric lamellae, and it is probable that the Peruvian species is actually congeneric with the present species. However, the detailed internal structure of $C$. paradoxa is unknown, and the concentric ribs seem finer than in the present species. Moreover, the lunule is apparently not so clearly discriminated in that species.

Occurrence.-Upper Miyakoan (Albian). Dark grey sandy shale of the Yatsushiro formation at loc. Hy. 1017 and $\mathrm{Km} .3035$, west of Mt. Jogusan, Miyaji, Yatsushiro City, Kumamoto Prefecture. Comparable specimens occur, though rarely, in the basal part of the Hinagu formation at loc. $\mathrm{Km} . \mathrm{1639b}$, northwest of Harameki (on the left bank of the River Kuma), the same city (MATsumoto and FuJII coll.).

\section{Costocyrena radiatostriata (YABE and NAGAO)}

Plate 19, Figures 1-7

1926. Cyrena radiatostriata YABE and NAGAO, in YABE, NAGAO and SHIMIzU, Sci. Rep. Toholu Imp. Univ., Ser. 2, Vol. 9, Pt. 3, p. 51, pl. 12, figs. $29-35$, pl. 13, fig. 45 .

1926. Cyrena radiatostriata, YABE and NAGA0, Chikyu, Vol. 5, No. 9, pp. 4, 6, listed.

non 1952. Polymesoda (Costocyrena) radiatostriata, MATsumoto and KANMERA, Guide book of the geol. excursions: The lower valley of the Kuma; pp. 44,50 , listed. [=Costocyrena matsumoto $i$ sp. nov.]

1954. Polymesoda (Costocyrena) radiatostriata, Matsumoto, Cretaceous System, Japan. Islands, p. 63 (non pp. 112, 115), listed.

1955. "Cyrena" radiostriatus, CASEY, Jour. Washington Acad. Sci., Vol. 45, No. 12 , p. 369 [sic]

Material.-A left valve (IGPS reg. no. 35523) illustrated by YABE, NAGAO and SHimizu (1926, pl. 12, fig. 31) is here designated as the lectotype. It was collected from the "Shiroi formation" (now called Sebayashi formation) at Hachimanzawa, south of Kagahara, Nakazato village, Tano County, Gumma Prefecture. Other syntypes are also examples of this species. Six more specimens (GK. H 6496-GK. H 6501) from the type area (ICHIKAWA and HAYAMI coll.) are also concerned with the description below.

Description.-Shell small- or medium-sized for the genus, very inequilateral, 
trigonally ơvate, longer than high, strongly inflated; test fairly thick; umbo prominent, incurved, prosogyrous, placed at about one-fourth of shell-length from the anterior extremity; antero-dorsal margin slightly concave in front of umbo, comparatively short; postero-dorsal margin much longer, gently convex or nearly straight; posterior margin short, obscurely delimited from the postero-dorsal by an obtuse angle, turning angularly to the ventral margin; ventral margin nearly straight in the posterior part but gently areuate in the anterior part, passing gradually into the anterior; a rounded carina extends from the umbonal area to the postero-ventral corner, defining a steep posterodorsal slope; lunule shallow but wide, occupying the greater part of the anterodorsal margin, nearly smooth; escutcheon broad, nearly smooth, bounded by an angular ridge; ligament external, not much elongated; surface ornamented with more thàn 70 radial riblets which are interrupted with more or less regular and erect concentric lamellae; radials and concentrics much weakened on the postero-dorsal part and almost indiscernible near the peripheral area; hinge similar to that of Costocyrena matsumotoi sp. nov., although the posterior eardinal tooth $5 \mathrm{~b}$ is slightly smaller and the anterior lateral teeth are more strongly curved or geniculated in the present species; nymph comparatively narrow; adductor scars weakly impressed; umbonal cavity moderate in depth.

Measurements in $\mathrm{mm}$.

Specimen

Right in. mould (GK.H6496)

Right in. mould (GK.H6497)

Left in. mould (GK.H6498)

Right in. mould (GK.H6499)

Left valve (GK.H6500)

$\begin{array}{cccc}\text { Length } & \text { Height } & \text { Thickness } & \text { L/H } \\ 17.5 & 15.5 & 5.0 & 1.13 \\ 16.0 & 13.5 & 4.5 & 1.19 \\ 16.5 & 14.5 & 4.5 & 1.14 \\ 14.5 & 12.0 & 3.5 & 1.21 \\ 16.5 & 14.0 & 5.0 & 1.18\end{array}$

Observations and comparisoñs.-Six specimens and several frägments identitical with "Cyrena" radiatostriata YABE and NAGAO were collected from the type locality. However, all the syntypes and newly collected specimens are not well preserved, and the external and internal characters are known on a few artificial moulds. Although the material is mostly secondarily deformed, the present species is charâcterized by the relatively tall outline, interrupted radial riblets and strongly curved anterior lateral teeth. The thickness of the cardinal tooth $3 \mathrm{~b}$ is somewhat variable and the prominence of the posterior carina is not constant.

It is obviously congeneric with and closely related to Costocyrena matsumotoi in view of the essentially similar ornamentation and dentition. As noted before (p. 136), however, they are specifically distinguishable from each other.

Occurrence.-Aritan and Miyakoan (upper Neocomian to Aptian or Albian). Black shale of the Sebayashi formation at loc. Hy. 4005, Hachimanzawa, south of Kagahara, Nakazato village, Tano County, Gumma Prefecture. The locality was formerly included in the "Shiroi formation" which has been accustomally correlated to the lower Neocomian Kochian (Ryoseki) series, but, as clarified 
by ARAr et al: (1958), the horizon must be as high as Miyakoan (AptianAlbian). YABE, NAGAO and SHIMIzU reported the present species also from the "Shiroi formation" at Shiroi and Bomekizawa of the same area, but the stratigraphic position of those fosisil beds should be further carefully studied. Several poorly preserved specimens, which are probably identical with the present species, occurred from the Nagaiso formation of the Ofunato group at loc. Hy. 0051, east of Kadonohama, Massaki of Ofunato City, Iwate Prefecture.

\section{Costocyrena sp. aff. C. radiatostriata (YABE and NAGAO) \\ Plate 18, Figüres 13-15}

Five specimens (GK. H 6681-GK. H 6685) and a few fragmentary moulds are available for the study. Because of the somewhat coarse-grained matrix, the detailed characters of the hinge and surface are not preserved, but the presence of characteristic radial and concentric ornaments and Eomiodonlike dentition is recognized in some specimens. In the anterior position of umbo, regular concentric ribs and the ratio of length/height, the present species agreès better with Costocyrena radiatostriata (YABE and NAGAO) than with C. matsumotoi sp. nov. However, the anterior lateral teeth äre not so strongly curved as those of the former species, and the nymph seems to be narrower than in the two species. The present species is certainly referable to Costocyrena, and probably belong to a new species. The illustrated specimens: left external mould (GK. H 6681) $16.0 \mathrm{~mm}$. long, $14.5 \mathrm{~mm}$. high, $3.5 \mathrm{~mm}$. thick; right internal mould (GK. H 6682) $19.0 \mathrm{~mm}$. long, $16.5 \mathrm{~mm}$. high, $4.0 \mathrm{~mm}$. thick.

Occurrence-Miyakoan (Aptian or Albian). Weathered sandstone of the basal part of the Izeki formation at loc. Ys. 1021, Yoshikawa of Ishigaki, Kanaya town, Arita County; Wakayama Prefecture (Matsumoto coll.).

Superfamily Arcticacea

Family Arcticidae

Genus Isocyprina RoEDER, 1882

Type-species.-Caraium cyreniforme Buvignier, Oxfordian, Europe (monotypy).

\section{Isocyprina aliquantula (AMANo)}

Plate 19, Figures 8-9

1957. Cyprina aliquantula Amano, Kumamoto Jour. Sci., Ser. B, Sec. 1, Vol. 2, No. 2, p. 95 , pl. 2, figs. $13-18$.

Material.-The holotype is an internal mould of right valve (GT.KML0026) illustrated by Amano (1957, pl. 2, fig. 14). It was collected from the Hagino formation at Hagino, Mirafu village, Kami County, Kochi Prefecture. Other specimens described by Amano (1957, pl. 2, figs. 13, 15-18) are also 
good examples of this species. Three more specimens (GK. H 6597-GK. H 6599) from the type area (OGAWA coll.) are also concerned with the description below.

Description.-Shell small for the genus, inequilateral, subovate, not carinated, much longer than high, strongly inflated; test moderate in thickness; antero-dorsal margin slightly concave in front of the umbo; postero-dorsal margin long, slightly convex, passing gradually into the posterior margin; ventral margin gently arcuate; umbo not very salient, prosogyrous, placed at about two-fifths of length from the anterior end; lunule not impressed, but the corresponding area is circumscribed by a weak line; escutcheon narrow, clearly delimited; surface smooth except for weak growth-lines; hinge of cyprinoid type, as formulated: $\frac{\text { (AIII) AI } 3 \mathrm{a}(1) 3 \mathrm{~b} \text { PI }}{\text { AII } 2 \mathrm{a} 2 \mathrm{~b} 4 \mathrm{~b} \text { PII }}$; cardinal tooth 1 embryonal, prosocline, represented by the terminal thickening of $\mathrm{AI}$; $2 \mathrm{a}$ and $2 \mathrm{~b}$ continuous, narrow, forming an obtuse chevron below the beak; 3a narrow, very small, parallel to the antero-dorsal margin; $3 \mathrm{~b}$ and $4 \mathrm{~b}$ long, very prosocline or almost parallel to the post-umbonal margin; nymph comparatively narrow; AI and AII very weak; AIII not clearly distinguishable from the valve margin; PI and PII comparatively short but very sharp, parallel to postero-dorsal margin; ventral margin smooth internally; musculature not clearly impressed.

Measurements in $\mathrm{mm}$.

Specimen

Right in. mould (GK.H6597)

Right ex. mould (GK.H6598)

Right ex. mould (GK.H6599)

$\begin{array}{cccc}\text { Length } & \text { Height } & \text { Thickness } & \text { L/H } \\ 18.0 & 14.0 & 6.0 & 1.29 \\ 14.0 & 11.0 & 4.5 & 1.27 \\ 12.5 & 10.0 & 4.0 & 1.25\end{array}$

Observations and comparisons.-AMANo described several specimens from the Hagino formation under the name of Cyprina aliquantula, with which the present specimens are certainly identical. As pointed by him, there are two different forms in the original specimens. One is represented by transversely elongated specimens $(\mathrm{L} / \mathrm{H}$ larger than 1.20$)$, and the other by shorter specimens ( $\mathrm{L} / \mathrm{H}$ approximately 1.10). It is possible that the two forms belong to different species, but the elongated specimens including the present ones are anyhow typical for $C$. aliquantula.

Although the non-carinated and subovate outline recall some genera of the Veneridae, the cyprinoid dentition revealed in one of the present specimens (GK. H 6597) and the holotype indicates that the present species belongs to Isocyprina of the Arcticidae. Isocyprina flourished extensively in the Middle and Upper Jurassic, but, as noted by CASEY (1952), some species from the Lower Cretaceous of Europe are referable to the genus.

Of a number of species of Isocyprina, the present species is especially similar to Isocyprina sedgwicki (WALKER, 1866) from the Lower Greensand of England (KeEPING, 1883; WoODS, 1907; CASEY, 1961) in the outline and dentition. However, the size is much smaller and the growth-lines are much weaker in the present species than in I. sedgwicki.

Occurrence.-Lower Miyakoan (Aptian). Grey fine sandstone of the Hagino 
formation at loc. Hy. 6011, Hagino, Mirafu village, Kami County, Kochi Prefecture. Similar specimens were procured from the Hoji formation at loc. Hy. 5019, near the coal mine of Katsuura, south of Fujikawa, Kamikatsu town, Katsuura County, Tokushima Prefecture.

Genus Veniella SToLICzKA, 1871

Type-species.-Venilia conradi MoRToN, 1833, Upper Cretaceous, U.S.A. (original designation).

\section{Veniella sp. aff. V. japonica NAGAO}

Plate 19, Figure 10

1954. Veniella (?) cf. japonica NAGAo, Matsumoto, Cretaceous System, Japan. Islands, p. 115, listed.

The present species is represented by right and left valves, which adhere to a slab and probably belong to the same individual.

Shell medium-sized, inequilateral, trapeziform, slightly higher than long, strongly inflated (right internal mould, GK. H 6595, $42.0 \mathrm{~mm}$. long, $47.0 \mathrm{~mm}$. high, $18.5 \mathrm{~mm}$. thick; left internal mould, GK. H 6596, 38.5+mm. long, 43.5+mm. high, $17.5 \mathrm{~mm}$. thick) ; test probably thick; antero-dorsal margin nearly straight, but the lunular region deeply concave; postero-dorsal margin straight or a little convex, comparatively short, turned to the well delimited siphonal margin with an obtuse angle; umbo highly protruded, prosogyrous, placed at about two-fifths of length from the anterior end; a rounded carina extending from the umbonal region to the postero-ventral angle, clearly defining a slightly concave posterior area; escutcheon probably delimited; surface ornamentation unknown in detail, not impressed on the internal surface; dentition unknown; umbonal cavity deep.

The outline of these specimens is similar to that of Veniella (?) japonica NAGAO, 1930, from the Gosyonoura group of west Kyushu. NAGAo's and the present species may not be typical representatives of Veniella, but the generic name is accepted with a query until their hinge structure is known. The present specimens are probably specifically different from NAGAo's, because the dimensions are much smaller than in the type specimen of $V$. (?) japonica.

Occurrence.-Upper Miyakoan (Albian). Grey medium sandstone of the Yatsushiro formation at loc. Km.3151, northwest of Mt. Happosan, Miyaji, Yatsushiro City, Kumamoto Prefecture (KANMERA coll.).

\section{? Superfamily Veneracea}

? Family Veneridae

Genus Ptychomya Agassiz, 1845

(=Radioconcha CONRAD, 1869)

Type-species.-Ptychomya plana AGASsIZ, 1845, Lower Cretaceous, western 
Europe and? South America (=Crassatella robinatdina D’ORBIGNY, 1844) (monotypy).

Remartes-Ptychomya is a peculiar Upper Jurassic-Upper Cretaceous pelecypod genus, well characterized by the strikingly divaricated ornament on the anterior surface and the strong sub-radial ribs on the posterior surface.

Since D'ORBIGNY (1844) regarded the type-species of this genus as a -member of Crassatella, Ptychomya had long been placed in the Crassatellidae (Pictet and CAMPICHe, 1866; Stoliczka, 1871). In fact, the subinternal ligament and strongly impressed anterior adductor scar may remind one of the Astartacea. Of numerous genera of the Astartacea, such a divaricated ornament is known in Midiraon Vokes, 1946, of the Scambulinae from the Aptian of Lebanon and in Ensio Cox, 1962, of the Astartidae from the Middle-Upper Jurassic of western Europe and Borneo.

DAMES (1873), however, pointed out the morphological similarity between Ptychomya and Circe (Crista) of the Veneridae, and since then, the reference of Ptychomya to this family has been accepted by many palaeontologists including Fischer (1887), Woods (1907), Gillet (1924a), WEAVER (1931), ChavaN (1952a) and Cox (1954a). Similarly divaricated ribs are commonly known in Circe, Gafrarium and some other genera of the Circinae.

The dentition of Ptychomya appears to be composed of three cardinal teeth in each valve, although the left posterior cardinal tooth is not clearly separated from the nymph. GILleT (1924a) and CHAVAN (1952a) interpreted the hinge structure of Ptychomya robinaldina (D'ORBIGNY) as follows: $\frac{3 \mathrm{a} 13 \mathrm{~b}}{2 \mathrm{a} 2 \mathrm{~b} 4 \mathrm{~b}}$. If the denomination is correct, the hinge structure of Ptychomya is of typical cyrenoid type, and apparently not much apart from that of Gafrarium and Circe. The lateral teeth are likewise somewhat obsolete in many Recent species of the Veneridae, especially in the Circinae. The pallial line is turned more or less abruptly upwards below the posterior adductor in Ptychomya, and not sinuate as in normal species of the Veneridae. In the Circinae, however, the pallial sinus is very shallow or almost absent as in Ptychomya.

Nevertheless, I wonder whether Ptychomya should be dealt with as a true representative of the Veneridae, in view of its peculiar morphology and early stratigraphic occurrence. The occurrence of Ptychomya so far known is mostly restricted to the Lower Cretaceous, but there are a few Upper Jurassic species. Ptychomya stantoni Cragin, 1905, from the Malone formation of Texas, possesses characteristic surface sculpture of Ptychomya. Although KITCHIN (1926) regarded the age of the Malone fauna to be Cretaceous, the coexistent ammonites indicate a Kimmeridgian age for the fossil beds in question (ALBRITTON, 1937; ARKELL, 1956). In the Upper Jurassic, on the contrary, no other representative of the Veneridae is known. Eocallista DouvilLé, 1921, from the Middle-Upper Jurassic, which was once regarded as primitive venerids, is regarded as a member of the Arcticidae, as pointed out by Cox (1947). The Verneidae, as interpreted by CASEY (1952), must have been derived from the Arcticidae 
mainly in the Lower Cretaceous. Although it is not impossible that the Veneridae were evolved polygenetically from several genera of the Arcticidae, the anterior and posterior lateral teeth are well developed in every species of the advanced Areticidae and primitive Veneridae of this period. In the undeveloped lateral teeth and apparently primitive musele system, Ptychomya is quite different from the Veneridae of the Lower Cretaceous. The genus may have constituted a distinct lineage of evolution, whatever alliance to the Circinae it may bear.

If the obscure "posterior cardinal tooth" of the left valve would be proved only a marginal elevation of the nymph, another interpretation might be possible for the hinge structure of Ptychomya, as follows: $\frac{3 a 3 b 5 b}{24 b}$. This formula might suggest an astartoid hinge, because the cardinal tooth $5 \mathrm{~b}$ is characteristically developed in the Astartidae and their descendent families. In the present paper I follow many palaeontologists in referring Ptychomya to the Veneridae, but it is still possible that the genus is phylogenetically more close to the Astartacea than to the Veneracea. The peculiar morphology of Ptychomya might require the establishment of a new suprageneric category.

\section{Ptychomya densicostata NAGAO}

Plate 21, Figures 1-4

1934. Ptychomya densicostata NAGAO, Jour. Fac. Sci., Hokkaido Imp. Univ., Ser. 4, Vol. 2, No. 3, p. 224, pl. 28, fig. 4.

1952. Ptychomya kiiensis Matsumoto, in Matsumoto and Kanmera, Guide book of the geol. excursions: The lower valley of the Kuma, p. 49, nom. nud.

1954. Ptychomya kiiensis Matsumoto, Cretaceous System, Japan. Island, pp. 76,115 , nom. nud.

Material.-In the original description of this species NAGAo noted, "Two imperfect valves were obtained". His illustrated specimen (NAGAO, 1934, pl. 28, fig. 4) is here designated as the lectotype. It is now missing, although it should belong to the collection of the Tohoku University or the Hokkaido University. The type locality was said to be the "Orbitolina sandstone" of the Miyako group at the northern coast of Raga, Tanohata village, Shimohei County, Iwate Prefecture. The following description is based on five specimens, two (GK. H 6512, GK. H 6697) from the Yuasa area (Matsumoto et al. coll.), one (GK. H 6513) from the Ofunato area (OBATA, TokuYama and HaYami coll.), one (GK. H 6698) from the Yatsushiro area (KANMERA coll.) and one (GK. H 6699) from the Sanchu area (ICHIKAWA and HAYAMI coll.).

Description.-Shell medium-sized for the genus, subelliptical, about 1.6 times longer than high, not strongly inflated; test thick; antero-dorsal margin short, more or less concave in front of the umbo; postero-dorsal margin nearly horizontal, occupying about a half shell-length, forming an obtuse angle with the obliquely truncated siphonal margin; ventral margin subparallel to the 
postero-dorsal, meeting siphonal margin at the postero-ventral extremity with an angle of approximately 70 degrees; umbo placed at about one-fifth of shelllength from the anterior extremity, not salient above the dorsal margin; a blunt carina running diagonally from the umbo to the postero-ventral corner, delimiting obscurely a slightly concave postero-dorsal area; lunule probably very narrow, compressed; ornamentation consisting of subradial and remarkably divaricated ribs; anterior part, which occupies about one-sixth of whole surface, marked with numerous upwardly concave fine ribs; middle part of the surface ornamented with about 40 subradial ribs which become stronger and more widely spaced towards the posterior carina; about 12 of them on the posteromedian part starting from the umbo; postero-dorsal slope behind the carina provided with about a dozen of stout radial ribs, of which two or three near the carina are converged and disappeared towards the postero-ventral corner; postero-dorsal peripheral area corrugated with about ten oblique nodose riblets; valve margin except for the periphery of the nymph marked with numerous internal crenulations which are much finer than the traces of the radial ribs; hinge and ligament structure of typical Ptychomya; cardinal teeth thick, rounded at the tops; lateral teeth undeveloped; dentition as formulated: $\frac{3 \mathrm{a} 13 \mathrm{~b}}{2 \mathrm{a} 2 \mathrm{~b}(4 \mathrm{~b})} *$ $3 \mathrm{a}$ conical and small; $2 \mathrm{a}$ slightly longer than $3 \mathrm{a}$, nearly vertical; 1 and $2 \mathrm{~b}$ stout, prosocline; $3 \mathrm{~b}$ broad, very prosocline; $4 \mathrm{~b}$ not clearly demarcated from the nymph; posterior part of the nymph excavated hemicylindrically by a large ligament pit; anterior adductor scar strongly impressed, placed just in front of the hinge plate; pedal scar clearly impressed behind it; posterior adductor scar larger than the anterior one, but weakly impressed; pallial sinus absent, although the pallial line is abruptly bent upwards below the posterior adductor; umbonal cavity very shallow.

Measurements in $\mathrm{mm}$.

Specimen

Left in. mould (GK.H6512)

Both valves (GK.H6513)

Left in. mould (GK.H6697)

Right in. mould (GK.H6699)

$\begin{array}{cccc}\text { Length } & \text { Height } & \text { Thickness } & \text { L/H } \\ 67.5 & 42.5 & 9.0 & 1.59 \\ 56.0 & 40.0 & 12.5 & 1.40 \\ 62.0 & 37.0 & ? & 1.68 \\ 56.0+ & 41.5+ & ? & ?\end{array}$

Observations and comparisons.-The surface sculpture is best shown in two of the present specimens (GK. H 6512, GK. H 6513), which were collected respectively from the Yuasa and Ofunato areas. The Yuasa specimen, composed of well preserved internal and external moulds, has more distinct carina and slightly more densely spaced radial ribs on the posterior area than the lectotype of $P$. densicostata NAGA0, 1934, from the Miyako area. The Ofunato specimen shows noticeable zigzag arrangement of anterior riblets, and its outline is somewhat shorter and more quadrate than in the lectotype and the Yuasa specimen. As mentioned by WeAver (1931) on Ptychomya koeneni BeHrendsen,

\footnotetext{
* Another interpretation is possible for the notation (See p.141).
} 
1891, including several "varieties", the intraspecific variation of ornamentation may be fairly wide in each species of Ptychomya. The Arita and Ofunato specimens might eventually be separated subspecifically from typical $P$. densicostata, but the material of each area is represented only by one or a few specimens, and the criteria are still insufficient.

MAtsumoto and Kanmera (1952) used the name Ptychomya kiiensis (nom. $n u d$.) on a specimen from the Yatsushiro formation (GK. H 6698), and MATsUмото (1954) suggested in his lists that the Arita specimen (GK. H 6512) is conspecific with the Yatsushiro specimen but different from the Miyako specimen. An examination was made also on the Yatsushiro specimen, but no essential diagnostic character for a specific distinction was found. In this paper, therefore, all the specimens are referred to one species, Ptychomya densicostata.

I agree with NAGAO (1934, p. 225) and DIETRICH (1936, p. 400) in considering that the present species closely resembles Ptychomya robinaldina (D'ORBIGNY, 1844), from the upper Neocomian and Aptian of Europe (PICTET and RENEVIER, 1858) and South America (DIETRICH, 1939). The reliable description and illustration of this species were given by Woons (1907, p. 179, pl. 27, figs. 24-26) and Chavan (1952). Every specimen of P. densicostata at my disposal, however, has a shorter postero-dorsal margin and more delicate posterior radial ribs near the carina. The ratio of length/height appears slightly smaller than in European specimens. In the relatively short shell and zigzag arrangement of the anterior riblets, the Ofunato specimen is more similar to Ptychomya neocomiensis (DE LoRIOL, 1861) than to P. robinaldina. WooDs (1907) suggested, however, that the two are actually conspecific. The relationship among the present and the two European species should be further examined on the basis of their variation and geographic distribution.

Ptychomya kitchini LANGE, 1914, from the Tendaguru formation of East Africa, is also comparable with the present species in many characters, but the radial ribs of the African species are broader and more flattened at the tops.

Occurrence.-Aritan and Miyakoan (upper Neocomian to Albian). Dark grey sandy shale of the Arita formation at loc. Ys. 103, west of Kumai, Yuasa town, Arita County, Wakayama Prefecture. Black shale of the Nagaiso member of the Ofunato group at loc. Hy. 0053, the opposite side of "Kinchakuiwa", north of Goishi, Massaki, Ofunato City, Iwate Prefecture. Grey sandy shale of the Ishido formation at loc. Hy. 4001, Ichinose-bashi, south of Kagahara, Nakazato village, Tano County, Gumma Prefecture. Fine sandstone of the Yatsushiro formation at loc. Km. 1843, north of Shimofukami, Sakamoto town, Yatsushiro County, Kumamoto Prefecture. NAGA0 (1934) reported originally this species from the "Orbitolina sandstone" of the Miyako group at Raga, "Tanohata village, Shimohei County, Iwate Prefecture. No additional specimen has been collected from the type area. 


\section{Superfamily Veneracea \\ Family Veneridae}

Remarks.-Cenozoic and Recent genera of the Veneridae are generally classified into several subfamilies (FrIZZELL, 1936; KEEN, 1951, 1958, etc.). Cretaceous species of this family including the species described in the present paper have usually less degenerated anterior and posterior lateral teeth than the Cenozoic and Recent species. The character indicate that this family were originated from the advanced Arcticidae. As pointed out by CASEY (1952), NICOL (1958) and ICHIKAWA and MAEDA (1963), hitherto proposed systematics of the Veneridae are at least in part not applicable, when the Cretaceous species are taken into consideration.

\section{Genus Agapella VoKes, 1946}

Type-species.-Agapella rotunda VoKEs, 1946, Aptian, Lebanon (original designation).

\section{Agapella (?) koikorobensis sp. nov.}

Plate 20, Figure 14

Material.-The holotype is a left valve (GK. H 6495) collected from the Tanohata formation at loc. Hn. 0803, Koikorobe, Tanohata village, Shimohei County, Iwate Prefecture (HAYAMI coll.).

Description.-Shell medium-sized, suborbicular, inequilateral, moderately inflated, slightly longer than high (Holotype, GK. H 6495, left valve, $31.5 \mathrm{~mm}$. long, $29.0 \mathrm{~mm}$. high, $8.0 \mathrm{~mm}$. thick); test comparatively thin; antero-dorsal margin short, a little concave in front of the umbo; postero-dorsal margin gently convex, passing gradually into the siphonal margin; ventral margin smoothly arcuate without any angulation; umbo prosogyrous, scarcely rising above the dorsal margin, placed at about one-third of length from the anterior end; lunule excavated, circumeribed by an angular sulcus; escutcheon narrow, clearly delimited by an angular ridge; a blunt carina extending from the umbo to the postero-ventral area, defining obscurely a broad posterior slope which occupies approximately one-third of the surface; surface smooth except for weak concentric lines of growth; ventral margin smooth internally; hinge and musculature unknown.

Observations and comparisons.--Only a left valve is available for the study. Its hinge is not exposed, but the exterior and the interior of the ventral peripheral part are well exhibited. The weakly carinated shell and the prosogyrous. umbo may recall those of the Arcticidae, such as Venilicardia SToLIczKA, 1871 (type-species: Cyprina bifida ZITTEL), and Epicyprina CASEY, 1952 (typespecies: Venus angulata SowERBY). The escutcheon of the present specimen is, however, more sharply delimited, and the umbonal area is not so broadly inflated as in those genera. 
Of numerous species of Cretaceous venerids and arcticids, the present specimen is most closely allied to Agapella ratunda VoKES, 1946, from the Aptian of Lebanon, in the external characters. Agapella was proposed as a genus of the Veneridae. Although its reference to the family is not very clear owing to the ignorance of the musculature of the type-species, VoKes (1946, pl. 9, figs. 4, 5) showed the dentition of $A$. rotunda, which is, I think, of an early cyrenoid type instead of an advanced cyprinoid type.

The present species is, however, distinguishable from $A$. rotunda in the somewhat weaker shell-convexity and the slightly broader posterior slope. It is provisionally referred to Agapella, until its hinge becomes clear.

Occurrence.-Lower Miyakoan (Aptian). Conglomeratic sandstone of the Tanohata formation at loc. Hn. 0803, Koikorobe, Tanohata village, Shimohei County, Iwate Prefecture.

\section{Genus Nagaoella nov.}

Type-species.-Dosiniopsis corrugata NAGAO, 1934, Aptian-Albian, Japan.

Diagnosis.-Shell small for the family, subelliptical, longer than high, strongly inflated; umbo prosogyrous, placed anteriorly; lunule superficial, large but shallow; escutcheon clearly delimited; surface shiny, smooth except for subinternal radial threads and growth-lines; hinge plate comparatively narrow, provided with three cardinal teeth and a pair of lateral teeth of early cyrenoid type in each valve, as formulated: $\frac{\text { (AIII) AI } 3 \mathrm{a} 13 \mathrm{~b} \text { PI }}{\text { AII } 2 \mathrm{a} 2 \mathrm{~b} 4 \mathrm{~b} \text { PII }} ; 3 \mathrm{a}$ and $2 \mathrm{a}$ small, thin; $2 \mathrm{~b}$ and $3 \mathrm{~b}$ thick; $3 \mathrm{~b}$ not much curved downwards, distinctly bifid; lateral teeth somewhat elongated along valve margin but comparatively weak; pallial line triangularly sinuate; adductor impressions comparatively weak and small; valve margin finely crenulated internally in accordance with the subinternal radial threads; umbonal cavity moderate in depth.

Remarks.-NAGAo described a venerid from the Aptian-Albian Miyako group under the name of Dosiniopsis cormugata. Though the detailed characters of the type-species of Dosiniopsis ConRAD, 1864, i.e. D. meekii ConRaD, 1864, from the Eocene near Washington D.C. (designated by TATE, 1868) are not well known at present, good illustrations of some allied species of the genus from the Eocene of the Atlantic Coastal region were given by CLARK (1896, 1901). As mentioned by Stewart (1930, p. 251), Dosiniopsis subrotunda (SoWERBY, 1836) from the Upper Greensand of England (WooDs, 1908) appears to be an early representative of this genus. So far as I am aware, however, there is no Aptian or earlier species which has been referred or is referable to Dosiniopsis.

The hinge structure of the Miyako species, which was well exhibited in NAGA0's figure (1934, pl.24, figs. 2-5) and is also observable in the present material, is somewhat similar to that of $D$. subrotunda in the disposition of the cardinal and lateral teeth, but the cardinals $3 \mathrm{a}, 2 \mathrm{a}$ and 1 are much shorter. Moreover, subinternal radial threads and marginal crenulations are absent in 
all the hitherto known species of Dosiniopsis. As maintained by NAGAO (1934) and ICHIKAWA and MAEDA (1963), the presence of marginal crenulations seems to be an important criterion for the classification of the Veneridae.

CASEY (1952) carried out an outstanding study on the Cretaceous species of the Arcticidae and Veneridae, proposing three new genera and three new subgenera in the latter family on the basis of some Lower Cretaceous species in the following way:

Genus Rasatrix CASEY, 1952 (type-species: Rasatrix dolobra CASEY; Aptian)

Subgenus Rasatrix s. str.

Subgenus Vectorbis CASEY, 1952 (type-species: Venus vectensis FORBES, Albian) Subgenus Dosiniopsella CASEY, 1952 (type-species: Rasatrix (Dosiniopsella) cantiana CASEY, Albian)

Genus Pseudaphrodina CASEY, 1952 (type-species: Venus recordeana D'ORBIGNY, Lower Cretaceous)

Genus Paraesa CASEY, 1952 (type-species: Venus faba Sowerby, Albian)

Genus Calva Popenoe, 1937 (type-species: Calva rigina Popenoe, Turonian)

Subgenus Calva s. str.

Subgenus Chimela CASEY, 1952 (type-species: Venus caperata SowERBY, Albian)

In addition, the following taxa are commonly admitted as valid genera of the Cretaceous Veneridae: Legumen CoNRAD, 1858 (type-species: L. ellipticum CoNRAD), Cyprimeria ConRAD, 1864 (type-species: C. excavata MorToN), Aphrodina ConRAD, 1869 (type-species: Meretrix tippana Conrad), Tenea CoNRAD, 1870 (type-species: Mysia parilis CoNRAD), Cyclorisma DALL, 1903 (type-species: Cyprimeria carolinensis CONRAD), Callistina JuKES-Browne, 1908 (type-species: Venus planus SowerBY), Tikia MARWICK, 1923 (type-species: Callistina thomsoni WooDs), Trigonocallista RENNIE, 1930 (type-species: Meretrix umzabiensis Woods), Agapella VoKes, 1946 (type-species: Agapella rotunda VoKEs), Mesocallista Cox, 1952 (type-species: Meretrix andersoni Woods), Larma STEPHENSoN, 1952 (type-species: Callistina (Larma) munda Stephenson), Anofia REYMENT, 1955 (type-species: A. aro ReYMent) and Izumia ICHIKAWA, 1963 (type-species: I. trapezoidalis ICHIKAWA and MAEDA).

The hinge structure of the type-species of Nagaoella is not much apart from that of Rasatrix illustrated by CASEY (1952, pp. 161, 164). In the outline the present species resembles some of Rasatrix (s. s., Vectorbis and Dosiniopsella) as well as Dosiniopsis and Calva. CASEY suggested that Upper Cretaceous Dosiniopsis and Calva were derived from Lower Cretaceous Dosiniopsella and Rasatrix. Nagaoella is, however; distinct from those genera and subgenera in having distinct subinternal radial threads and fine marginal crenulations. Other distinctive characters of the present genus from Rasatrix are the nearly acline or prosocline cardinal tooth 1 and not much curved cardinal teeth $3 \mathrm{~b}$ and $4 \mathrm{~b}$.

Aphrodina and Callistina, which were sometimes treated as synonyms but generically separated by STEPHENSON (1952), have similar large superficioll lunule, but radial threads and marginal crenulations are absent in their type species. The shell is much larger and the pallial line is less angularly sinuater? 
than in the present type-species. A number of European Cretaceous species, which had been assigned to Cyprimeria or Cyclorisma by Woons (1908) and others, were included in Rasatrix by CASEY $(1952,1961)$, because of the difference of hinge and other essential characters from those of the American species. The detailed characters of Cyprimeria and Cyclorisma were clarified by STEPHENsoN (1923), and Nagaoella is certainly unrelated to them.

On the other hand, the present type species bears some affinities to Cyclina DeshaYes, 1850 (type-species: C. chinensis DeshaYes), which has been well known in the Cenozoic and Recent of eastern Asia. Although its Cretaceous forerunner is unknown except for some doubtful species such as Cyclina parva GARDNER, 1916, and Cyclina magna WADE, 1926, from the Upper Cretaceous of the Atlantic Coast of U.S.A., the present species is somewhat similar to this genus in the marginal crenulations, subinternal radial threads and bifid cardinal tooth 3b. Cyclinorbis MaKIYAMA, 1926 (type-species: Cyclina lunulata MAKIYAMA)*, appears to be characterized by the presence of a large superficial lunule and rather inconspicuous radial threads. It is, therefore, not impossible that the present genus is phylogenetically related to the Cyclininae. However, in Cyclina ( $s$. s. and Cyclinorbis) the anterior lateral teeth AI and AII are absent or scarcely developed, and there is a small but profound depression at the anterior end of ligament which is unknown in Nagaoella. Normal Cyclininae are much larger and taller than the present species. Moreover, the pallial sinus points more remarkably upwards in Cyclina and the hinge plate is more gradually narrowed towards both sides than in Nagaoella.

Thetironia SToLICzKa, 1871 (type-species: Thetis minor SoweRBY) has numerous radial riblets and comparatively thin test as in Nagaoella, but essentially different from it in the less prominent umbo, absence of well defined superficial lunule and more subequilateral outline. That genus has been usually included in the Veneridae, but the reference is doubtful, so far judged from the hinge structure of Thetironia laevigata (Woods, 1907, pl.26, fig. 10b).

Nagaoella is somewhat similar to the Pitarinae in the outline and shiny surface and to the Cyclininae in the subinternal radial markings. It is concluded, however, that the present genus disagrees with all the known genera of the Veneridae in the combination of internal and external characters.

So far as I am aware, there is no foreign species referable to the present genus with a certain confidence. Only "Callista" (Pseudamiantis) crenulata Matsumoto, 1938, from the Cenomanian and Turonian Gosyonoura group of west Kyushu (Amano, 1956) and the Mikasa group of Central Hokkaido, have similar subinternal riblets and distinct marginal crenulations and may be referable to the genus. The hinge of $C$. crenulata, as shown in one of the syntypes (Matsumoтo, 1938, pl. 1, fig. 5) and many topotype specimens, is not essentially different from that of the present type species. Although the outline of

* Cyclinorbis was originally proposed as a section of Cyclina. Subsequently MAKIYAMA (1936, p. 212) synonymized it with Cyclina, but KAMADA (1952) pointed out its distinctness and revived it as a subgenus of Cyclina. 
$C$. erenulata is more ovate and more Callista-likè, it may be better referred tỏ Nagaoella. Incidentally, the type-species of Pseudamiantis KUnoDA, 1933, i.e. "Méretrix" tauyensis YokоŸaMa, 1927, from the Pliocene Ommá formation of central Japan hăs, as recently restudied by IWASAKI (1963), smooth internal margin, much larger dimensions and more conspicuous lattice ornaments composed of external radial and concentric riblets. The hinge structure of $\ddot{P} s e u d a-$ miantis, which is characterized by the prosocline cardinals 3a and 2a, broadly triangular $2 \mathrm{~b}$ and non-bifid $3 \mathrm{~b}$, indicates that Nagaoella is not intimately related to that genus.

The present genüs is named after late Prof. Takiumi NAGAo of the Hokkaido (Imperial) University, who carried out an extensive study on the Cretaceous pelecypod faunas of Japan and suggested a possibility of a subgeneric distinction of the present type-species from typical Dosiniopsis.

\section{Nagáoella corrugata (NAGAO)}

Plate 19, Figures 12-15; Plate 20, Figures 1-12

1934. D̈osiniopsis corrugata NAGAO, Jour. Fàc. Sci., Hokkaido Imp. Univ., Ser. 4, Vol. 2, No. 3, p. 229, pl. 24, figs. 2-6, 9.

1962. "Dosiniopssis" corruǵata (gen. nov.), HAYAMI, Kaseki (Fossils̈), Nô. 4, p. 77, listed.

Material.-The holotype is a right välve (GH. reg. no. 6791) illustrated by NAGAO (1934, pl. 24, fig. 2). It was collected from the Hiraiga formation at Hiraiga, Tanohata village, Shimohei County, Iwate Prefecture. Other specimens described by NAGAO (1934, pl. 24, figs. 3-6, 9) are also good examples of this species. 17 more specimens (GK. H 6516-GK. H 6522, GK. H 6700-GK. H 6709) from the type area (HANAI and HAYAMI coll.) are also concerned with the description below.

Description.-Shell comparatively small, scarcely exceeding $25 \mathrm{~mm}$. in maximum length, suborbicular to subelliptical, invariably slightly longer than high, fairily strongly inflated; test thin; maximum convexity lying near the center; antero-dorsal margin broadly concave in front of the umbo; postero-dorsal margin gently convex, passing into the siphonal with a somewhat strong curvature, forming an umbonal angle of about 150 degrees with the postero-dorsal margin; anterior, ventral and posterior margins smoothly arcuate without any angulations; umbo prosogyrous, slightly rising above the dorsal margin, comparatively narrow, placed at about two-fifths of shell-length from the anterior end; lunule subequal between two valves, large, shallow, circumscribed by a weak groove, although it is actually superficial; escutcheon very narrow, defined by a sharp ridge; surface shiny, smooth except for numerous faint subinternal radial threads and concentric growth-lines; hinge plate comparatively narrow, provided with three cardinal teeth and a pair of lateral teeth of Rasatrix-type, as formulated in the generic diagnosis of Nagaoella; 3a small, thin, opisthocline; 2a thin, acline or slightly opisthocline; 1 small, almost complete, slightly prosocline; $2 \mathrm{~b}$ stout, broad, flattened at the top; $3 \mathrm{~b}$ straight, especially broad, 
distinctly bifid; 4b also straight, thin, elongated obliquely; AI and AII fairly long, placed closely to the anterior cardinal teeth, but distinctly separated from them; posterior lateral teeth and AIII slightly variable in prominence but commonly weak; ligament external, elongated along the post-umbonal margin; adductor scars subovate, weakly impressed; pallial sinus triangular, rather deep, directed at the anterior lateral teeth with an apical angle of about 60 degrees; ventral margin very finely crenulated internally in accordance with the subinternal radial threads; umbonal cavity moderate in depth.

Measurements in mm.

Specimen
Right valve (GK.H6516)
Right valve (GK.H6517)
Right valve (GK.H6518)
Left valve (GK.H6519)
Left valve (GK.H6520)
Left valve (GK.H6521)
Right valve (GK.H6522)
Right valve (GK.H6700)
Left valve (GK.H6701)
Left valve (GK.H6702)
Right valve (GK.H6703)
Left valve (GK.H6704)
Left valve (GK.H6705)
Right valve (GK.H6706)
Right valve (GK.H6707)
Left valvie (GK.H6708)
Right valve (GK.H6709)

$\begin{array}{cccc}\text { Length } & \text { Height } & \text { Thickness } & \text { L/H } \\ 17.0 & 16.0 & 5.0 & 1.06 \\ 19.0 & 18.5 & 6.0 & 1.03 \\ 21.0 & 19.5 & 6.5 & 1.08 \\ 23.0 & 21.5 & 7.0 & 1.07 \\ 18.5 & 18.0 & 5.5 & 1.03 \\ 16.0 & 15.0 & 4.5 & 1.07 \\ 17.0 & 15.5 & 4.5 & 1.10 \\ 24.5 & 19.5+ & ? & 1.26- \\ 21.5 & 19.0 & 6.0 & 1.13 \\ 19.5 & 19.0 & 6.0 & 1.03 \\ 12.5 & 11.5 & 4.0 & 1.09 \\ 24.0 & 23.0 & 7.0 & 1.04 \\ 19.5 & 17.5+ & 6.0 & 1.11- \\ 18.0 & 16.0 & 5.5 & 1.13 \\ 20.0 & 19.0 & 6.0 & 1.05 \\ 19.5+ & 19.5 & ? & 1.00+ \\ 17.0 & 15.5 & 4.0+ & 1.10\end{array}$

Observations and comparisons.--Many well preserved specimens at hand show the detailed characters of the exterior and interior. They are identical with the holotype of Dosiniopsis corrugata NAGAO, 1934, from the same area, in view of the similar outline, mode of inner ventral crenulation and dentition. Radial threads are sometimes indiscernible on the specimens from other localities than the southern coast of Hiraiga, but it is certainly due to the different state of preservation. The hinge structure is best preserved in a few of the present specimens (GK. H 6700, GK. H 6708, GK. H 6709), and it is very similar to that of the holotype. In an incomplete left valve (GK. H 6705) the musculature and marginal crenulations are well preserved.

In the dentition and shell-convexity, the present species is not much apart from Venus vectensis ForBes, 1845, from the Lower Greensand of England, which was referred to Cyprimeria (Cyclorisma) by Woods (1908) but was designated by CASEY (1952) as the type-species of Rasatrix (Vectorbis). The postero-dorsal and posterior margins are, however, better discriminated from each other in the present species than in the Lower Greensand species. Rasatrix (Rasatrix) dolobra CASEY, 1952, may be closer to the present species in the outline, but the cardinal tooth 1 of the former is distinctly opisthocline. Moreover, subinternal radial threads and marginal crenulations are unknown at all 
in those species and probably other species of Rasatrix.

Occurrence.-Lower and upper Miyakoan (Aptian to Albian). Calcareous sandstone of the Hiraiga formation at loc. Hn. 0017, 0018, southern coast of Hiraiga, at loc. Hn. 0916, north of Haipe and at loc. Hn. 1904, south of Haipe, all in Tanohata village, Shimohei County, Iwate Prefecture. Grey sandy shale of the "Orbitolina sandstone" of the Miyako group at loc. Hn. 6203 and grey calcareous sandstone of the Aketo formation at loc. Hn. 6201, northeast of Raga, the same village. Calcareous sandstone of the 2nd cycle sediments of the Miyako group at loc. Hn. 4051, Oshima, off the coast of Moshi, Iwaizumi town, the same county. Grey muddy shale of the 1st cycle sediments of the Miyako group at loc. Hn. 2065, Hideshima, Sakiyama, Miyako City, the same prefecture.

\section{Nagaoella sp. aff. N. corrugata (NAGAO)}

Plate 20, Figure 13

In the present collection there are two right valves which resembles the more or less transversely elongated specimens of Nagaoella corrugata in the outline and thin test. However, the shell-convexity is somewhat weaker and the umbo is placed more centrally than in typical specimens of $N$. corrugata. The superficial lunule is less clearly demarcated. The two specimens may represent another species of Nagaoella, but the distinction from $N$. corrugata cannot be based on the hinge and other essential characters at present. Specimens, right valves, GK. H 6531, $19.0 \mathrm{~mm}$. long, $17.0 \mathrm{~mm}$. high, $3.5 \mathrm{~mm}$. thick; GK. H 6532, $23.0 \mathrm{~mm}$. long, $20.0 \mathrm{~mm}$. high, $4.0 \mathrm{~mm}$. thick.

Occurrence.-Lower Miyakoan (Aptian). Calcareous sandstone of the Hiraiga formation at loc. Hn. 0914, 0916, north of Haipe, Tanohata village, Shimohei County, Iwate Prefecture (HAYAMI coll.).

(to be continued) 
Itaru HAYAMI

Lower Cretaceous Marine Pelecypods of Japan

Part II

Plates $7 \sim 21$ 
Plate 7 


\section{Explanation of Plate 7}

Figs. 1-3. Pseudocardia sp. cf. P. tenuicosta (Sowerby) .......... Page 77

1. Left valve (GK. H 6392) $\times 2$. Loc. 1st cycle sediments of the Miyako group at Hn. 2058, Hideshima, Miyako City. (HANAI coll.)

2. Right valve (GK. H 6394) $\times 2$. Loc. ditto. (HANAI coll.)

3. Right valve (GK. H 6393) $\times 1.5$. Loc. ditto. (HANAI coll.)

Figs. 4-7. Pseudocardia amanoi sp. nov. ........................ 79

4. Rubber cast from a left external mould (GK. H 6398) $\times 3$. Paratype. Loc. Hagino formation at Hy.6011, Hagino, Mirafu village, Kochi Pref. (OGAWA coll.)

5. Left internal mould (GK. $\mathrm{H}$ 6396) $\times 3$. Paratype. Loc. ditto. (OGAWA coll.)

6. Left internal mould (GK. H 6397) $\times 3$. Paratype. Loc. ditto. (OGAWA coll.)

7. Left internal mould (GK. H 6399) $\times 3$. Paratype. Loc. ditto. (OGAWA coll.)

Fig. 8. "Cardita" (?) sp. indet. $\ldots \ldots \ldots \ldots \ldots \ldots \ldots \ldots \ldots$.............. 80

8. Right internal mould (GK. H 6395) $\times \mathbf{1 . 5}$ Loc. 1st cycle sediments of the Miyako group at Hn. 2058, Hideshima, Miyako City. (HANAI coll.)

Figs. 9-19. Astarte (Astarte) subsenecta YABE and NAGAO ........Page 81

9. Right valve (GK. H 6773) $\times 1.5$. Loc. Haidateyama formation at U. 3095, Yamaguchi-no-tani, Mie town, Oita Pref. (FuJII coll.)

10. Both valves (GK. H 6402) $\times 1.5$. Loc. Ishido formation at $\mathrm{Hy} .4003$, Ichinose-bashi, Nakazato village, Gumma Pref. (ICHIKAWA and HAYAMI coll.). 10a: right valve; $10 \mathrm{~b}$ : left valve.

11. Left valve (GK. H 6793) $\times 1.5$. Loc. ditto. (HAYAMI coll.)

12. Rubber cast from a left external mould (GK. H 6405) $\times 1.5$. Loc. ditto. (HAYAMI coll.)

13. Left valve (GK. H 6794) $\times 1.5$. Loc. ditto. (HAYAMI coll.)

14. Right valve (GK. H 6795) $\times 1.5$. Loc. ditto. (HAYAMI coll.)

15. Right valve (GK. H 6401) $\times 1.5$. Loc. ditto. (ICHIKAWA and HaYamI coll.)

16. Left internal mould (GK. H 6649) $\times 1.5$. Loc. ditto. (SUGITA and HaYAMI coll.)

17. Right internal mould (GK. H 6406) $\times 1.5$. Loc. ditto. (ICHIKAWA and HAYAMI coll.)

18. Left internal mould (GK. H 6403) $\times 1.5$. Loc. ditto. (ICHIKAWA and HAYAMI coll.)

19. Left internal mould (GK. H 6404) $\times 1.5$. Loc. ditto. (ICHIKAWA and HAYAMI coll.)

All specimens illustrated are kept in the Department of Geology, Kyushu University. 

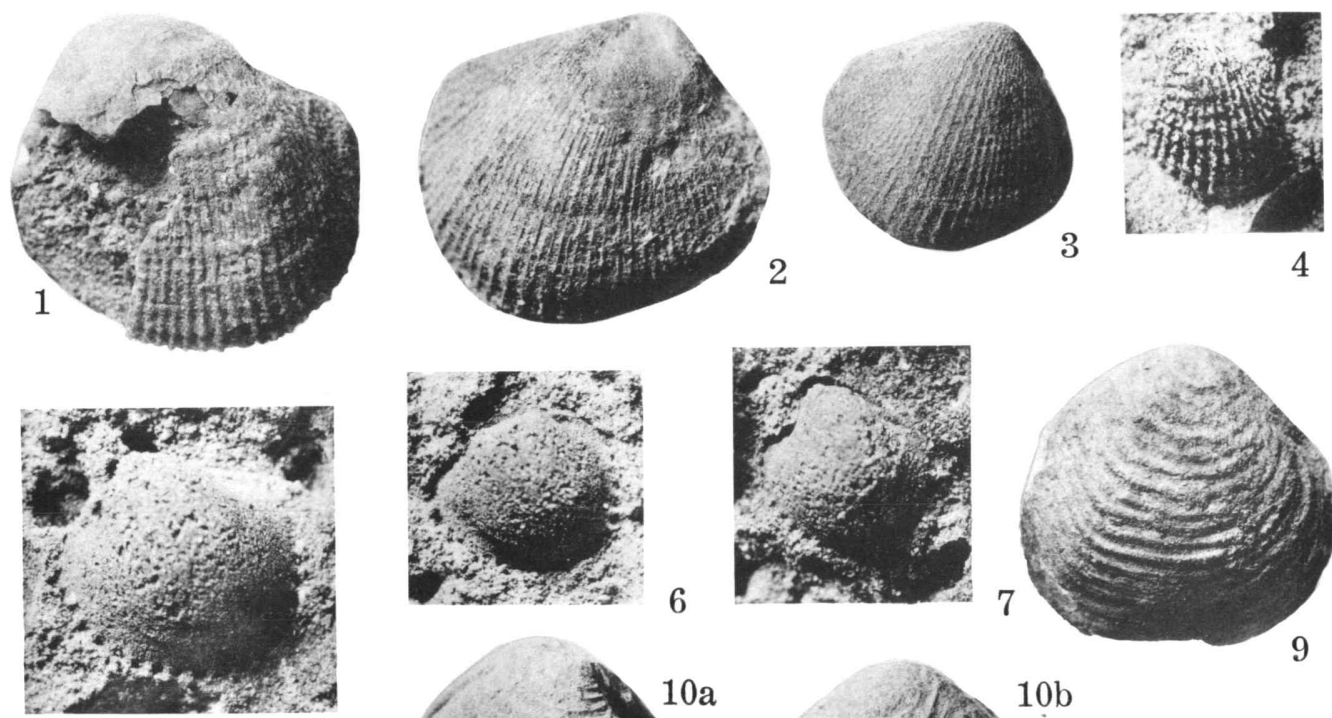

5
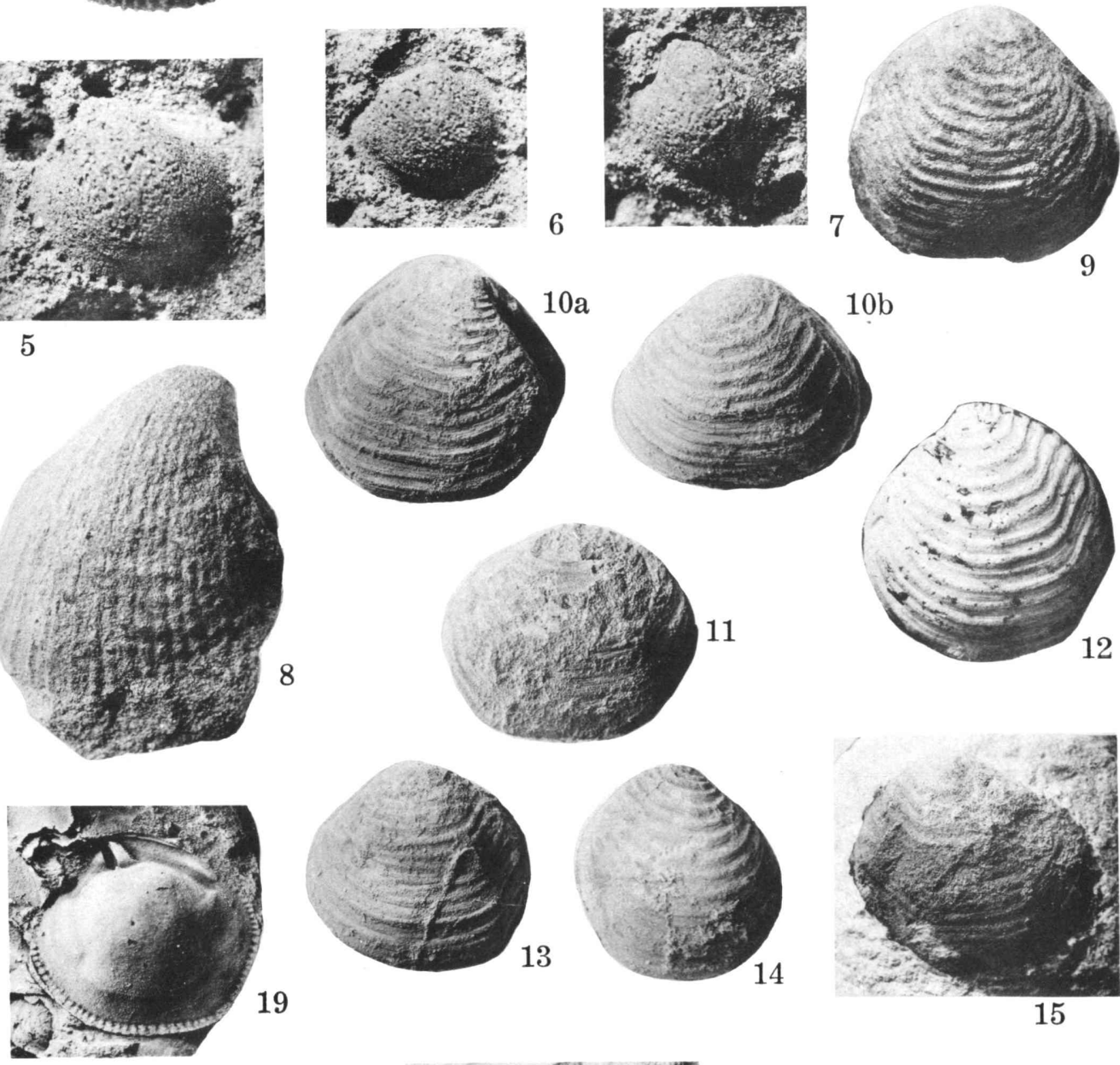

15
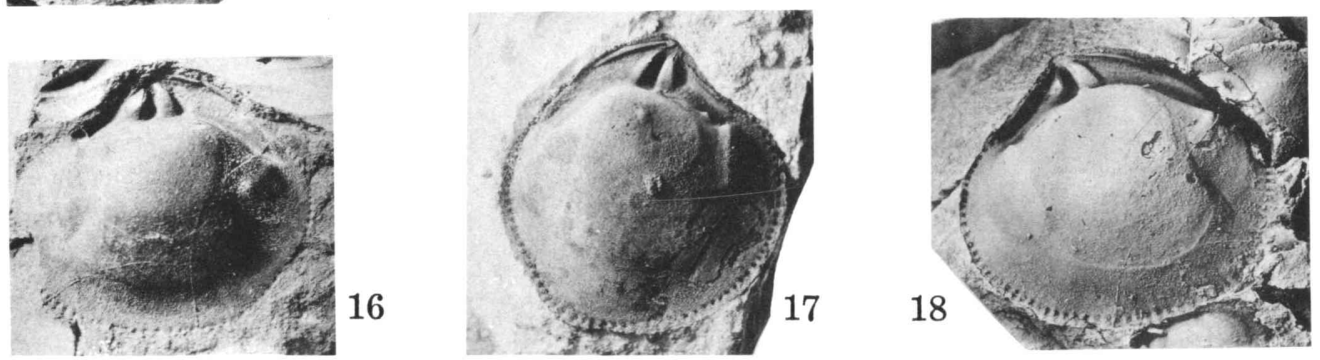

I. HAYAmi: Lower Cretaceous marine Pelecypods of Japan 
Plate 8 


\section{Explanation of Plate 8}

Figs. 1, 2. Astarte (Astarte) costata YABE and NAGAo ........... Page 85

1. Left valve (GK. H 6409) $\times 1.5$. Loc. Choshi formation at Hy. 2001, Ashikajima, Choshi City (HAYAMI coll.)

2. Left valve (GK. H 6408) $\times 1.5$. Loe. Ishido formation at $\mathrm{Hy} .4003$, Ichinose-bashi, Nakazato village, Gumma Prefecture (ICHIKAWA and HAYAMI coll.)

Figs. 3-10. Astarte (Astarte) semicostata NaGAo ............Page 86

3. Left internal mould (GK. H 6415) $\times 3$. Loc. Hiraiga formation at $H$. 0018, south of Hiraiga, Tanohata village, Iwate Pref. (HAYAMI coll.)

4. Right valve (GK. H 6413) $\times 3$. Loc. ditto. (HAYAMI coll.)

5. Right valve (GK. H 6412) $\times 3$. Loc. Hiraiga formation at Hn. 0017, south of Hiraiga (HANAI and HAYAMI coll.)

6. Right valve (GK. H 6656) $\times 3$. Loc. Hiraiga formation at Hn. 0916, Haipe, Tanohata village (HANAI and HAYAMI coll.)

7. Right valve (GK. H 6654) $\times 3$. Loc. ditto. (HANAI and HaYami coll.)

8. Both valves (GK. H 6410) $\times 3$. Loc. Hiraiga formation at $\mathrm{Hn} .0018$, south of Hiraiga. (HAYAMI coll.)

9. Both valves (GK. H 6411) $\times 3$. Loc. ditto. (HayamI coll.) 9a: right valve; 9b: left valve; 9c: upper view.

10. Right valve (GK. H 6653) $\times 3$. Loc. ditto. (HAYAMI coll.)

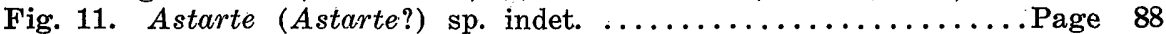

11. Left valve (GK. H 6587) $\times 2$. Loc. Oshima formation at Hy. 0012, south of Yokonuma, Oshima, Kesennuma City (OBATA and HAYAMI coll.)

Figs. 12-18. Astarte (Freiastarte) subomalioides NAGAo ...........Page 88

12. Left valve (GK. H 6417) $\times 2$. Loc. Hiraiga formation at $\ddot{H}$. 0018, south of Hiraiga, Tanohata village, Iwate Pref. (HAYAMI coll.)

13. Left valve (GK. H 6419) $\times 2$. Loc. ditto. (HAYAMI coll.)

14. Left valve (GK. H 6420) $\times 2$. Loc. ditto. (HANAI and HaYAMI coll.)

15. Right valve (GK. H 6421) $\times 2$. Loc. ditto. (HANAI and HAYAMI coll.)

16. Left valve (GK. H 6657) $\times 2$. Loc. ditto. (HANAI and HAYAMI coll.)

17. Right valve (GK. H 6418) $\times 2$. Loc. ditto. (HAYAMI coll.)

18. Right valve (GK. H 6658) $\times 2$. Loc. ditto. (HANAI and Hayami coll.)

Figs. 19-22. Astarte (Nicaniella) minor NAGAo ...................... 91

19. Right valve (GK. H 6427) $\times 3$. Loc. Hiraiga formation at Hn. 0916, Haipe, Tanohata village, Iwate Pref. (HAYAMI coll.)

20. Right valve (GK. H 6663) $\times 3$. Loc. Hiraiga formation at Hn. 0017, south of Hiraiga, Tanohata village. (HANAI and HAYAMI coll.)

21. Both valves (GK. H 6429) $\times 3$. Loc. Hiraiga formation at Hn. 0914, Haipe, Tanohata village. (HANAI and HAYAMI coll.) 21a: left valve; 21b: right valve; 21c: upper view.

22. Both valves (GK. H 6425) $\times 3$. Loc. Hiraiga formation at Hn. 0018, south of Hiraiga, Tanohata village. (HAYAMI coll.) 22a: left valve; 22b: right valve; 22c: upper view.

Fig. 23. Astarte (Astarte) semicostata NAGAO ? ................ Page 86

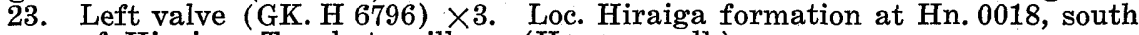
of Hiraiga, Tanohata village (HAYAMr coll.)

Fig. 24. Astarte (Freiastarte) cf. A. (F.) subomalioides NaGao . ..Page 90

24. Left internal mould (GK. H 6423) $\times 1.5$. Loc. Yatsushiro formation at Km. 3037, Miyaji, Yatsushiro City (KANMrena coll.)

Figs. 25, 26. Astarte (Yabea) shimanoensis YABE and NAGAo ..... Page 93

25a. Left internal mould (GK. H 6652) $\times 1.5$. Loc. Ishido formation at $\mathrm{Hy}$. 4003, Ichinose-bashi, Nakazato village, Gumma Pref. (IcHrKAWA and HAYAMI coll.)

25b. Plaster cast from the same external mould, $\times 1.5$.

26. Right internal mould (GK. H 6430) $\times 1.5$. Loc. ditto. (ICHIKAWA and HAYAMI coll.)

All specimens illustrated are kept in the Department of Geology, Kyushu University. 


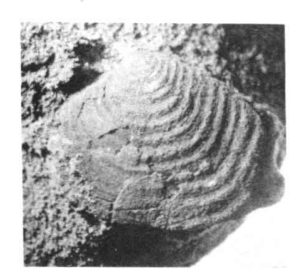

1
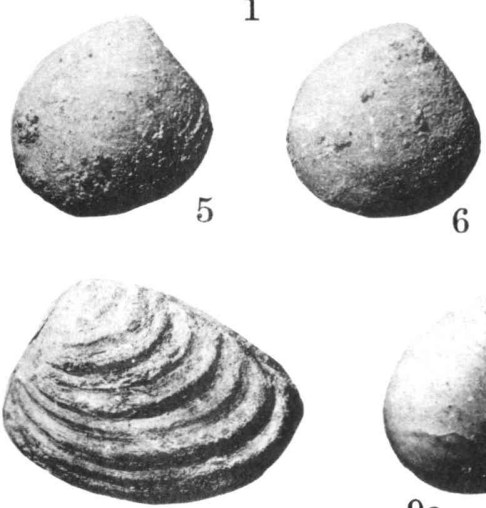

11

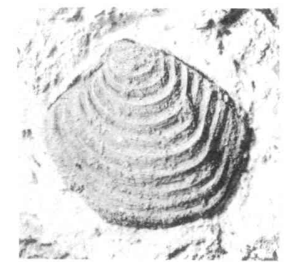

2
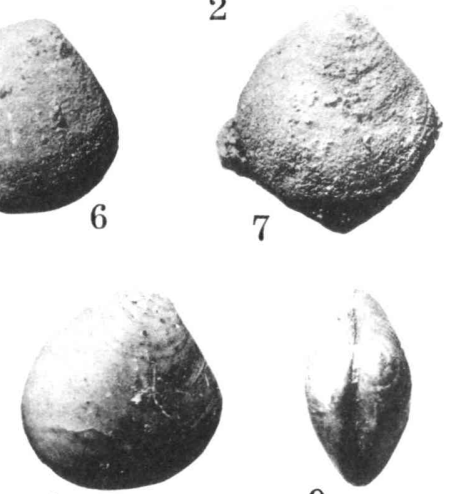

9a

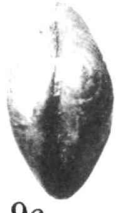

$9 \mathrm{c}$

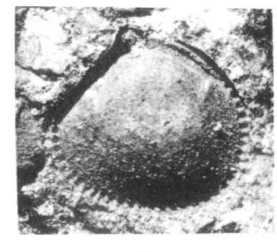

3

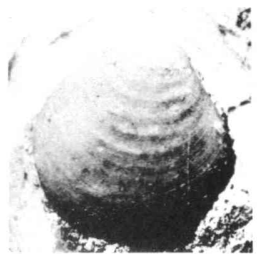

4
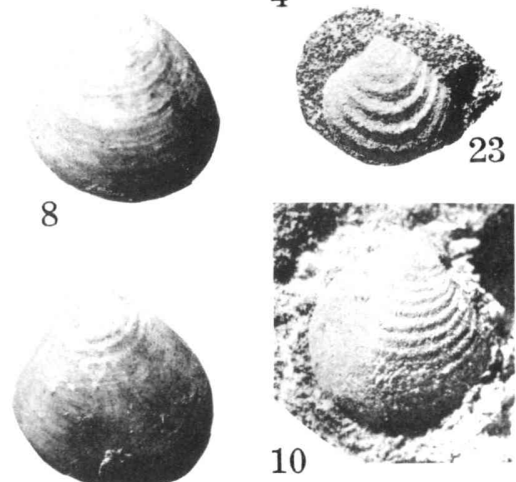

$9 b$
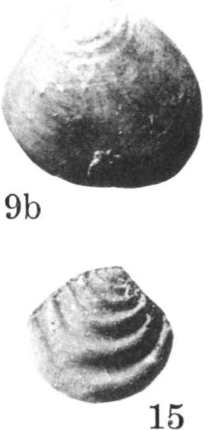

15

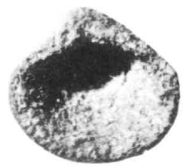

19

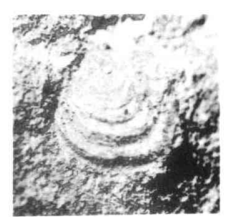

24

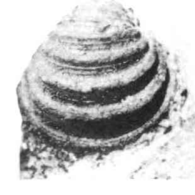

20

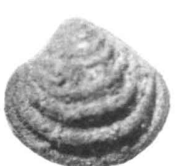

$21 \mathrm{a}$

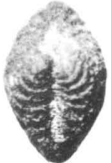

$21 \mathrm{c}$

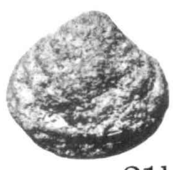

$21 b$
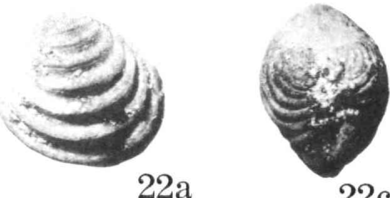

$22 \mathrm{c}$

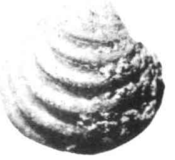

$22 \mathrm{~b}$
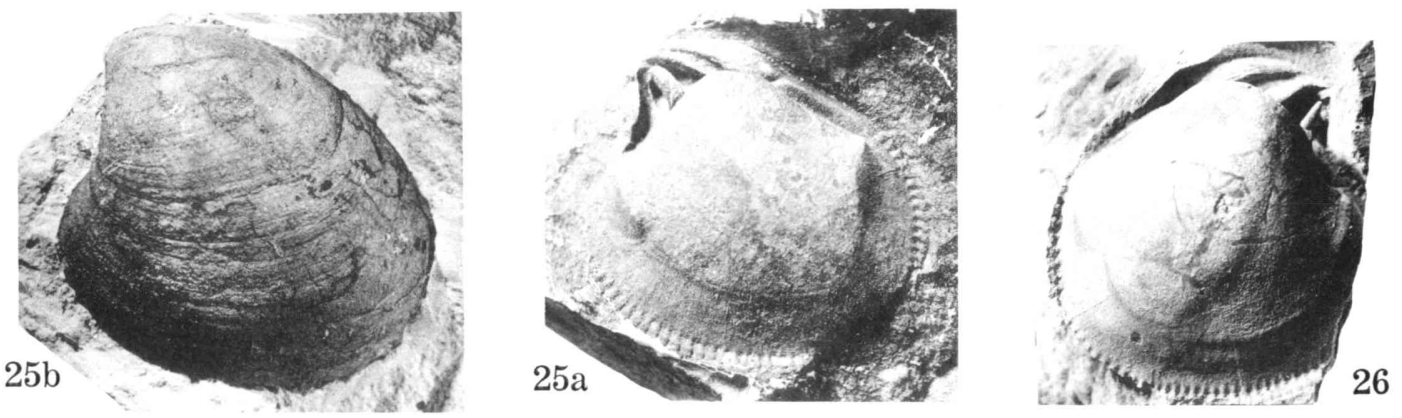

I. Hayami : Lower Cretaceous marine Pelecypods of Japan 


\section{Plate 9}




\section{Explanation of Plate 9}

Fig. 1. Astarte (Yabea) sp. aff. A. (Y.) shinanoensis YABE and NAGAO .....

....Page 94

1. Left internal mould (GK. $H$ 6774) $\times 1.5$. Loc. Hanoura formation at Hy. 5002, Hiroyasu, Katsuura town, Tokushima Pref. (HAYAMI coll.)

Figs. 2-5. Astarte (Yabea) akatsui sp. nov. ........................ 95

2. Left internal mould (GK. H 6171) $\times 1.5$. Holotype. Loc. Yatsushiro formation at At. 328, south of Bisho, Toyo village, Kumamoto Pref. (AKATSU coll.)

3. Right internal mould (GK. H 6173) $\times 1.5$. Paratype. Loc. ditto. (AKATSU coll.)

4. Right internal mould (GK. H 6174) $\times 1$. Paratype. Loc. ditto. (AKatsu coll.)

5. Right internal mould (GK. H 6175) $\times 1$. Paratype. Loc. ditto. (AKATSU coll.)

Figs. 6-12. Eriphyla (Eriphyla) pulchella sp. nov. ................ 98

6. Right valve (GK. H 6442). Holotype. Loc. "Orbitolina sandstone" of the Miyako group at Hn. 6203, northeast of Raga, Tanohata village, Iwate Pref. (HANAI and HAYAMI coll.) 6a: lateral view $(\times 1.5) ; 6 \mathrm{~b}$ : upper view $(\times 1.5)$; $6 c$ : lateral view $(\times 2)$.

7. Both valves (GK. H 6448) $\times 2$. Loc. ditto. (HanaI and Hayami coll.)

8. Right valve (GK. H 6447) $\times 2$. Paratype. Loc. ditto. (HANaI and Hayami coll.)

9. Right internal mould (GK. H 6446) $\times 1.5$. Paratype. Loc. ditto. (HANAI and HaYAMI coll.)

10. Right valve (GK. H 6443) $\times 2$. Paratype. Loc. ditto. (HANAI and HAYAMI coll.)

11. Right valve (GK. H 6444) $\times 2$. Paratype. Loc. ditto. (HanaI and Hayami coll.)

12. Both valves (GK. H 6445$) \times 2$. Paratype. Loc. ditto. (HanaI and HayamI coll.) 12a: right valve; $12 \mathrm{~b}$ : left valve; $12 \mathrm{c}$ : upper view.

Figs. 13-16. Eriphyla (Eriphyla) minima sp. nov. .................. 99

13. Left internal mould (GK. H 6182) $\times 2$. Paratype. Loc. Yatsushiro formation at At. 328, south of Bisho, Toyo village, Kumamoto Pref. (AKATsU coll.)

14. Left internal mould (GK. H 6184) $\times 1.5$. Paratype. Loc. ditto. (AxatSU coll.)

15. Left internal mould (15a) and its rubber cast (15b) (GK. H 6181) $\times 2$. Holotype. Loc. ditto. (AKATSU coll.)

16. Left internal mould (GK. H 6449) $\times 1.5$. Paratype. Loc. Ishido formation at Hy. 4003, Ichinose-bashi, Nakazato village, Gumma Pref. (HAYAMI coll.)

Fig. 17. Opis (Opis) sp. indet. ................................. 106

17. Left internal mould (GK. H 6775) $\times 2$. Loc. Hiraiga formation at $\mathrm{Hn}$. 0017, south of Hiraiga, Tanohata village, Iwate Pref. (HAYAMI coll.)

All specimens illustrated are kept in the Department of Geology, Kyushu University. 

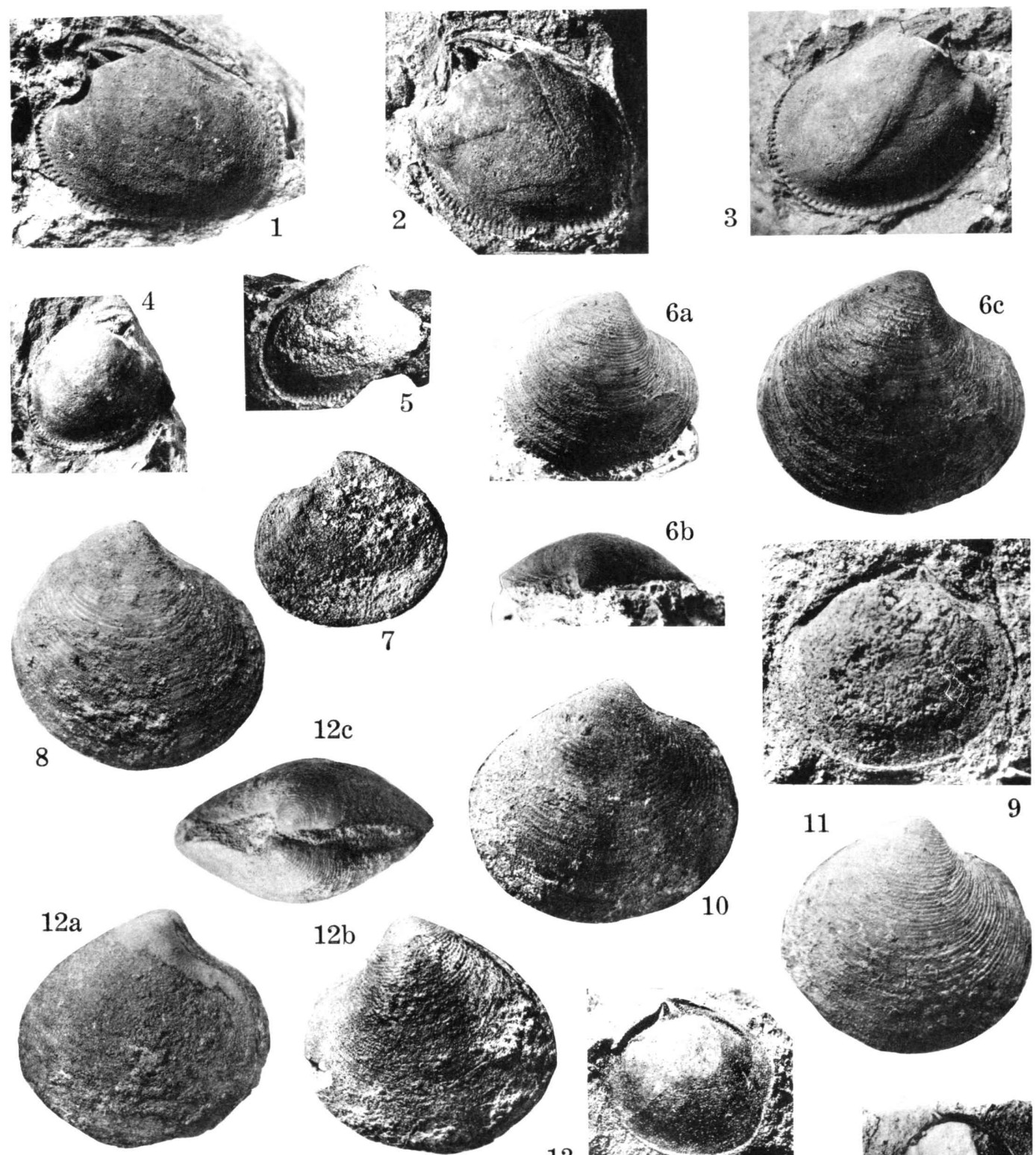

13
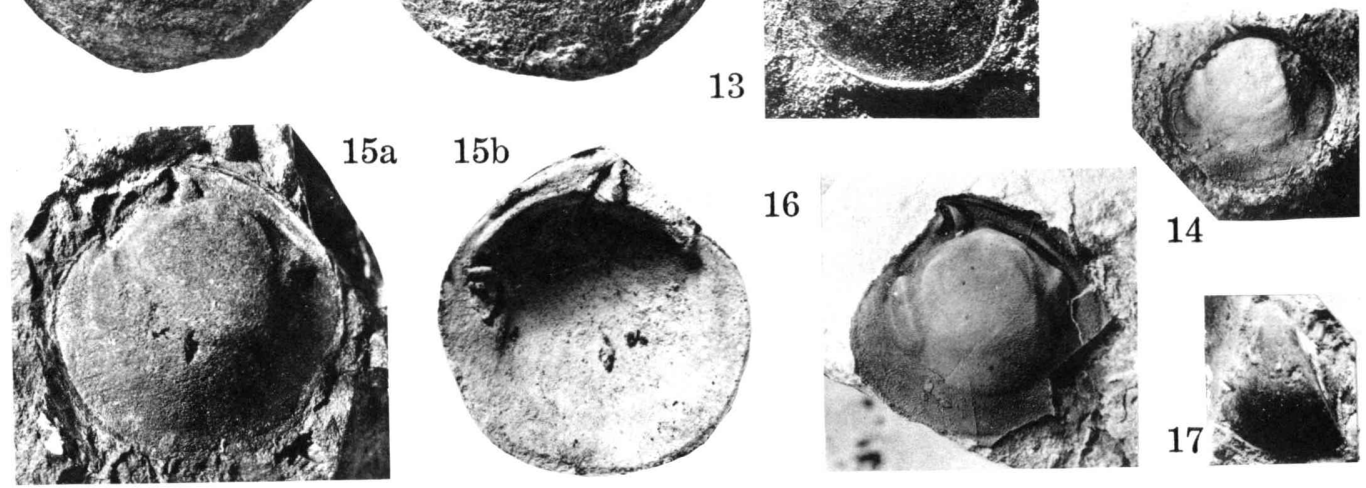
14

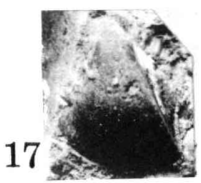

I. HAyAmi: Lower Cretaceous marine Pelecypods of Japan 
Plate 10 


\section{Explanation of Plate 10}

Figs. 1-9. Eriphyla (Miyakoella) miyakoensis (NAGAo) ............ 101

1. Both valves (GK. H 6432) $\times 1$. Loc. Hiraiga formation at Hn. 0018, south of Hiraiga, Tanohata village, Iwate Pref. (HANAI and HAYAMI coll.) 1a: left valve; $1 \mathrm{~b}$ : right valve; $1 \mathrm{c}$ : anterior view; $1 \mathrm{~d}$ : upper view.

2. Both valves $($ GK. H 6665) $\times 1$. Loc. Hiraiga formation at Hn. 0911, Haipe, the same village. (HANAI coll.) $2 \mathrm{a}$ : left valve; $2 \mathrm{~b}$ : right valve; 2c: upper view.

3. Both valves (GK. H 6441) $\times 1$. Loc. Hiraiga formation at Hn. 0010, south of Hiraiga, the same village. (HANAI coll.) $3 \mathrm{a}$ : left valve; $3 \mathrm{~b}$ : right valve.

4. Right valve (GK. H 6797) $\times 1$. Loc. Hiraiga formation at Hn. 0017, south of Hiraiga, the same village. (HAYAMI coll.)

5. Right valve (GK. H 6433) $\times 1$. Loc. Hiraiga formation (boulder) at the south of Hiraiga, the same village. (HAYAMI coll.)

6. Left valve (GK. H 6435) $\times 1$. Loc. ditto. (Hayami coll.)

7. Right valve (GK. H 6436). Loc. Hiraiga formation at $\mathrm{Hn} .0017$, south of Hiraiga, the same village (HAYAMI coll.) 7a: internal view $(\times 1)$; $7 \mathrm{~b}$ : external view $(\times 1) ; 7 \mathrm{c}$ : upper view $(\times 1) ; 7 \mathrm{~d}$ : internal view $(\times 2)$.

8. Left valve (GK. H 6437). Loc. Tanohata formation at Hn. 0802, Koikorobe, the same village. (HANAI and HAYAMI coll.) 8a: internal view $(\times 1) ; 8 \mathrm{~b}$ : internal view $(\times 2)$.

9. Left valve (GK. H 6438) $\times 1$. Loc. ditto. (HANAI and HaYami coll.)

All specimens illustrated are kept in the Department of Geology, Kyushu University. 

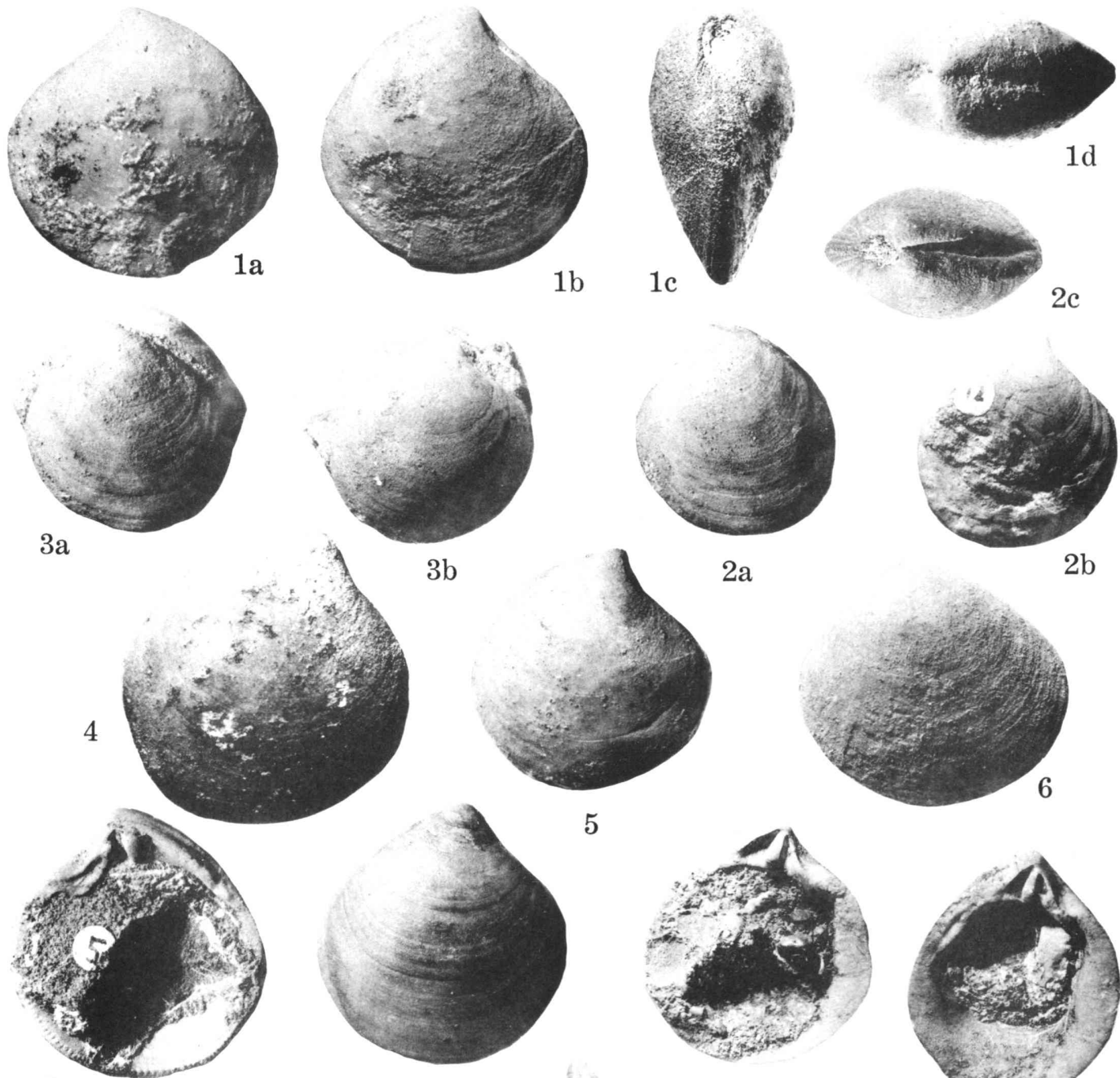

$2 \mathrm{a}$

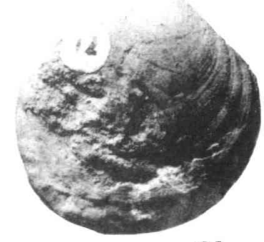

$7 \mathrm{a}$

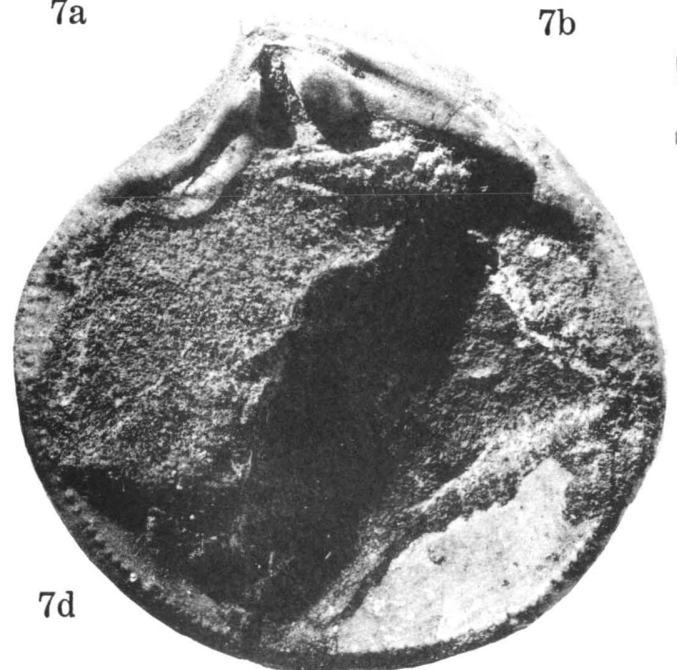

5

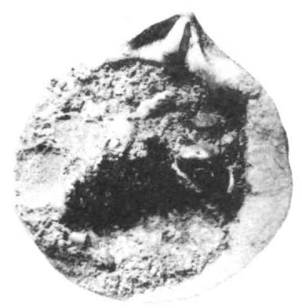

$8 \mathrm{a}$
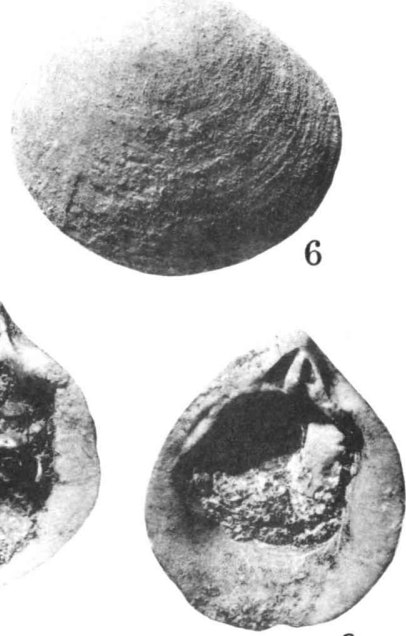

9
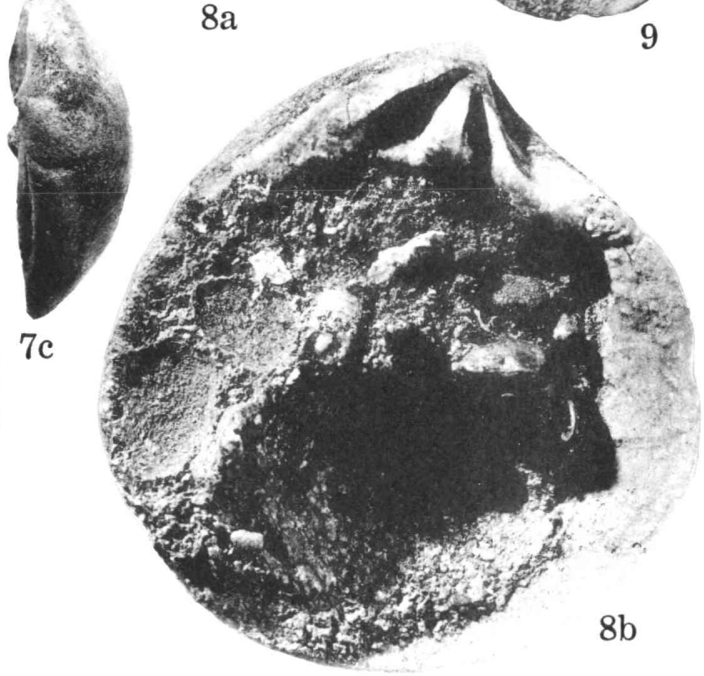

I. HAYAmi : Lower Cretaceous marine Pelecypods of Japan 
Plate 11 


\section{Explanation of Plate 11}

Figs. 1-8. Eriphyla (Miyakoella) miyakoensis (NAGA0) ........... 101

1. Right valve (GK. H 6434) $\times 1$. Loc. Tanohata formation at Hn. 0802, Koikorobe, Tanohata village, Iwate Pref. (HANAI and Hayami coll.)

2. Left valve (GK. H 6440) $\times 1$. Loc. ditto. (HANAI and HAYAMI coll.)

3. Both valves (GK. H 6668) $\times 1.5$. Loc. Aketo formation at Hn. 6201, northeast of Raga, the same village (HANAI coll.) $3 a$ : right valve; $3 b$ : left valve.

4. Both valves (GK. H 6670) $\times 1$. Loc. Aketo formation at $\mathrm{Hn} .0671$, northeast of Raga, the same village (HANAI and HAYAMI coll.) 4a: right valve; $4 \mathrm{~b}$ : left valve.

5. Right internal mould showing the presence of a shallow pallial sinus (GK. H 6439) $\times 1.5$. Loc. Hiraiga formation at $\mathrm{Hn} .0017$, south of Hiraiga, the same village. (HAYAMI coll.)

6. Right valve (GK. H 6664) $\times 1$. Loc. Hiraiga formation at Hn. 0911, Haipe, the same village. (HANAI coll.)

7. Left valve (GK. H 6667) $\times 1.2$. Loc. 2 nd cycle sediments of the Miyako group at Hn. 4051, Oshima, off the coast of Moshi, Iwaizumi town, Iwate Pref. (Hanai and Hayami coll.)

8. Right valve $($ GK. H 6669) $\times 1.08$. Loc. Hiraiga formation (boulder) at the south of Hiraiga, Tanohata village. (HAYAmI coll.)

Figs. 9, 10. Astarte (Astarte) sp. cf. A. (A.) subsenecta YABE and NAGAO

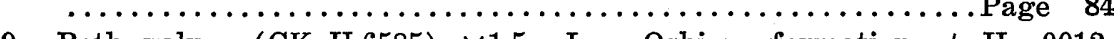

9. Both valves (GK. H 6585) $\times 1.5$. Loc. Oshima formation at Hy. 0012, Yokonuma of Oshima, Kesennuma City. (OBATA and Hayami coll.) 9a: left valve; $9 \mathrm{~b}$ : right valve.

10. Left valve (GK. H 6584) $\times 1.5$. Loc. ditto. (OBATA and HaYAmi coll.)

Figs. 11, 12. Opis (Opis) nakanoi sp. nov. ...................... 105

11. Right valve (GK. H 6452) $\times 1$. Paratype. Loc. 1st cycle sediments of the Miyako group at the coast of Hideshima, Miyako City. (Nakano coll.)

12. Right valve (GK. H 6451) $\times 1.5$. Holotype. Loc. ditto. (Nakano coll.) 12a: external view; $12 b$ : internal view.

All specimens illustrated are kept in the Department of Geology, Kyushu University. 

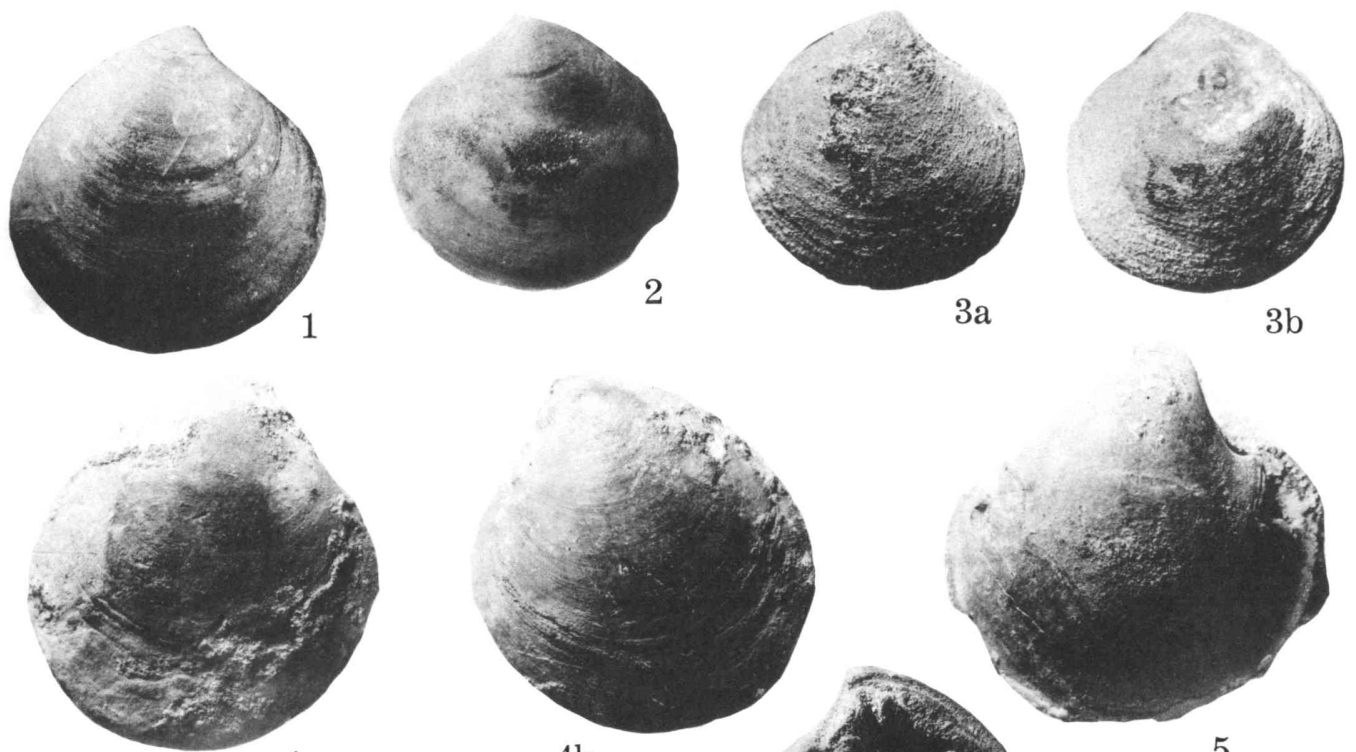

$4 a$

$4 \mathrm{~b}$
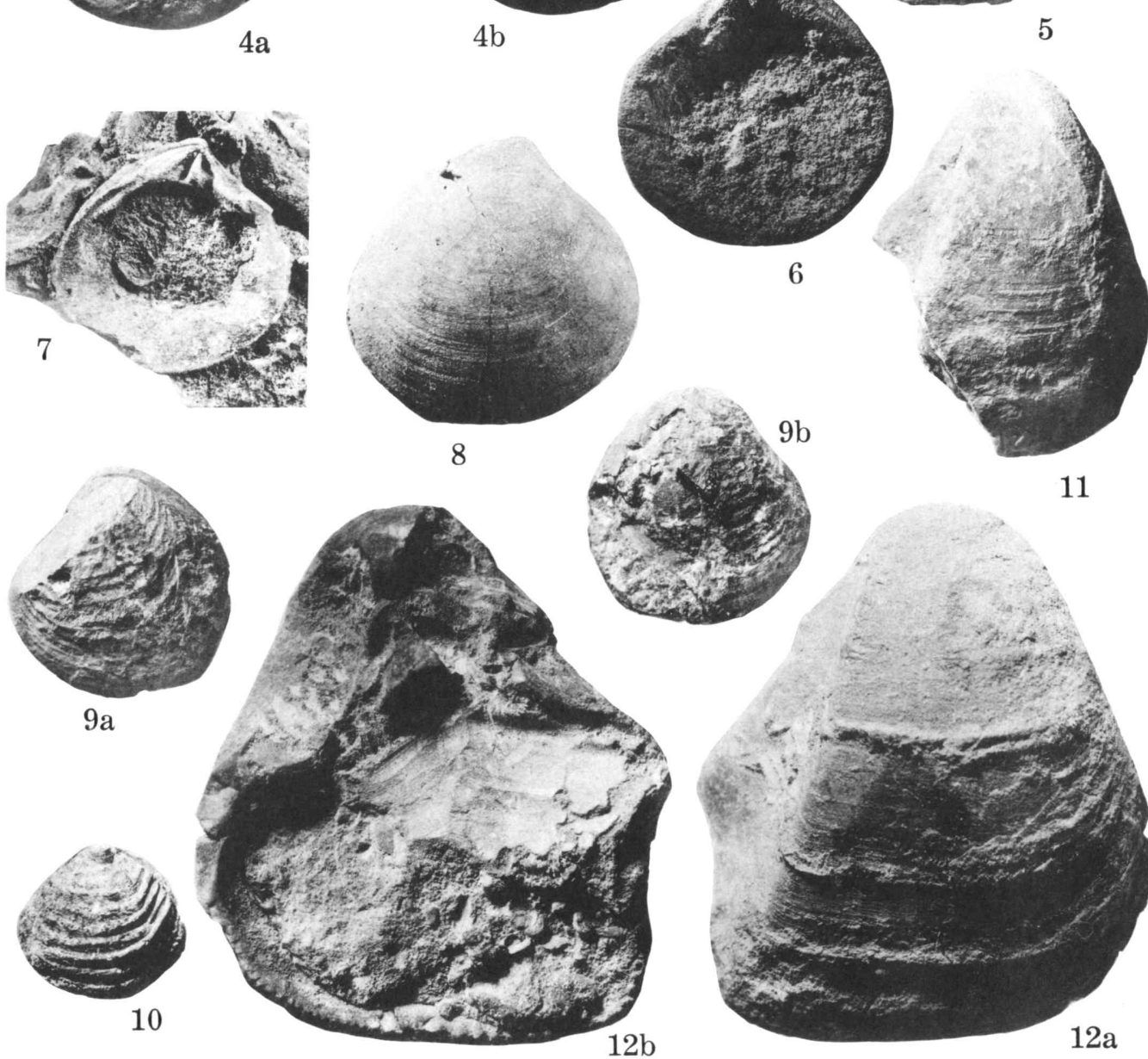

11

$2 \mathrm{~b}$

$12 \mathrm{a}$

I. HAyAmi: Lower Cretaceous marine Pelecypods of Japan 
Plate 12 


\section{Explanation of Plate 12}

Figs. 1-10. Anthonya subcantiana NAGA0 ....................... 110

1. Left valve (GK. H 6470) $\times 2$. Loc. Hiraiga formation (boulder) at the south of Hiraiga, Tanohata village, Iwate Pref. (HAyami coll.)

2. Left internal mould (GK. H 6786) $\times 2$. Loc. Hiraiga formation at $\mathrm{Hn}$. 0018 , the same village. (HAYAMI coll.)

3. Right internal mould (GK. H 6785) $\times 2$. Loc. ditto. (Hayami coll.)

4. Right valve showing internal characters $($ GK. H 6464) $\times 2$. Loc. Hiraiga formation (boulder) at Haipe, the same village. (HANAI coll.)

5. Left valve (GK. H 6469) $\times 2$. Loc. Hiraiga formation at Hn. 0018, the same village. (HANAI and HAYAMI coll.)

6. Left valve (GK. H 6471) $\times 2$. Loc. ditto. (HaNaI and HaYami coll.)

7. Left valve (GK. H 6465) $\times 2$. Loc. ditto. (HANAI and Hayami coll.)

8. Right valve (GK. H 6467) $\times 2$. Loc. ditto. (HANAI and HAYAMI coll.)

9. Right valve (GK. H 6468) $\times 2$. Loc. ditto. (HANAI and HAYAMI coll.)

10. Left valve (GK. H 6783) $\times 2$. Loc. Hiraiga formation at $\mathrm{Hn} .0017$, south of Hiraiga, the same village (HAYAMI coll.)

Fig. 11. Part of a slab with Anthonya subcantiana NAGAo (11a), Neithea (Neithea) ficalhoi (CHOFFAT) (11b) and Goniomya subarchiaci NAGAO (11c) $\times 2$.

11a. Right valve (GK. H 6671) $\times 2$. Loc. ditto. (HANAI and Hayami coll.)

All specimens illustrated are kept in the Department of Geology, Kyushu University. 


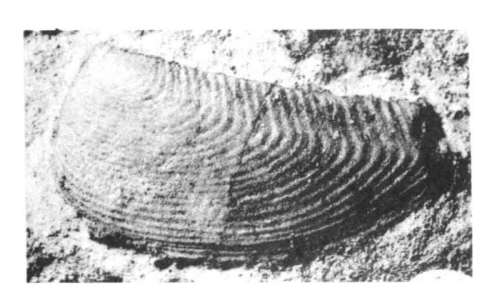

1

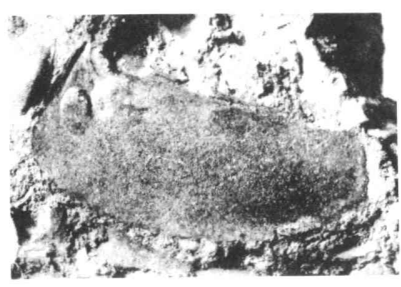

2

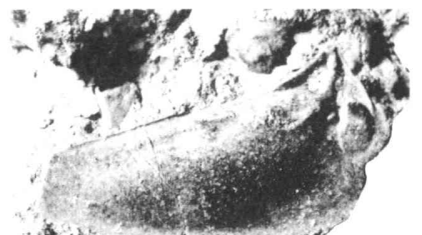

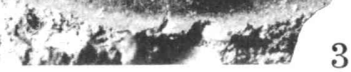

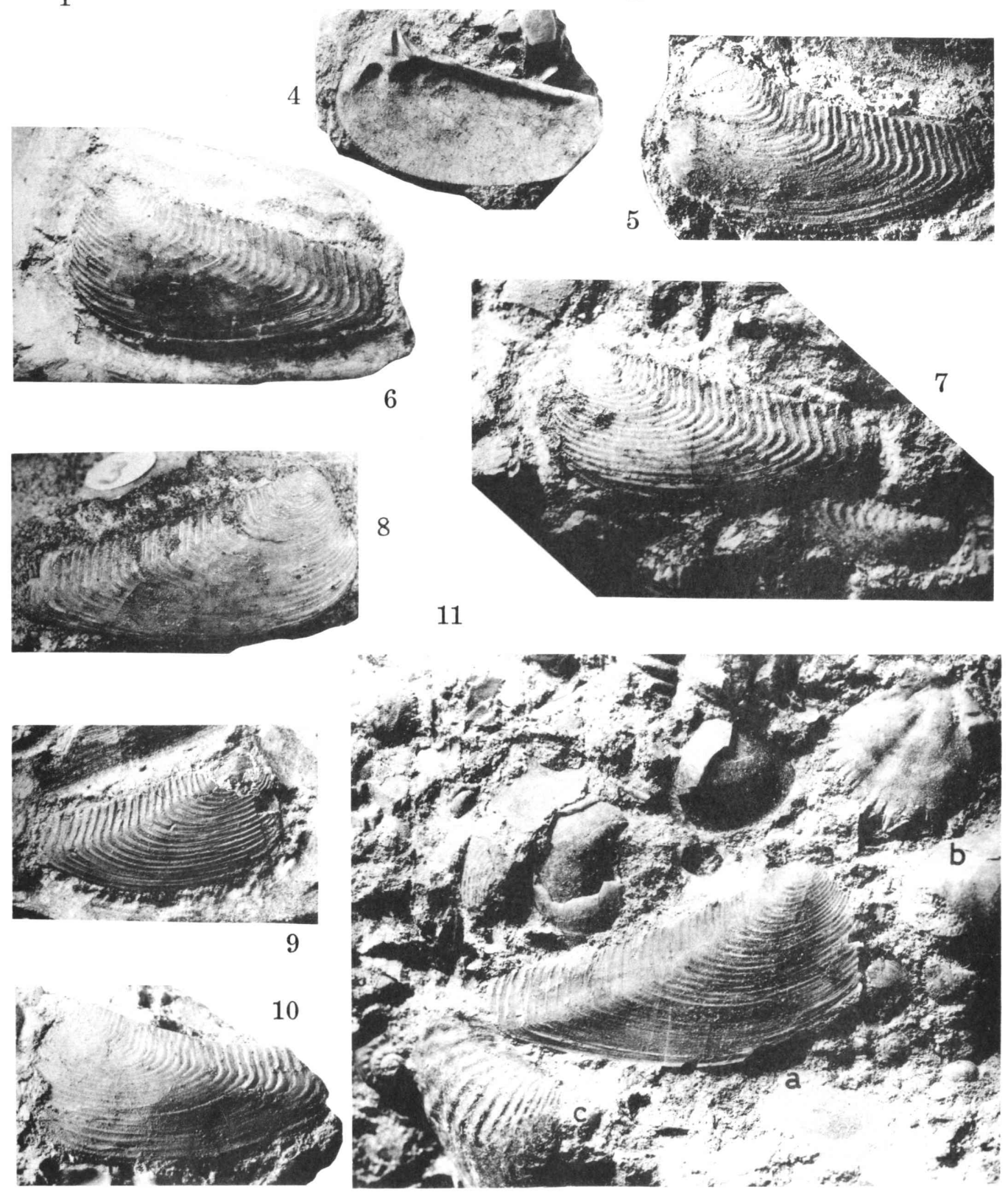

I. Hayami: Lower Cretaceous marine Pelecypods of Japan 
Plate 13 


\section{Explanation of Plate 13}

Fig. 1. Myoconcha modesta sp. nov. .............................. 76

1. Left valve (GK. H 6391) $\times$ 1.5. Holotype. Loc. Tanohata formation at Hn. 0803, Koikorobe, Tanohata village, Iwate Pref. (HANAI and HAYAMI coll.) 1a: internal view; $1 \mathrm{~b}$ : external view.

Figs. 2-5. Anthonya subcantiana NAGAo ........................... 110

2. Right valve (GK. H 6784) $\times 2$. Loc. Hiraiga formation (boulder) at the south of Hiraiga, the same village. (HANAI coll.)

3. Left valve (GK. H 6672) $\times 2$. Loc. ditto. (HaYami coll.)

4. Left valve (GK. H 6466) $\times 2$. Loc. ditto. (HAYAMI coll.)

5. Left valve (GK. H 6787) $\times 2$. Loc. Hiraiga formation at Hn. 0018, south of Hiraiga, the same village. (HANAI and HaYAMI coll.)

Fig. 6. Anthonya sp. aff. A. subcantiana NAGAo ................ Page 113

6. Left internal mould (GK. H 6475) $\times 2$. Loc. Ishido formation at $\mathrm{Hy}$. 4001, Ichinose-bashi, Nakazato village, Gumma Pref. (IchIKawa and HAYAMI coll.)

Figs. 7-11. Pachythaerus kagaharensis (Yokoyama) .............Page 107

7. Right internal mould (GK. H 6453) $\times 1.5$. Loc. ditto. (IcHIKAWA and HAYAMI coll.)

8. Both valves (GK. H 6456) $\times 1.5$. Loc. ditto. (ICHIKAWA and HAYAMI coll.)

9. Left valve (GK. H 6457) $\times$ 1.5. Loc. ditto. (ICHIKAWA and Hayami coll.)

10. Left internal mould (GK. H 6455) $\times 1.5$. Loc. ditto. (ICHIKAWA and HAYAMI coll.)

11. Right internal mould (GK. H 6454) $\times$ 1.5. Loc. ditto. (ICHIKAWA and HAYAMI coll.)

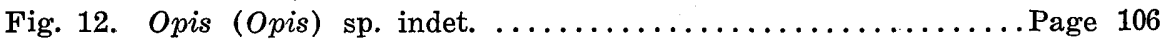

12. Rubber cast from a left external mould $(\mathrm{GK} . \mathrm{H} 6775) \times 2$. Loc. Hiraiga formation at $\mathrm{Hn} .0017$, south of Hiraiga, Tanohata village, Iwate Pref. (HAYAMI coll.) Same individual illustrated in Plate 3, Fig. 16.

All specimens illustrated are kept in the Department of Geology, Kyushu University. 

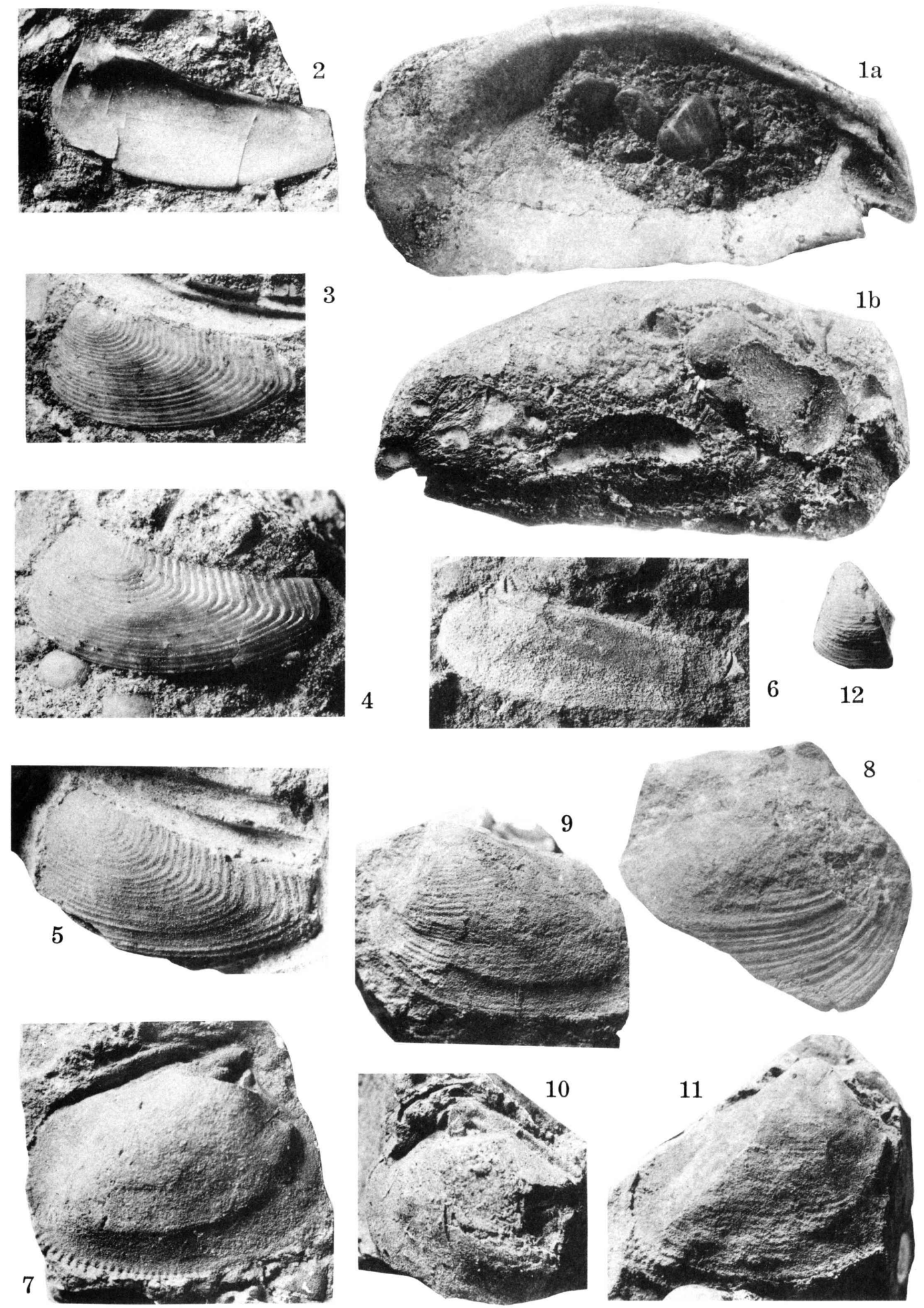

I. HAYAmi : Lower Cretaceous marine Pelecypods of Japan 
Plate 14 


\section{Explanation of Plate 14}

Figs. 1-5. Astarte (Astarte) subsenecta $\mathrm{Y}_{\mathrm{ABE}}$ and NAGAo .........Page 81

1. Rubber cast from a left internal mould (GK. H 6403, pl. 7, fig. 18) $\times 1.5$. Loc. Ishido formation at Hy. 4003, Ichinose-bashi, Nakazato village, Gumma Pref. (Ichikawa and Hayami coll.)

2. Rubber cast from a right internal mould (GK. H 6406, pl. 7, fig. 17) $\times 1.5$. Loc. ditto. (ICHIKAWA and HAYAMI coll.)

3. Rubber cast from a left internal mould (GK. H 6648) $\times 1.5$. Loc. ditto. (ICHIKAWA and HAYAMI coll.)

4. Rubber cast from a left internal mould (GK. H 6404, pl.1, fig. 19) $\times 1.5$. Loc. ditto. (ICHIKAWA and HAYAMI coll.)

5. Rubber cast from a left internal mould (GK. H 6649) $\times 1.5$. Loc. ditto. (ICHIKAWA and HaYAMI coll.)

Fig. 6. Eriphyla (Eriphyla) pulchella sp. nov. .................. 98

6. Rubber cast from a right internal mould (GK. H 6446, pl.9, fig. 9) $\times 2$. Paratype. Loc. "Orbitolina sandstone" of the Miyako group at Hn. 6203, northeast of Raga, Tanohata village, Iwate Pref. (HANAI and HAYAMI coll.)

Figs. 7, 8. Astarte (Yabea) shinanoensis YABE and NAGAO ........Page 93

7. Rubber cast from a right internal mould (GK. H 6430, pl. 8, fig. 25) $\times 1.5$. Loc. Ishido formation at Hy. 4003, Ichinose-bashi, Nakazato village, Gumma Pref. (IchiKaWA and Hayami coll.)

8. Rubber cast from a left internal mould (GK. H 6652, pl. 8, fig. 26) $\times 1.5$. Loc. ditto. (ICHIKaWA and Hayami coll.)

Fig. 9. Astarte (Yabea) sp. aff. A. (Y.) shinanoensis YABE and NAGAo ....

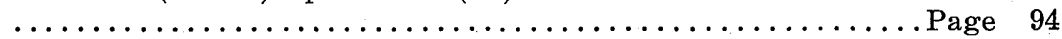

9. Rubber cast from a left internal mould (GK. H 6774, p1.9, fig. 1) $\times 1.5$. Loc. Hanoura formation at Hy. 5002, Hiroyasu, Katsuura town, Tokushima Pref. (HAYAMI coll.)

Figs. 10, 11. Astarte (Yabea) akatsui sp. nov. .................... 95

10. Rubber cast from a left internal mould (GK. H 6171, pl. 9, fig. 2) $\times 1.5$. Holotype. Loc. Yatsushiro formation at At. 328, Bisho, Toyo village, Kumamoto Pref. (AKATsu coll.)

11. Rubber cast from a right internal mould (GK. H 6174, pl. 9, fig. 4) $\times 1.5$. Paratype. Loc. ditto. (AKATsU coll.)

Figs. 12, 13. Eriphyla (Eriphyla) minima sp. nov. .............. 99

12. Rubber cast from a left internal mould (GK. H 6449, pl. 9, fig. 16) $\times 1.5$. Paratype. Loc. Ishido formation at Hy. 4003, Ichinose-bashi, Nakazato village, Gumma Pref. (HaYami coll.)

13. Rubber cast from a left internal mould (GK. H 6182, pl. 9, fig. 13) $\times 3$. Paratype. Loc. Yatsushiro formation at At. 328, Bisho, Toyo Village, Kumamoto Pref. (Akatsu coll.)

Figs. 14, 15. Pachythaerus kagaharensis (Yokoyama) .............. 107

14. Rubber cast from a left internal mould (GK. H 6783, pl. 13, fig. 10) $\times 1.5$. Loc. Ishido formation at Hy. 4001, Ichinose-bashi, Nakazato village, Gumma Pref. (IchiKawa and Hayami coll.)

15. Rubber cast from a right internal mould (GK. H 6453, pl. 13, fig. 7 ) $\times 1.5$. Loc. ditto. (ICHIKAWA and HaYAMI coll.)

All specimens illustrated are kept in the Department of Geology, Kyushu University. 

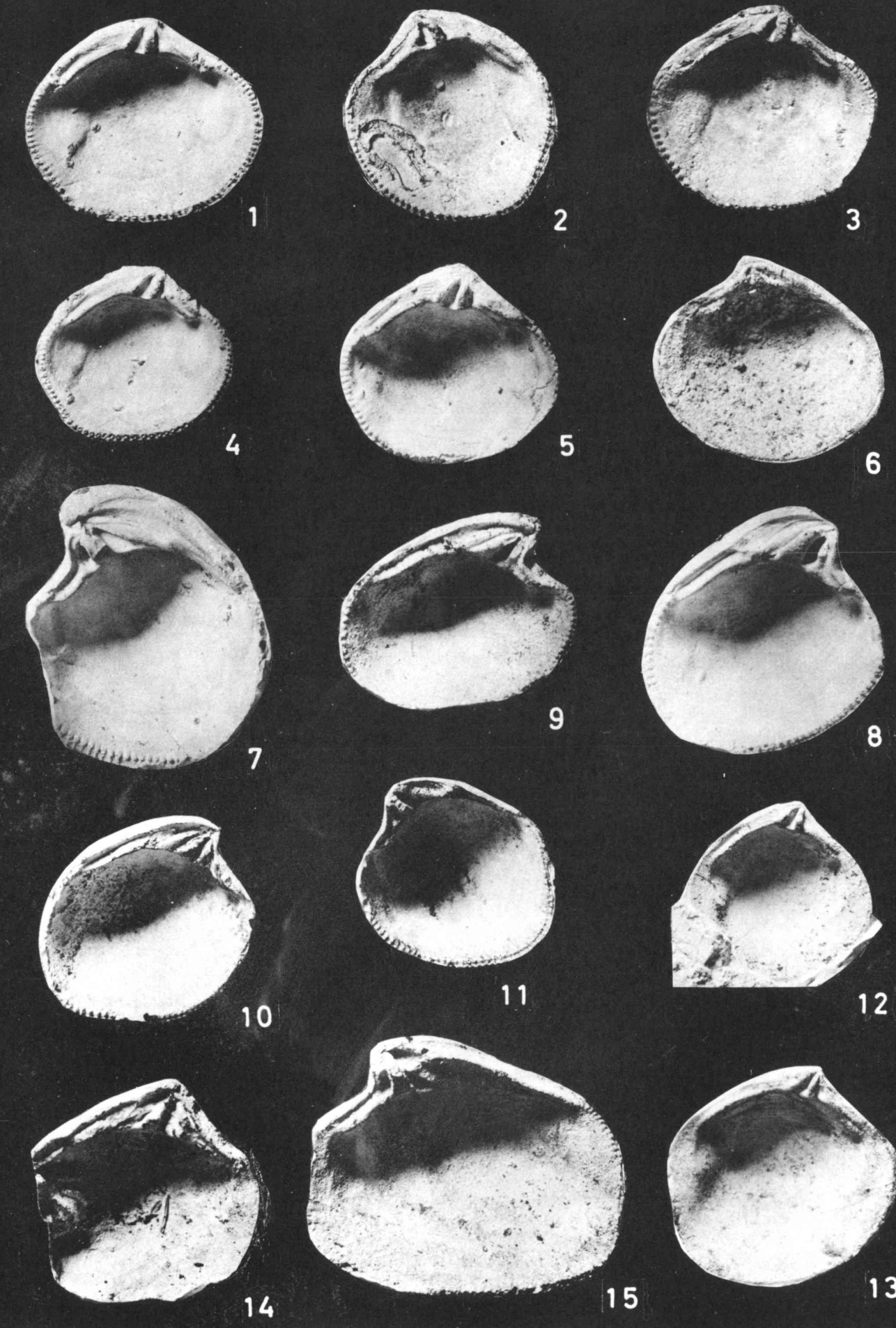

12

15

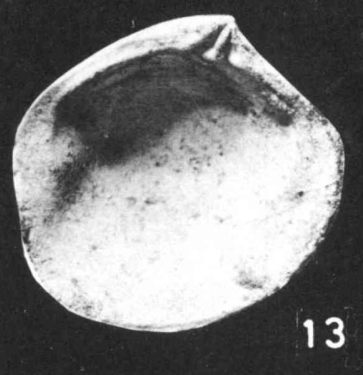

I. Hayami: Lower Cretaceous marine Pelecypods of Japan 
Plate 15 


\section{Explanation of Plate 15}

Figs. 1, 2. Pseudocardia amanoi sp. nov. ........................ 79

1. Left internal and external moulds (GK. H 6777) $\times 3$. Holotype. Loc. Hagino formation at Hy. 6011, Hagino, Mirafu village, Kochi Pref. (OGAWA coll.) 1a: internal mould; 1b: external mould; 1c: rubber cast from the same external mould.

2. Rubber cast from a left external mould (GK. H 6780) $\times 3$. Paratype. Loc. ditto. (OGAWA coll.)

Fig. 3. Lucinoma (?) sp. indet. ............................. 114

3. Rubber casts from external moulds of two valves (GK. H 6687) $\times 2$. Loc. Arita formation at Ys. 8, between Yuasa and Suhara, Yuasa town, Wakayama Pref. (Matsumoto coll.) 3a: right valve; 3b: left valve.

Figs. 4-6. Lucinoma (?) kotoi (NAGAO) ............................ 113

4. Right valve (GK. $\mathrm{H}$ 6476) $\times 2$. Loc. Hiraiga formation (boulder) at the south of Hiraiga, Tanohata village, Iwate Pref. (HANAI and HayamI coll.)

5. Right valve (GK.H 6477) $\times 2$. Loc. ditto. (HaNaI and HayaMI coll.)

6. Right valve (GK. H 6686) $\times 2$. Loc. Hiraiga formation at $\mathrm{Hn} .0018$, south of Hiraiga, the same village. (HAYAMI coll.)

Fig. 7. Fimbria sp. indet. ................................ 115

7. Left external and internal moulds (GK. H 6593) $\times 1.5$. Loc. Yatsushiro formation at $\mathrm{Km} .1843$, north of Shimofukami, Sakamoto town, Kumamoto Pref. (KANMERA coll.) 7a: fragmentary external mould; 7b: internal mould.

Figs. 8-10. Protocardia hiraigensis sp. nov. ...................... 119

8. Right valve (GK. H 6484) $\times 2$. Paratype. Loc. Hiraiga formation at Hn. 0017, south of Hiraiga, Tanohata village, Iwate Pref. (Hayami coll.)

9. Left valve (GK. H 6483) $\times 2$. Holotype. Loc. ditto. (HaYamI coll.)

10. Right internal mould (GK. H 6485) $\times 2$. Paratype. Loc. ditto. (HAYAMI coll.)

Fig. 11. Laevicardium (?) corpulentum (AmaNo) ................... 125

11. Left internal mould (GK. $\mathrm{H} 6696) \times 1.5$. Loc. Hagino formation at $\mathrm{Hy}$. 6011, Hagino, Mirafu village, Kochi Pref. (OGAWA coll.)

All specimens illustrated are kept in the Department of Geology, Kyushu University. 

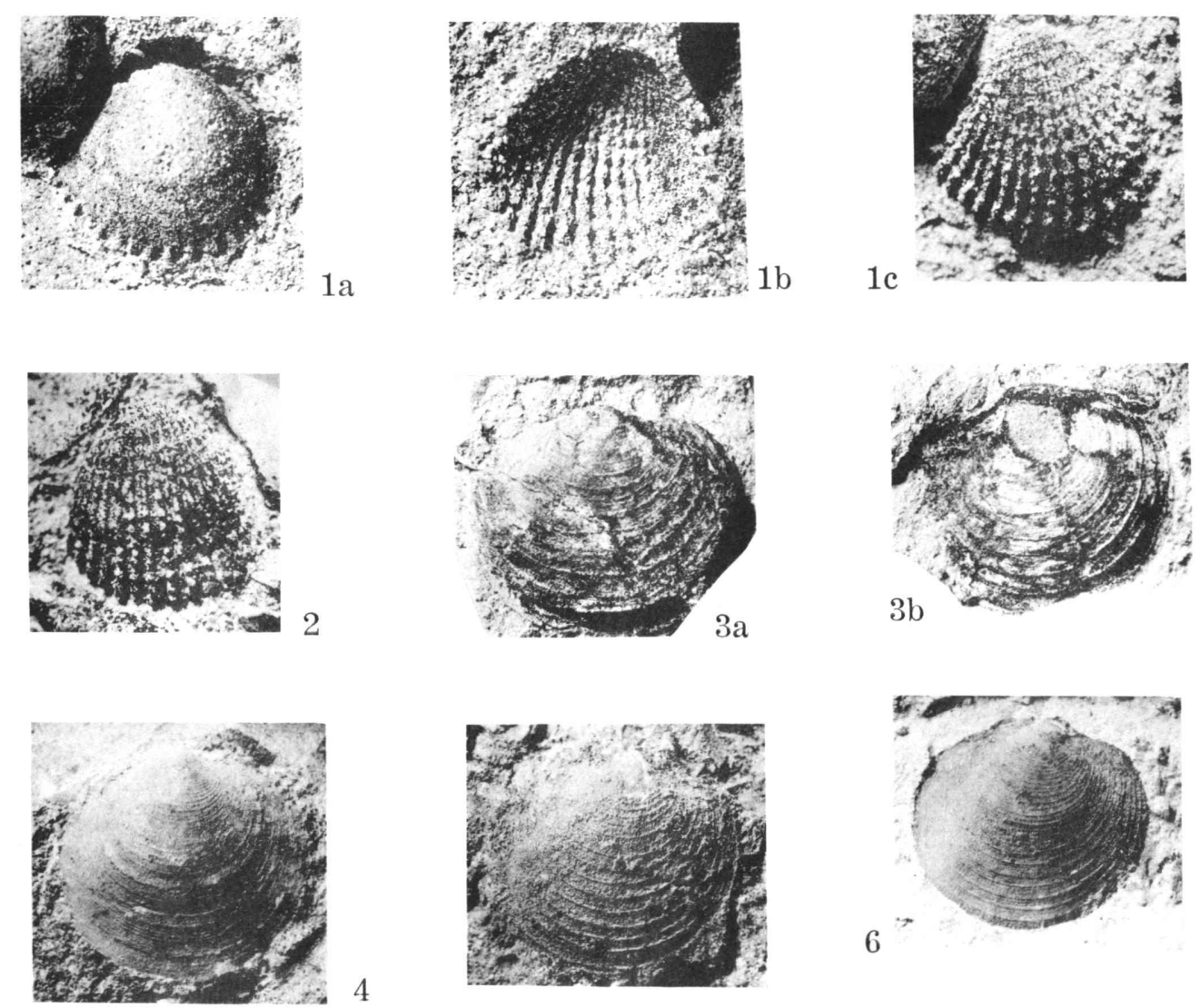

5
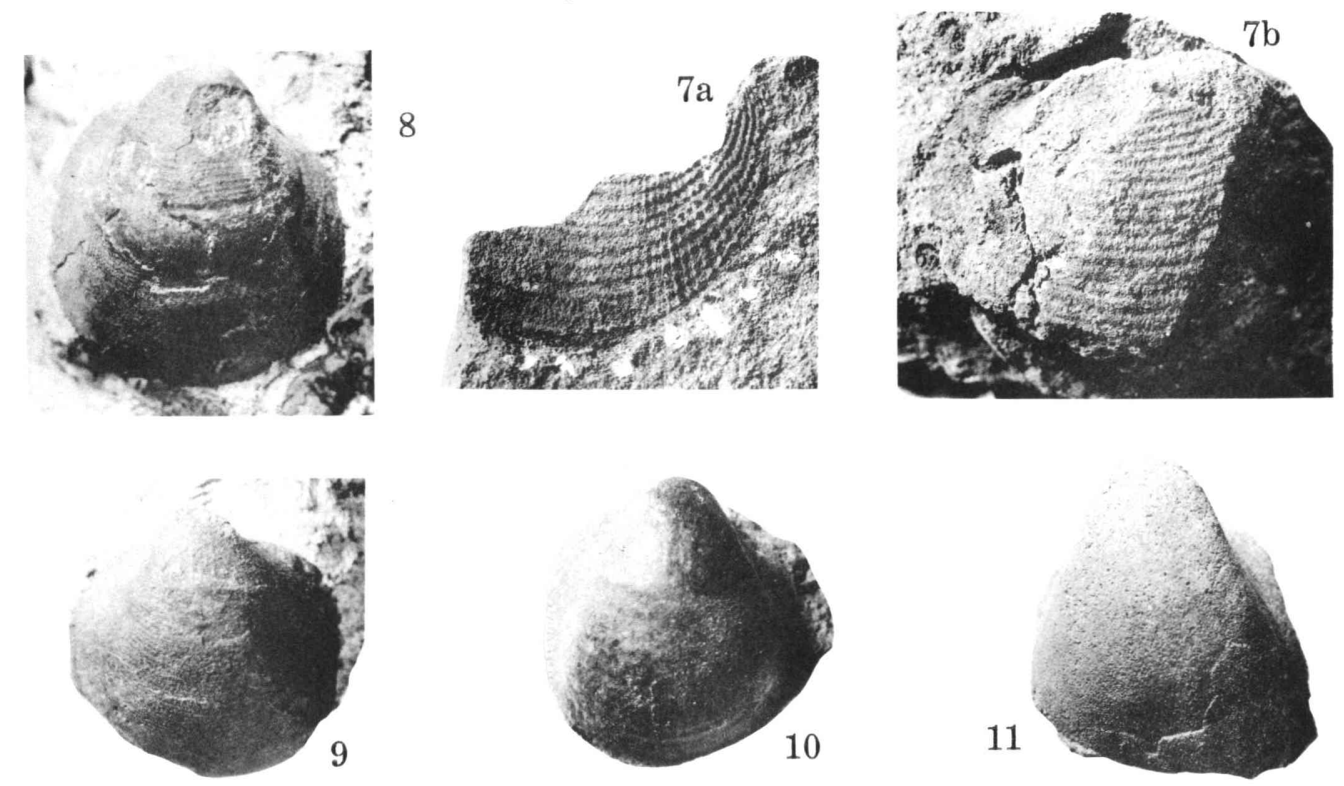

I. Hayami : Lower Cretaceous marine Pelecypods of Japan 
Plate 16 


\section{Explanation of Plate 16}

Figs. 1-6. Protocardia (Globocardium) sphaeroidea (FoRBES) ....Page 117

1. Both valves (GK. H 6689) $\times 1$. Loc. Tanohata formation at Hn. 0220, north of Hiraiga, Tanohata village, lwate Pref. (HANaI and Hayami coll.) 1a: left valve; $1 \mathrm{~b}$ : right valve; $1 \mathrm{c}$ : upper view.

2. Right valve (GK. H 6478) $\times 1$. Loc. Hiraiga formation at Hn. 0001, south of Hiraiga, the same village. (HANAI coll.) 2a: lateral view; $2 \mathrm{~b}$ : upper view.

3. Right valve (GK. H 6479) $\times 1$. Loc. Hiraiga formation at Hn. 0017, south of Hiraiga, the same village (HAYAMr coll.)

4. Right valve (GK. H 6481) $\times 1$. Loc. Tanohata formation at Hn. 0220, north of Hiraiga, the same village. (HANAI and HAYAMI coll.)

5. Right valve (GK. H 6480) $\times 1$. Loc. Hiraiga formation at Hn. 0017, south of Hiraiga, the same village. (HAYAMI coll.)

6. Right internal mould (GK. H 6688) $\times 1$. Loc. ditto. (HANAI and HaYAMI coll.)

All specimens illustrated are kept in the Department of Geology, Kyushu University. 

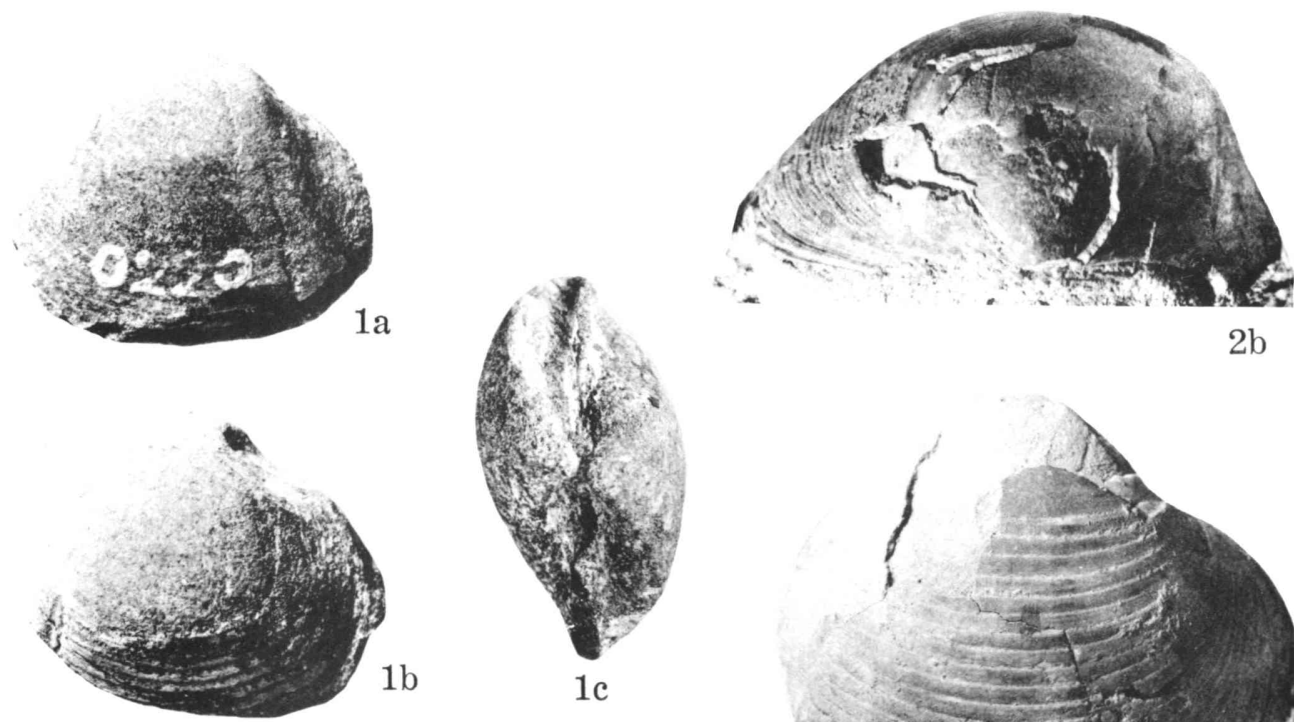

$1 \mathrm{~b} \quad 1 \mathrm{c}$

$2 b$
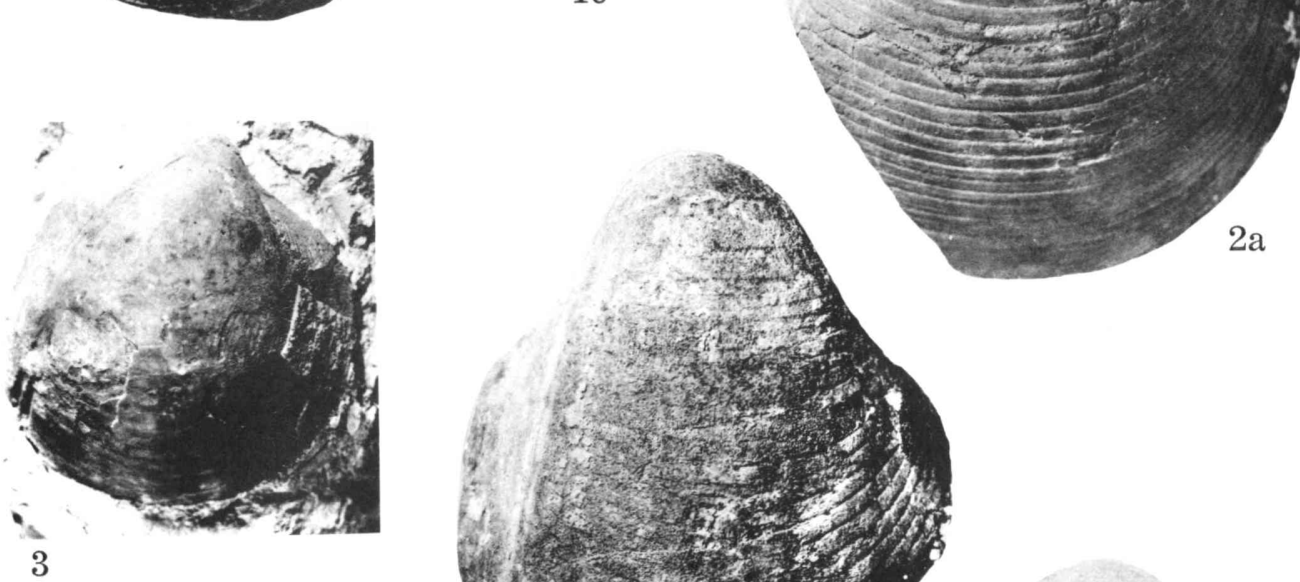

3
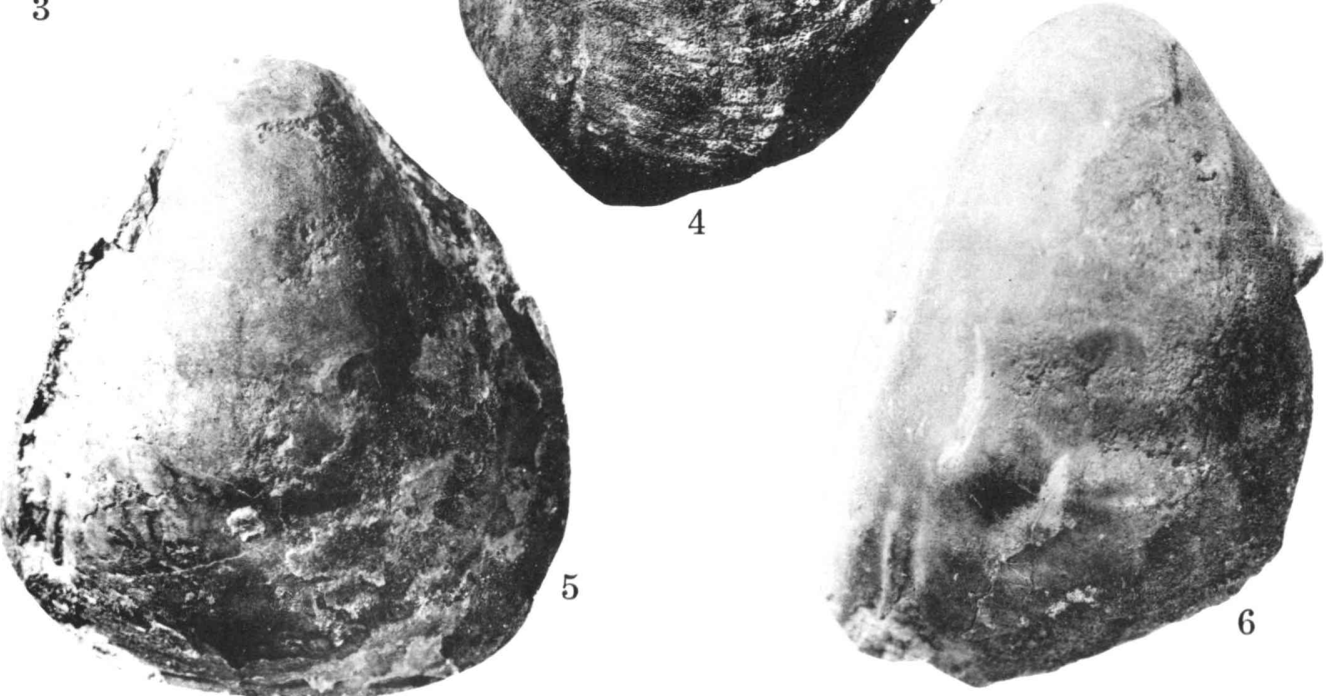

I. HAYAmI: Lower Cretaceous marine Pelecypods of Japan 
Plate 17 


\section{Explanation of Plate 17}

Figs. 1-7. Nemocardium yatsushiroense sp. nov. .................. 120

1. Right internal mould (GK. H 6486) $\times 1$. Holotype. Loc. Yatsushiro formation at Hy. 1012, Nekodani, Yatsushiro City. (HAYAMI coll.)

2. Slab with two specimens. Paratypes. Loc. Yatsushiro formation (boulder) at Kamimiya-dani, Miyaji, Yatsushiro City. (KANMera coll.) upper: left valve (GK. H 6694); lower: right valve (GK. H 6693).

3. Right valve (GK. H 6487) $\times 1$. Paratype. Loc. Yatsushiro formation at Hy. 1012, Nekodani, the same city. (HAYAMI coll.)

4. Left valve (GK. H 6488) $\times 1$. Paratype. Loc. ditto. (Hayami coll.)

5. Plaster cast from a left external mould (GK. H 6691) $\times 1$. Paratype. Loc. ditto. (HAYAMI coll.)

6. Left valve (GK. H 6690) $\times 1$. Paratype. Loc. ditto. (HAYAMI coll.)

7. Ornamentation on the central part of a right valve (GK. H 6487) $\times 5$. (same specimen as fig. 3 )

Figs. 8-10. Laevicardium (?) ishidoense (YABE and NAGAO) .......Page 123

8. Right internal mould $($ GK. H 6188) $\times 2$. Loc. Yatsushiro formation at $\mathrm{Km} .1843$, north of Shimofukami, Sakamoto town, Kumamoto Pref. (KANMERA coll.)

9. Left internal mould (GK. H 6192) $\times 2$. Loc. ditto. (KANMERA coll.)

10. Left valve (GK. H 6191) $\times 1$. Loc. Yatsushiro formation at At. 828A, Bisho, Toyo village, Kumamoto Pref. (Akatsu coll.)

All specimens illustrated are kept in the Department of Geology, Kyushu University. 

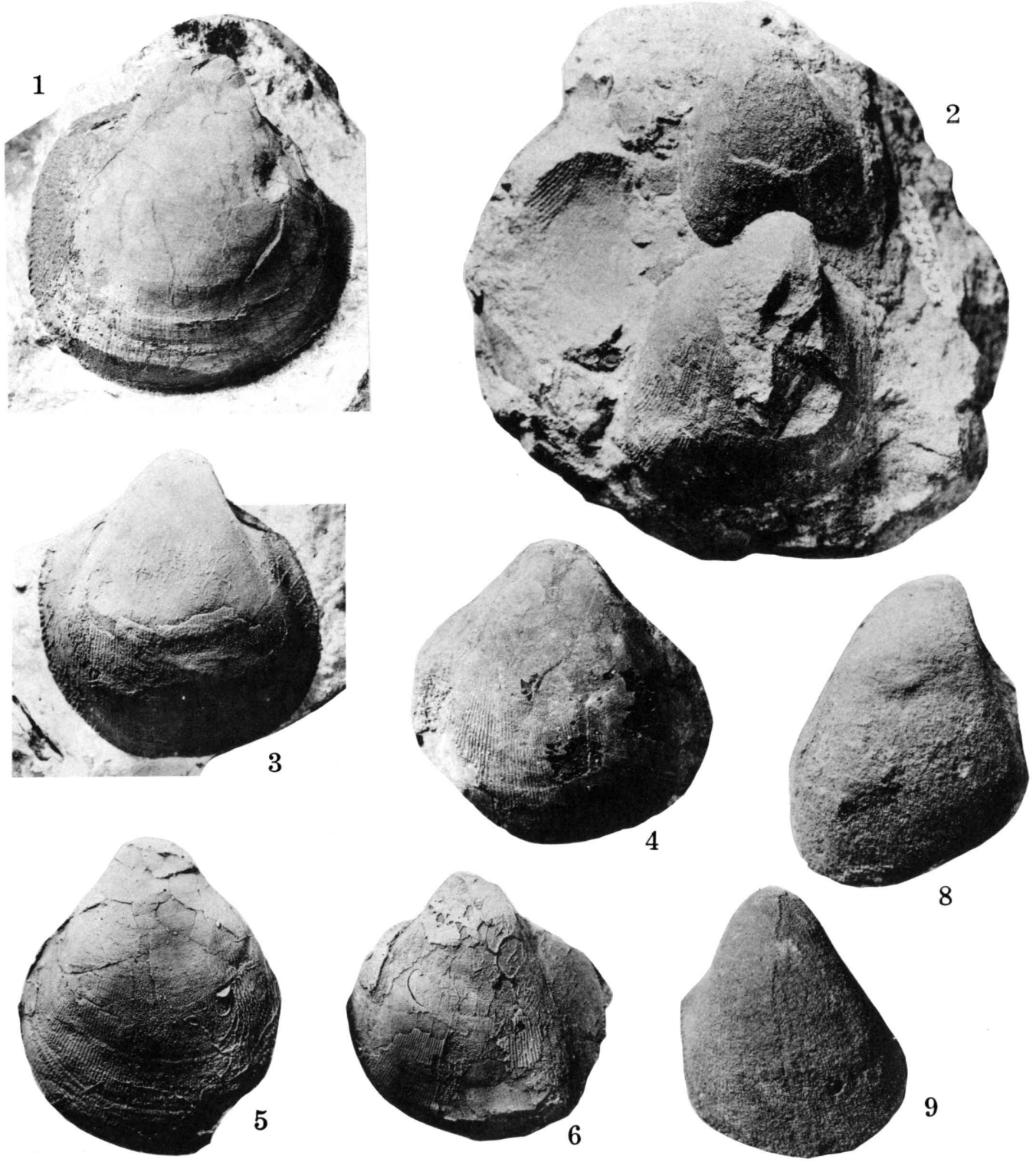

7
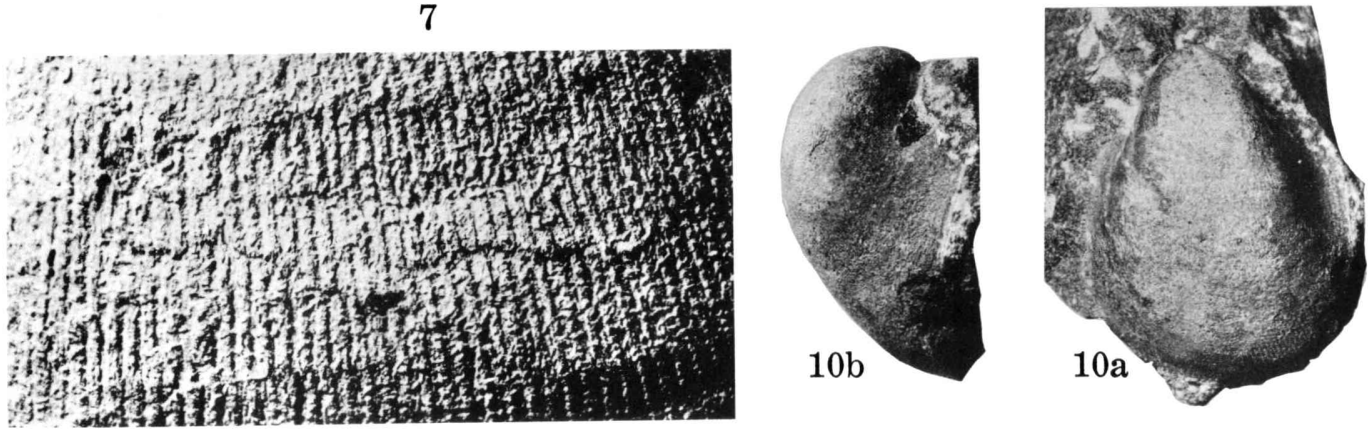

I. HAYAmI: Lower Cretaceous marine Pelecypods of Japan 
Plate 18 


\section{Explanation of Plate 18}

Fig. 1. Scittila japonica sp. nov. ......................... 126

1. Both valves $($ GK. $\mathrm{H} 6533) \times 1.5$. Holotype. Loc. Hanoura formation at Hy. 5003, Hiroyasu, Katsuura town, Tokushima Pref. (Hayami coll.) $1 \mathrm{a}$ : left valve; $1 \mathrm{~b}$ : right valve.

Figs. 2-12. Costocyrena matsumotoi sp. nov. ...................... 133

2. Right internal mould (2a) and its rubber cast (2b) (GK. H 6503) $\times \mathbf{1 . 5}$. Paratype. Loc. Yatsushiro formation at Hy. 1017, Miyaji, Yatsushiro City. (Hayamr coll.)

3. Rubber cast from a right external mould (GK. H 6502) $\times 1.5$. Holotype. Loc. ditto. (HAYAMI coll.)

4. Right internal mould (4a) and its rubber cast (4b) (GK. H 6505) $\times 1.5$. Paratype. Loc. ditto. (HAYAMI coll.)

5. Left internal mould (5a) and its rubber cast (5b) (GK. H 6507) $\times 1.5$. Paratype. Loc. ditto. (HAYAMI coll.)

6. Right internal mould (6a) and its rubber cast (6b) (GK. H 6504) $\times \mathbf{1 . 5}$. Paratype. Loc. ditto. (HAYAMI coll.)

7. Rubber cast from a left external mould (GK. H 6676) $\times 1.5$. Paratype. Loc. ditto. (HAYAMI coll.)

8. Rubber cast from a right external mould (GK. H 6798) $\times 1.5$. Paratype. Loc. ditto. (HAYAMI coll.)

9. Rubber cast from a left external mould (GK. H 6506) $\times 1.5$. Paratype. Loc. ditto. (HAYAMI coll.)

10. Rubber cast from a right external mould (GK. H 6673) $\times 1.5$. Paratype. Loc. ditto. (HAYAMI coll.)

11. Right internal mould (GK. H 6674) $\times$ 1.5. Paratype. Loc. ditto. (HayamI coll.)

12. Ornamentation on the central part of a right valve (rubber cast) (GK. $\mathrm{H}$ $6679) \times 3$. Paratype. Loc. ditto. (Hayami coll.)

Figs. 13-15. Costocyrena sp. aff. C. radiatostriata (YABE and NAGAO) ....

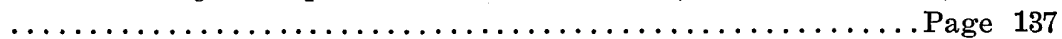

13. Right internal mould (GK. H 6684) $\times 1.5$. Loc. Izeki formation at $Y_{s}$. 1021, Yoshikawa, Kanaya town, Wakayama Pref. (Матsumoto coll.)

14. Right internal mould (GK. H 6682) $\times 1.5$. Loc. ditto. (Matsumoto coll.)

15. Plaster cast from a left external mould (GK. H 6681) $\times 1.5$. Loc. ditto. (MATSUMOTo coll.)

All specimens illustrated are kept in the Department of Geology, Kyushu University. 


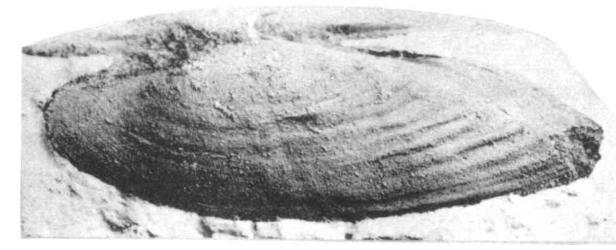

$1 \mathrm{a}$

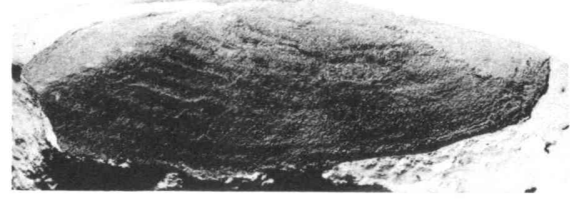

$1 b$

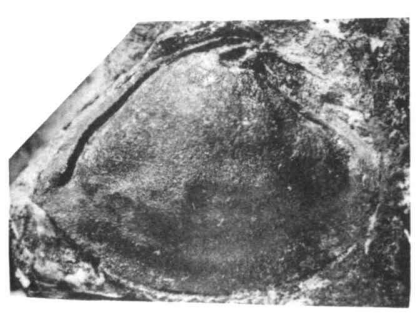

$2 \mathrm{a}$

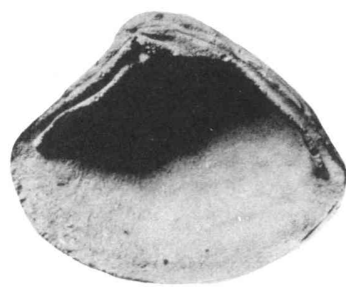

$2 \mathrm{~b}$
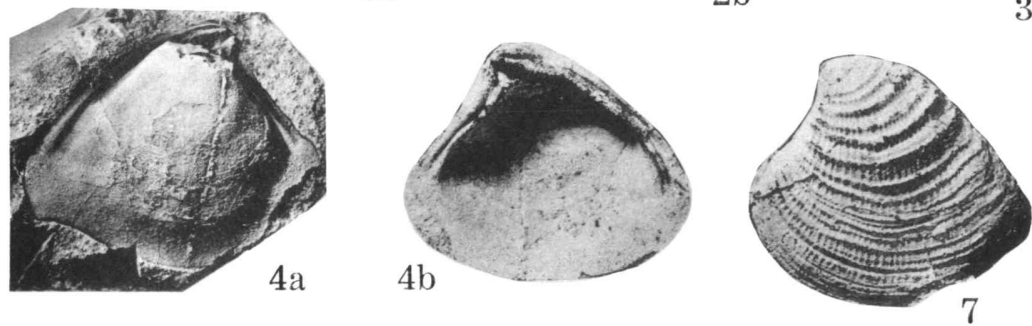

3
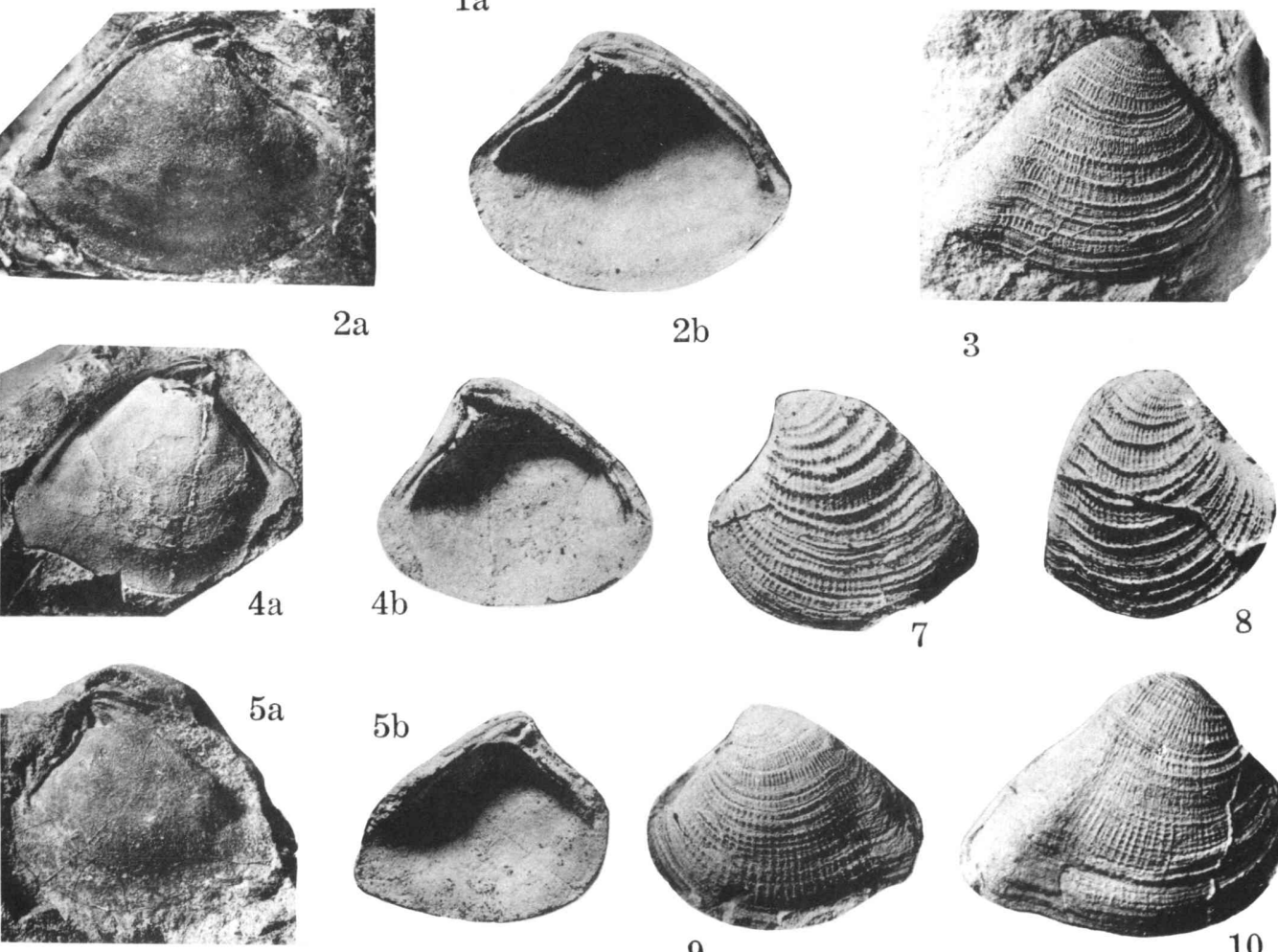

9
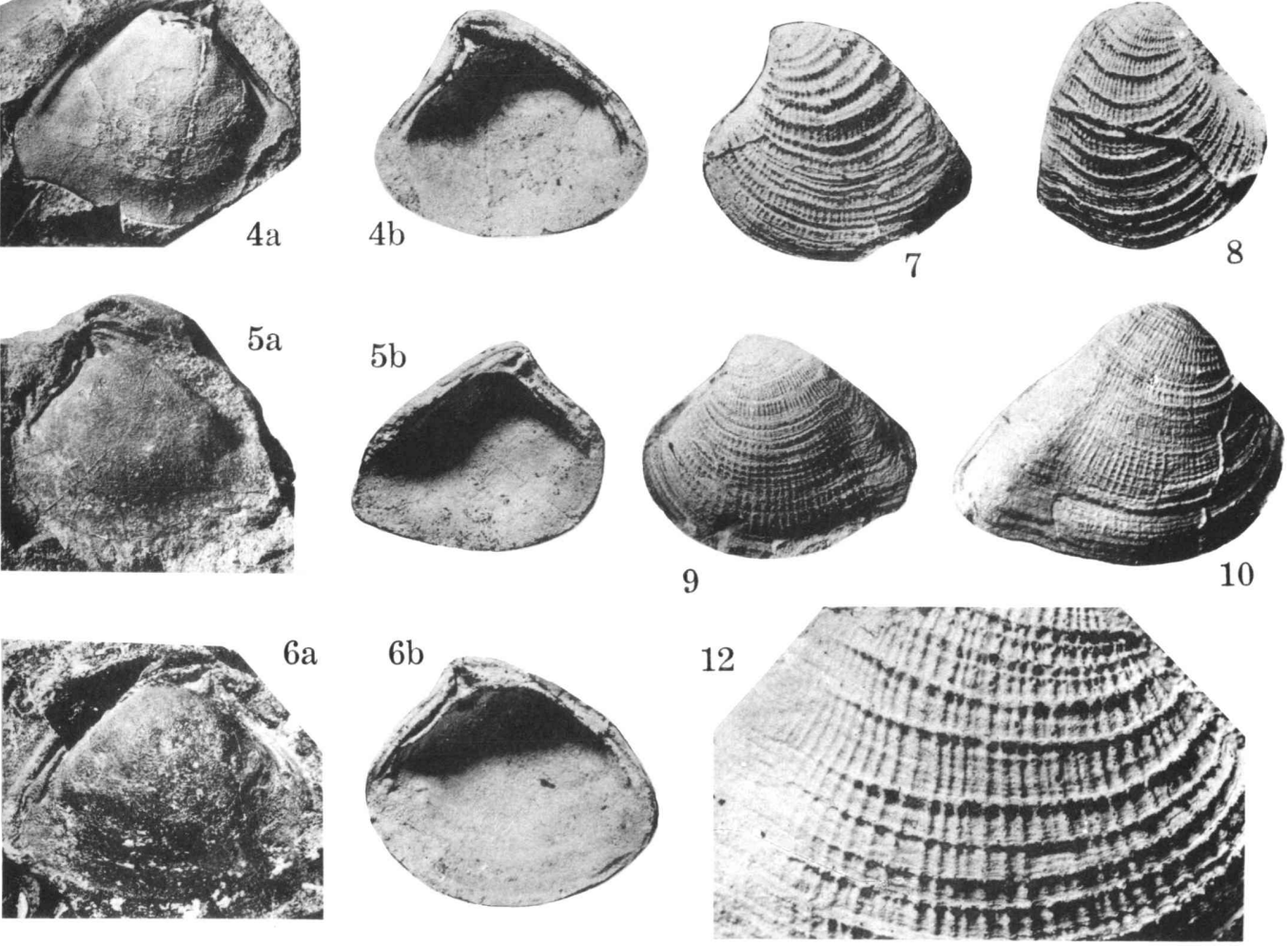

11
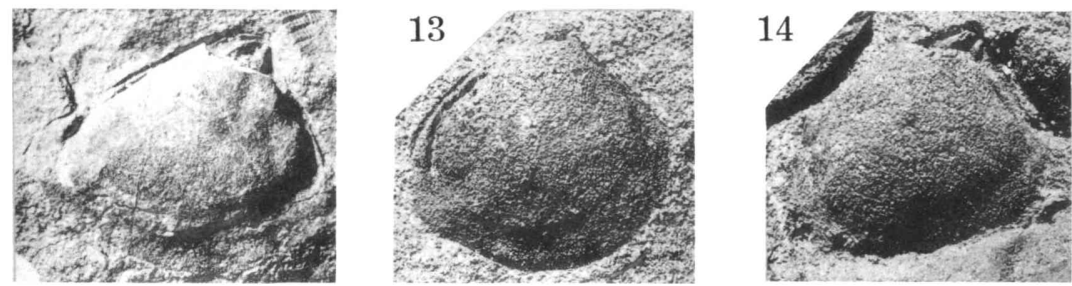

15

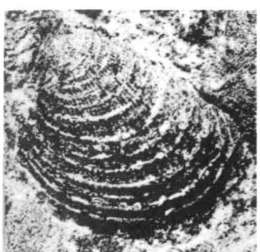

I. Hayami: Lower Cretaceous marine Pelecypods of Japan 
Plate 19 


\section{Explanation of Plate 19}

Figs. 1-7. Costocyrena radiatostriata (YABE and NAGAO) .........Page 135

1. Right internal mould (1a) and its rubber cast (1b) (GK. H 6497) $\times 1.5$. Loc. Sebayashi formation at Hy. 4005, Hachimanzawa, Nakazato village, Gumma Pref. (ICHIKAWA and HAYAMr coll.)

2. Left internal mould (2a) and its rubber cast (2b) (GK. H 6498) $\times 1.5$. Loc. ditto. (ICHIKAWA and HAYAMI coll.)

3. Right internal mould (3a) and its rubber cast (3b) (GK. H 6496) $\times 1.5$. Loc. ditto. (Ichikawa and Hayami coll.)

4. Right internal mould (GK. H 6499) $\times 1.5$. Loc. ditto. (ICHIKAWA and HAYAMI coll.)

5. Left valve (GK. H 6500) $\times 1.5$. Loc. ditto. (IchiKaWA and HaYAMI coll.)

6. Right valve (GK. H 6501) $\times 1.5$. Loc. ditto. (ICHIKAWA and HAYAMI coll.)

7. Right valve (GK. H 6502) $\times 1.5$. Loc. ditto. (IchIKAWA and HaYAMI coll.)

Figs. 8, 9. Isocyprina aliquantula (Amano) ..................... 137

8. Right internal mould (8a) and its rubber cast (8b) (GK. H 6597) $\times 2$. Loc. Hagino formation at Hy. 6011, Hagino, Mirafu village, Kochi Pref. (OGAWA coll.)

9. Rubber cast from a right external mould (GK. H 6598) $\times 2$. Loc. ditto. (OGAWA coll.)

Fig. 10. Veniella sp. aff. V. japonica NAGAo ....................... 139

10. Left internal mould (GK. $\mathrm{H} 6596) \times 1.5$. Loc. Yatsushiro formation at $\mathrm{Km}$. 3151, Miyaji, Yatsushiro City. (KanMera coll.)

Fig. 11. Scittila sp. indet. ................................ 127

11. Right valve (GK. $\mathrm{H} 6710$ ) $\times 1.5$. Loc. Hanoura formation at Hy. 5001, Hiroyasu, Katsuura town, Tokushima Pref. (HAYAMI coll.)

Figs. 12-15. Nagaoella corrugata (NAGA0) ....................... 148

12. Right valve (GK. H 6709) $\times 2$. Loc. Hiraiga formation at Hn. 1904, the south of Haipe, Tanohata village, Iwate Pref. (HanaI and Hayami coll.)

13. Left valve (GK. $\mathrm{H} 6708) \times 2$. Loc. ditto. (HANAI and Hayami coll.)

14. Right valve (GK. H 6700) $\times 1$. (14a), $\times 2$ (14b). Loc. Hiraiga formation (boulder) at the north of Haipe, the same village (HANAI and HAYAMI coll.)

15. Subinternal radial ornamentation on the ventral part of a right valve (GK. H 6516, pl. 14, fig. 2) $\times 5$. Loc. Hiraiga formation at Hn. 0018, south of Hiraiga, the same village. (HAYAMI coll.)

All specimens illustrated are kept in the Department of Geology, Kyushu University. 


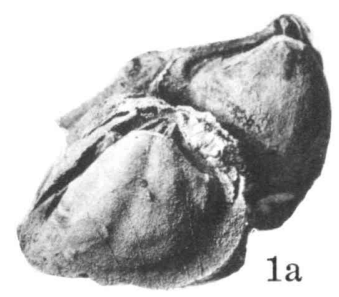

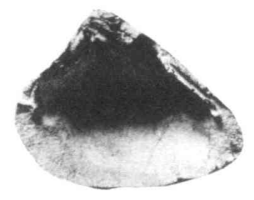

$1 \mathrm{~b}$

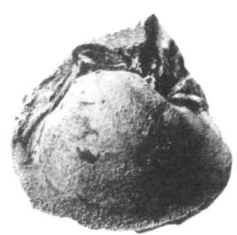

$2 a$

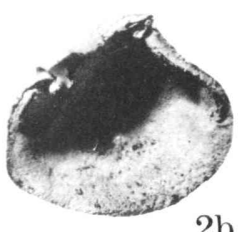

$2 b$
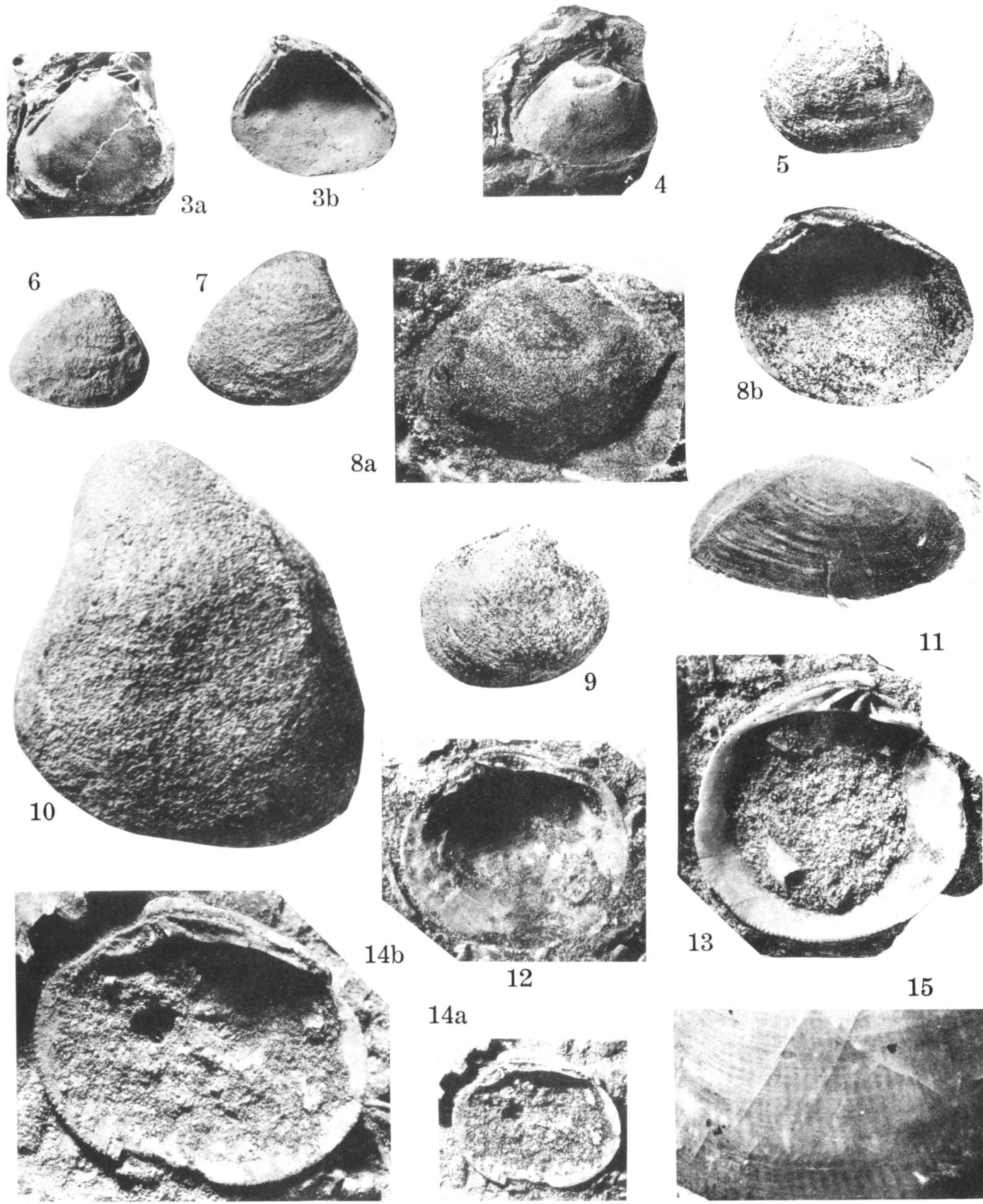

$14 \mathrm{a}$
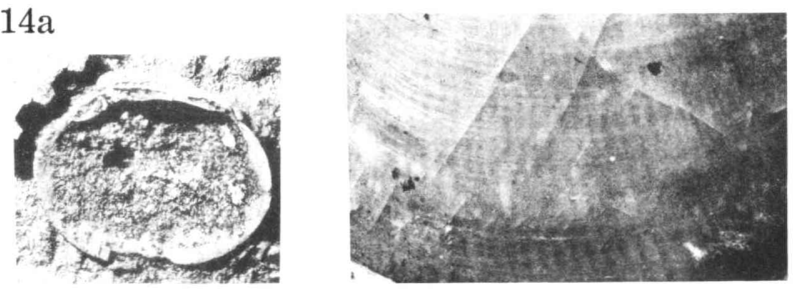

I. Hayami: Lower Cretaceous marine Pelecypods of Japan 
Plate 20 


\section{Explanation of Plate 20}

Figs. 1-12. Nagaoella corrugata (NAGA0) ........................ 148

1. Right valve (GK. H 6799) $\times 2$. Loc. Hiraiga formation at Hn. 1904, south of Haipe, Tanohata village, Iwate Pref. (HANAI coll.)

2. Right valve (GK. H 6516). Loc. Hiraiga formation at $\mathrm{Hn} .0018$, south of Hiraiga, the same village (HAYAMI coll.) 2a: lateral view $(\times 2)$; $2 \mathrm{~b}$ : upper view $(\times 1.5)$.

3. Right valve (GK. H 6507) $\times 2$. Loc. ditto. (HAYAMI coll.)

4. Right valve (GK. H 6703) $\times 2$. Loc. ditto. (HAYAMI coll.)

5. Right valve (GK. H 6518) $\times 2$. Loc ditto. (HAYAMI coll.)

6. Left valve (GK. H 6520) $\times 2$. Loc. ditto. (HANAI and Hayami coll.)

7. Right valve (GK. H 6517) $\times 2$. Loc. ditto. (HANAI and Hayami coll.)

8. Left valve (GK. H.6702) $\times 2$. Loc. ditto. (HAYAMI coll.)

9. Left valve (GK. H 6521) $\times 2$. Loc. ditto. (HANAI and HaYami coll.)

10. Left valve (GK. H 6519) $\times 2$. Loc. Hiraiga formation at Hn. 0017, south of Hiraiga, the same village (HANAI and HAYAMI coll.)

11. Left valve (GK. H 6704) $\times 2$. Loc. Hiraiga formation at Hn. 0018, south of Hiraiga, the same village. (HANAI and HAYAMI coll.)

12. Right valve (GK. H 6800) $\times 1$. Loc. Hiraiga formation at Hn. 0916, north of Haipe, the same village. (HANAI and HAYAMI coll.)

Fig. 13. Nagaoella sp. aff. N. corrugata (NAGAO) ..............Page 150

13. Right valve (GK. H 6532) $\times 1$. Loc. Hiraiga formation at Hn. 0018, south of Hiraiga, the same village. (HAYAMI coll.)

Fig. 14. Agapella (?) koikorobensis sp. nov. ...................... 144

14. Left valve (GK. $\mathrm{H}$ 6495) $\times 1.5$. Holotype. Loc. Tanohata formation at Hn. 0803, Koikorobe, the same village (HAYAMI coll.)

All specimens illustrated are kept in the Department of Geology, Kyushu University. 

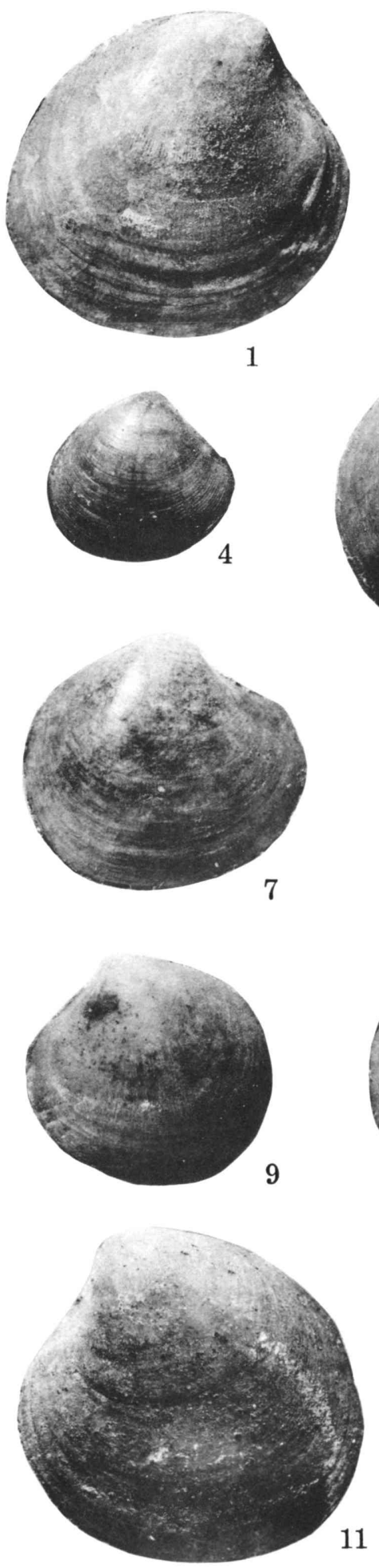

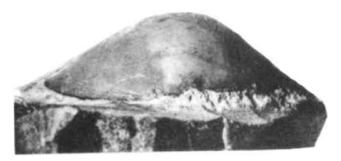

$2 \mathrm{~b}$

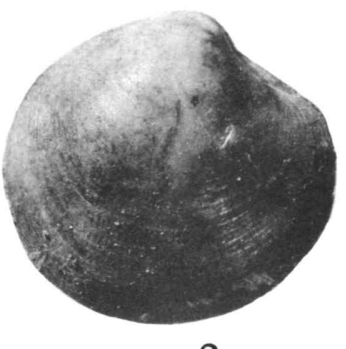

$2 \mathrm{a}$
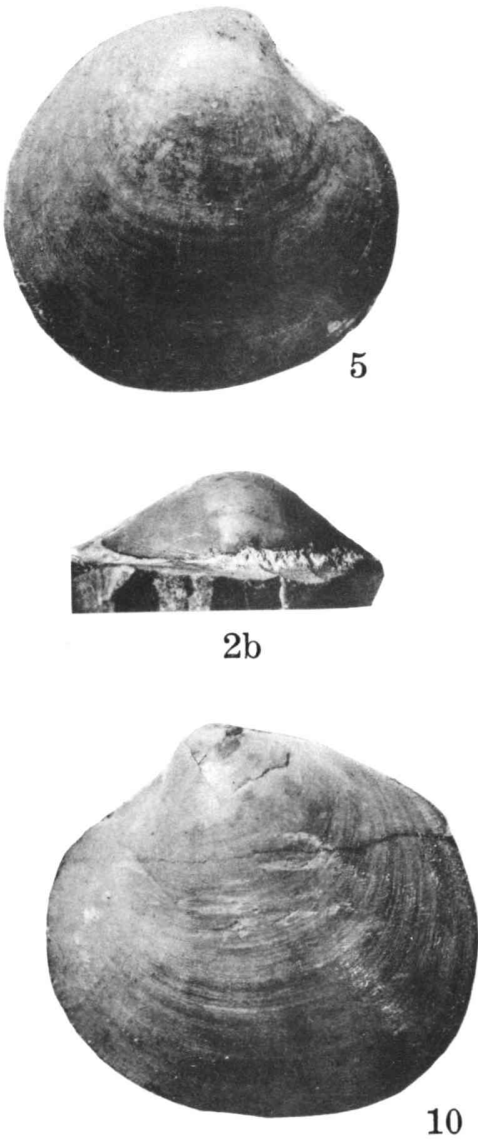

10
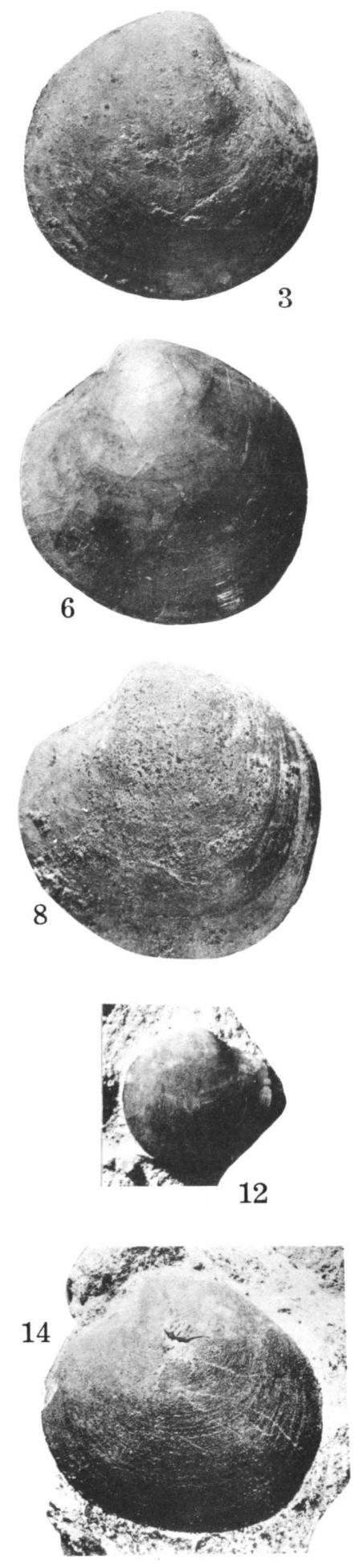

I. HAYAmi : Lower Cretaceous marine Pelecypods of Japan 
Plate 21 


\section{Explanation of Plate 21}

Figs. 1-4. Ptychomya densicostata NAGAO ......................... 141

1. Both valves (GK. H 6513) $\times 1$. Loc. Nagaiso member of the Ofunato group at Hy. 0053, Kinchakuiwa, Ofunato city. (OBAta, Tokuyama and HAYAMI coll.) 1a: right valve: $1 \mathrm{~b}$ : left valve.

2. Right internal and external moulds (GK. H 6512) $\times 1$. Loc. Arita formation at Ys. 103, west of Kumai, Yuasa town, Wakayama Pref. (MATsuмото et al. coll.) 2a: internal mould; $2 \mathrm{~b}$ : its rubber cast; 2c: external mould; $2 d$ : its rubber cast.

3. Right valve (GK. H 6699) $\times 1$. Loc. Ishido formation at Hy. 4001, Ichinose-bashi, Nakazato village, Gumma Pref. (ICHIKawa and Hayami coll.)

4. Left internal mould (GK. H 6697) $\times 1$. Loc. Arita formation at Ys. 103, west of Kumai, Yuasa town, Wakayama Pref. (Matsumoto et al. coll.)

All specimens illustrated are kept in the Department of Geology, Kyushu University. 

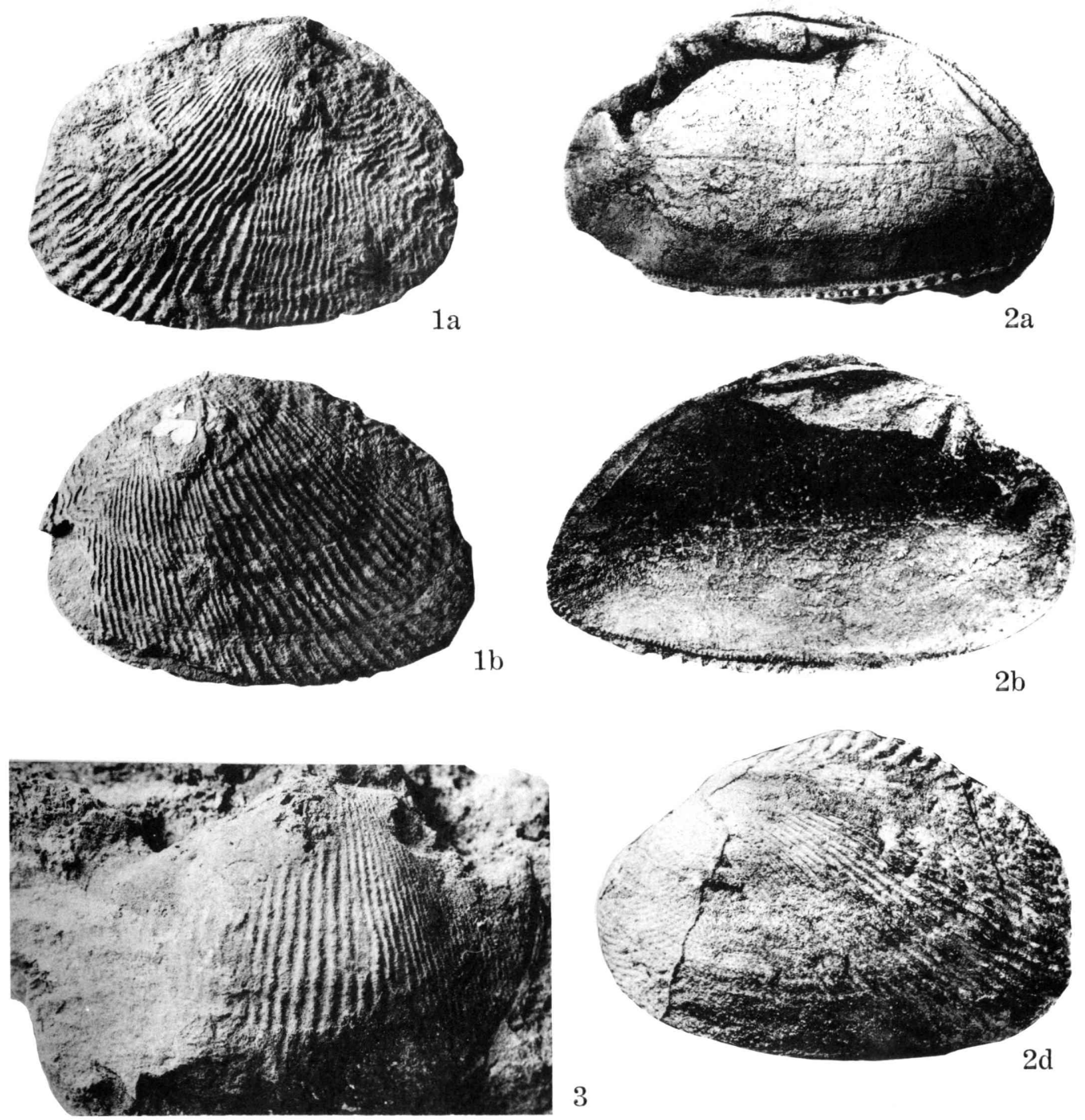

3
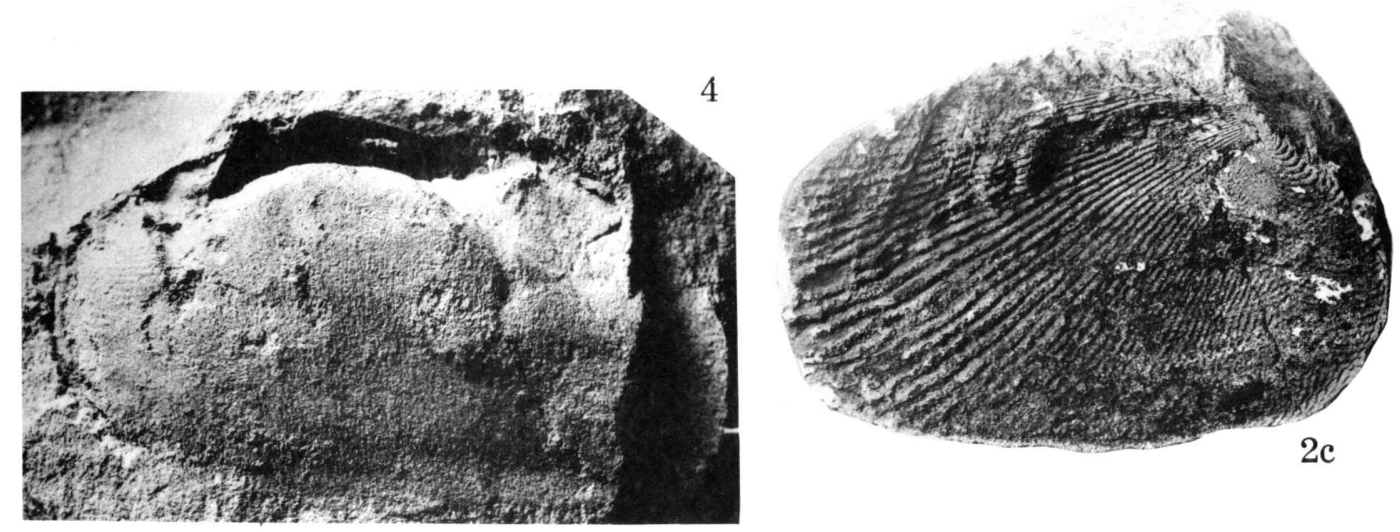

I. Hayami : Lower Cretaceous marine Pelecypods of Japan 